УДК 004.8

06.02.10 Частная зоотехния, технология производства продуктов животноводства (сельскохозяйственные науки)

КОГНИТИВНАЯ ИНФОРМАЦИОННО-
ИЗМЕРИТЕЛЬНАЯ КВАЛИМЕТРИЧЕСКАЯ
СИСТЕМА ДЛЯ ОПРЕДЕЛЕНИЯ
СОДЕРЖАНИЯ ЖИРА И БЕЛКА В
КОРОВЬЕМ МОЛОКЕ ПО ПАРАМЕТРАМ
ТЕНЗИОГРАММ ДИНАМИЧЕСКОГО
ПОВЕРХНОСТНОГО НАТЯЖЕНИЯ НА
ГРАНИЦЕ РАЗДЕЛА МОЛОКО/ВОЗДУХ

Луценко Евгений Вениаминович

д.э.н., к.т.н., профессор

Scopus Author ID: 57188763047

РИНЦ SPIN-код: 9523-7101

prof.lutsenko@gmail.com http://lc.kubagro.ru

Печурина Елена Каримовна

РИНЦ SPIN-код: 1952-4286

geskov@mail.ru

Сергеев Александр Эдуардович

к.ф.-м.н, доцент

РИНЦ SPIN-код: 7837-9566

Кубанский государственный аграрнылй университет имени И.Т.Трубилина, Краснодар, Россия

Рядом авторов (Милаёва И.В., Зайцев С.Ю., Довженко Н.А., Царьков Д.В., Царькова М.С., $2015)$ предложена регрессионная модель и способ косвенного измерения содержания жира и белка в коровьем молоке по его динамическому поверхностному натяжению, имеющий ряд преимуществ перед традиционным подходом. Эта модель отражает объективно существующие взаимосвязи между содержанием жира и белка в коровьем молоке и параметрами тензиограмм динамического поверхностного натяжения на границе раздела молоко/воздух. Эти взаимосвязи выявлены авторами способа путем математической обработки 112 эмпирических проб. Для этого ими был применен регрессионный и корреляционный анализ (в MS Excel). Так как содержание жира и белков в молоке во многом определяет его качество, то данная задача относится к задачам квалиметрии. Однако, данная задача квалиметрии относится также к типичным задачам распознавания образов (многопараметрической типизации и системной идентификации), и, поэтому вполне возможно, что качество ее решения может быть повышено путем применения методов искусственного интеллекта, в частности когнитивных и информационных технологий. Тем более, что эти взаимосвязи имеют довольно сложный характер. Применение интеллектуальных технологий открывает также дополнительные
UDC 004.8

Private zootechnnics, technology of production of animal husbandry products (agricultural sciences)

\section{COGNITIVE INFORMATION-MEASURING SYSTEM FOR QUALITATIVE DETERMINATION OF FAT AND PROTEIN IN COW'S MILK IN THE PARAMETERS OF CENTIGRAMS OF DYNAMIC SURFACE TENSION AT THE INTERFACE OF MILK/AIR}

\author{
Lutsenko Evgeniy Veniaminovich \\ Dr.Sci.Econ., Cand.Tech.Sci., professor \\ Scopus Author ID: 57188763047 \\ RSCI SPIN-code: 9523-7101 \\ prof.lutsenko@gmail.com http://lc.kubagro.ru
}

Pechurina Elena Karimovna

RSCI SPIN-code: 1952-4286

geskov@mail.ru

Sergeev Aleksandr Eduardovich

Cand.Phys.-Math.Sci., associate Professor

RSCI SPIN-code: 7837-9566

Kuban State Agrarian University named after

I.T.Trubilin, Krasnodar, Russia

A number of authors (Milaeva I. V., Zaitsev S. Yu., Dovzhenko N. A., Tsarkov D. V., Tsarkova M. S., 2015) have proposed a regression model and a method for indirect measurement of fat and protein content in cow's milk by its dynamic surface tension, which has a number of advantages over the traditional approach. The model reflects the objectively existing relations between the content of fat and protein in cow's milk and parameters of centigrams of dynamic surface tension at the interface of the milk/air. These relationships are revealed by the authors of the method wit mathematical processing of 112 empirical samples. For this purpose, they have applied regression and correlation analysis (in MS Excel). Since the content of fat and proteins in milk largely determines its quality, this problem refers to the problems of qualimetry. However, this problem of qualimetry also refers to typical problems of pattern recognition (multi-parameter typing and system identification), and therefore it is possible that the quality of its solution can be improved by the use of artificial intelligence methods, in particular cognitive and information technologies. Moreover, these relationships are quite complex. The use of intelligent technologies also creates additional opportunities for the study of the simulated subject area by studying its model. All this is of great scientific and practical interest for both researchers and practitioners. To solve all these problems in the work we have applied 
возможности для исследования моделируемой предметной области путем исследования ее модели. Все это представляет большой научный и практический интерес как для ученых исследователей, а так и для практиков. Для решения всех этих задач в работе применен Автоматизированный системно-когнитивный анализ (АСК-анализ) и его программный инструментарий - интеллектуальная система «Эйдос». Подробно рассмотрен численный пример, основанный на реальных данных

КЛЮЧЕВЫЕ СЛОВА: АСК-АНАЛИЗ, АВТОМАТИЗИРОВАННЫЙ СИСТЕМНОКОГНИТИВНЫЙ АНАЛИЗ, СИСТЕМА «ЭЙДОС», КВАЛИМЕТРИЯ, МОЛОКО, ЖИР, БЕЛОК, ИЗМЕРЕНИЕ, ДИНАМИЧЕСКОЕ ПОВЕРХНОСТНОЕ НАТЯЖЕНИЕ
Automated System-Cognitive analysis (ASC-analysis) and its software tool which is an intelligent system called "Eidos". A numerical example based on real data has been considered in detail as well

\section{СОДЕРЖАНИЕ}

ВВЕДЕНИЕ

Keywords: ASC-ANALYSIS, AUTOMATED SYSTEM-COGNITIVE ANALYSIS, "EIDOS" SYSTEM, QUALIMETRY, MILK, FAT, PROTEIN, MEASUREMENT, DYNAMIC SURFACE TENSION

ЗАДАЧА 1: КОГНИТИВНАЯ СТРУКТУРИЗАЦИЯ ПРЕДМЕТНОЙ ОБЛАСТИ.

\section{ЗАДАЧА 2: ПОДГОТОВКА ИСХОДНЫХ ДАННЫХ И ФОРМАЛИЗАЦИЯ ПРЕДМЕТНОЙ} ОБЛАСТИ 8

ЗАДАЧА 3: СИНТЕЗ И ВЕРИФИКАЦИЯ СТАТИСТИЧЕСКИХ И СИСТЕМНО-КОГНИТИВНЫХ МОДЕЛЕЙ И ВЫБОР НАИБОЛЕЕ ДОСТОВЕРНОЙ ИЗ НИХ ДЛЯ РЕШЕНИЯ ЗАДАЧ .............. 14

ЗАДАЧА 4: РЕШЕНИЕ РАЗЛИЧНЫХ ЗАДАЧ В НАИБОЛЕЕ ДОСТОВЕРНОЙ МОДЕЛИ........... 20

ПОДЗАДАЧА 4.1. ПРОГНОЗИРОВАНИЕ (ДИАГНОСТИКА, КЛАССИФИКАЦИЯ, РАСПОЗНАВАНИЕ, ИДЕНТИФИКАЦИЯ)

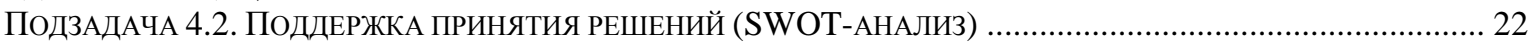

ПОДЗАДАЧА 4.3. ИССЛЕДОВАНИЕ МОДЕЛИРУЕМОЙ ПРЕДМЕТНОЙ ОБЛАСТИ ПУТЕМ ИССЛЕДОВАНИЯ ЕЕ

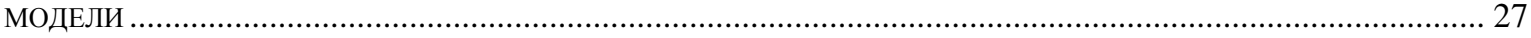

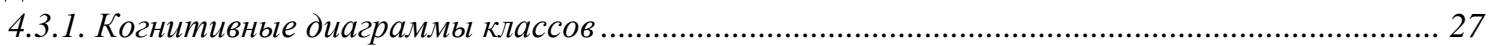

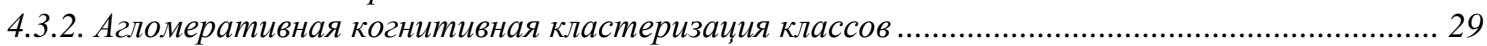

4.3.3. Когнитивные диаграммы значений факторов..................................................................... 30

4.3.4. Агломеративная когнитивная кластеризаџия значений факторов..................................... 32

4.3.5. Нелокальные нейроны и нелокальные нейронные сети .......................................................... 33

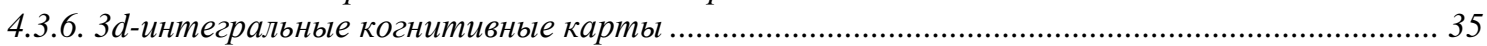

4.3.7. Когнитивные функиии ............................................................................................................. 35

4.3.8. Сила и направление влияния значений параметров ДПН и сила влияния самих параметров ДПН на содержание жира и белка в коровьем молоке ................................................................... 44

4.3.9. Степень детерминированности качества молока значениями параметров ДПН................ 47 4.3.10. Устойчивость содержания жира и белка в коровьем молоке от значений параметров ДПН......

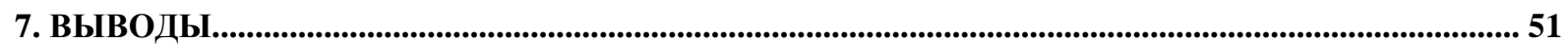

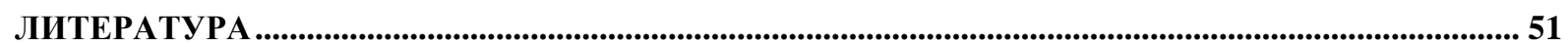




\section{Введение}

Рядом авторов (Милаёва И.В., Зайцев С.Ю., Довженко Н.А., Царьков Д.В., Царькова М.С., 2015) [1-6] предложена регрессионная модель и способ косвенного измерения содержания жира и белка в коровьем молоке по его динамическому поверхностному натяжению, имеющий ряд преимуществ перед традиционным подходом.

Эта модель на определенном уровне адекватности отражает объективно существующие причинно-следственные взаимосвязи между содержанием жира и белка в коровьем молоке и параметрами тензиограмм динамического поверхностного натяжения (ДПН) на границе раздела молоко/воздух. Эти взаимосвязи выявлены авторами способа путем математической обработки 112 эмпирических проб. Для этого ими был применен регрессионный и корреляционный анализ (в MS Excel).

Так как содержание жира и белков в молоке во многом определяет его качество, то данная задача относится к задачам квалиметрии.

Однако проблема состоит в том, что сама зависимость содержания жира и белка в молоке от параметров ДПН имеет довольно сложный характер и ее сложно адекватно отразить в формальной модели. Но данная задача относится не только к квалиметрии, но и к типичным задачам распознавания образов (многопараметрической типизации, т.е. формирования обобщенных образов классов на основе описаний объектов, и системной идентификации объектов, т.е. определения принадлежности объектов к классам), и, поэтому возможно, что качество ее решения может быть повышено путем применения более адекватных для подобных задач методов искусственного интеллекта, в частности когнитивных и информационных технологий. Применение интеллектуальных технологий открывает также дополнительные возможности для исследования моделируемой предметной области путем исследования ее модели. Все это представляет большой научный и практический интерес как для ученых исследователей, а так и для практиков.

Поэтому целью данной работы является разработка интеллектуальных моделей, отражающих реально существующие причинно-следственные взаимосвязи между содержанием жира и белка в коровьем молоке и параметрами тензиограмм динамического поверхностного натяжения на границе раздела молоко/воздух и применение этих моделей как для косвенного измерения содержанием жира и белка в коровьем молоке, так и для исследования моделируемой предметной области.

Для достижения поставленной цели в данной работе предлагается применить Автоматизированный системно-когнитивный анализ (АСКанализ) и его программный инструментарий - интеллектуальная система «Эйдос». 
АСК-анализ предполагает, что для достижения поставленной цели необходимо решить следующие задачи, которые получаются путем декомпозиции цели и являются этапами ее достижения:

Задача 1: когнитивная структуризация предметной области.

Задача 2: подготовка исходных данных и формализация предметной области.

Задача 3: синтез и верификация статистических и системнокогнитивных моделей и выбор наиболее достоверной модели.

Задача 4: решение различных задач в наиболее достоверной модели:

- подзадача 4.1. Прогнозирование (диагностика, классификация, распознавание, идентификация);

- подзадача 4.2. Поддержка принятия решений;

- подзадача 4.3. Исследование моделируемой предметной области путем исследования ее модели (когнитивные диаграммы классов и значений факторов, агломеративная когнитивная кластеризация классов и значений факторов, нелокальные нейроны и нейронные сети, 3dинтегральные когнитивные карты, когнитивные функции и др.).

Эти задачи по сути представляют собой этапы Автоматизированного системно-когнитивный анализа (АСК-анализ), который и поэтому и предлагается применить для их решения.

АСК-анализ представляет собой метод искусственного интеллекта, разработанный проф. Е.В. Луценко в 2002 году для решения широкого класса задач идентификации, прогнозирования, классификации, диагностики, поддержки принятия решений и исследования моделируемой предметной области путем исследования ее модели. АСК-анализ доведен до инновационного уровня благодаря тому, что имеет свой программный инструментарий - универсальную когнитивную аналитическую систему «Эйдос-Х++» (система «Эйдос») [7-17].

Система «Эйдос» выгодно отличается от других интеллектуальных систем следующими параметрами:

- разработана в универсальной постановке, не зависящей от предметной области. Поэтому она является универсальной и может быть применена во многих предметных областях (http://lc.kubagro.ru/aidos/index.htm);

находится в полном открытом бесплатном доступе (http://lc.kubagro.ru/aidos/_Aidos-X.htm), причем с актуальными исходными текстами (http://lc.kubagro.ru/_AIDOS-X.txt);

- является одной из первых отечественных систем искусственного интеллекта персонального уровня, т.е. она не требует от пользователя специальной подготовки в области технологий искусственного интеллекта (есть акт внедрения системы «Эйдос» 1987 года) (http://lc.kubagro.ru/aidos/aidos02/PR-4.htm); 
- обеспечивает устойчивое выявление в сопоставимой форме силы и направления причинно-следственных зависимостей в неполных зашумленных взаимозависимых (нелинейных) данных очень большой размерности числовой и не числовой природы, измеряемых в различных типах шкал (номинальных, порядковых и числовых) и в различных единицах измерения (т.е. не предъявляет жестких требований к данным, которые невозможно выполнить, а обрабатывает те данные, которые есть);

- содержит большое количество локальных (поставляемых с инсталляцией) и облачных учебных и научных приложений (в настоящее $\begin{array}{llllll}\text { время их } & 31 & \text { и } & 154, & \text { соответственно) }\end{array}$ (http://lc.kubagro.ru/aidos/Presentation_Aidos-online.pdf);

- обеспечивает мультиязычную поддержку интерфейса на 44 языках. Языковые базы входят в инсталляцию и могут пополняться в автоматическом режиме;

- поддерживает on-line среду накопления знаний и широко используется во всем мире (http://aidos.byethost5.com/map5.php);

- наиболее трудоемкие в вычислительном отношении операции синтеза моделей и распознавания реализует с помощью графического процессора (GPU), что на некоторых задачах обеспечивает ускорение решение этих задач в несколько тысяч раз, что реально обеспечивает интеллектуальную обработку больших данных, большой информации и больших знаний;

- обеспечивает преобразование исходных эмпирических данных в информацию, а ее в знания и решение с использованием этих знаний задач классификации, поддержки принятия решений и исследования предметной области путем исследования ее системно-когнитивной модели, генерируя при этом очень большое количество табличных и графических выходных форм (развития когнитивная графика), у многих из которых нет никаких аналогов в других системах (примеры форм можно посмотреть в работе: http://lc.kubagro.ru/aidos/aidos18_LLS/aidos18_LLS.pdf);

- хорошо имитирует человеческий стиль мышления: дает результаты анализа, понятные экспертам на основе их опыта, интуиции и профессиональной компетенции.

Всем этим и обусловлен выбор АСК-анализа и его программного инструментария - интеллектуальной системы «Эйдос» в качестве метода и инструмента решения поставленной проблемы и достижения цели работы (рисунок 1). 


\section{Последовательность обработки данных, информации и знаний в системе «Эйдос-X++»}

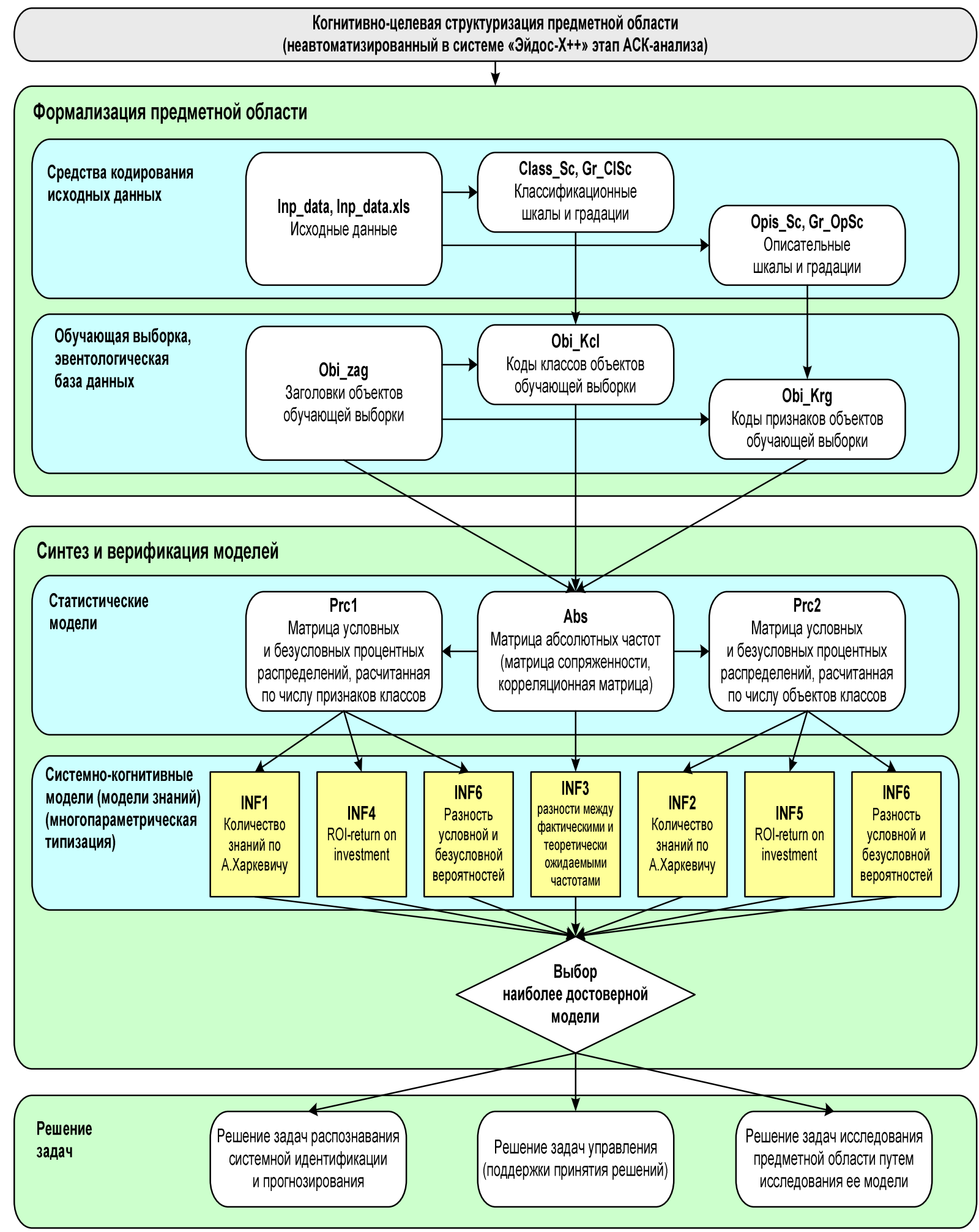

Рисунок 1. Последовательность решения задач

в АСК-анализе и системе «Эйдос»

Рассмотрим решение поставленных задач в подробном численном примере. 


\section{Задача 1: когнитивная структуризация предметной области}

На этапе когнитивно-целевой структуризации предметной области мы неформализуемым путем решаем на качественном уровне, что будем рассматривать в качестве факторов, действующих на моделируемый объект (причин), а что в качестве результатов действия этих факторов (последствий).

При этом необходимо отметить, что системно-когнитивные модели (СК-модели) отражают лишь сам факт наличия зависимостей между значениями факторов и результатами их действия. Но они не отражают причин и механизмов такого влияния.

Это значит:

- o-nервыx, что содержательная интерпретация СК-моделей - это компетенция специалистов-экспертов хорошо разбирающихся в данной предметной области. Иногда встречается ситуация, когда и то, что на первый взгляд является причинами, и то, что казалось бы является их последствиями, на самом деле является последствиями неких глубинных причин, которых мы не видим и никоим образом непосредственно не отражаем в модели [17];

- во-вторых, даже если содержательной интерпретации не разработано, то в принципе это не исключает возможности пользоваться ими на практике для достижения заданных результатов и поставленных целей, т.е. для управления [17].

В данной работе в качестве классификационных шкал выберем содержание жира и белка в коровьем молоке (таблица 1), а в качестве факторов, влияющих на эти результаты - различные параметры тензиограмм динамического поверхностного натяжения на границе раздела молоко/воздух (таблица 2):

Таблица 1 - Классификационные

Таблица 2 - Описательные шкалы

\begin{tabular}{|c|l|}
\multicolumn{2}{c}{ шкалы } \\
\hline Код & Наименование \\
\hline 1 & ЖИР, \% \\
\hline 2 & БЕЛОК, \% \\
\hline
\end{tabular}

\begin{tabular}{|c|c|}
\hline Код & Наименование \\
\hline 1 & P1 \\
\hline 2 & P2 \\
\hline 3 & P3 \\
\hline 4 & P4 \\
\hline 5 & P5 \\
\hline 6 & P6 \\
\hline
\end{tabular}

Расшифровка наименований параметров тензиограмм динамического поверхностного натяжения на границе раздела молоко/воздух ничего не скажет специалистам в области ветеринарии и зоотехнии, на которых ориентирована данная работа, и здесь не приводится. Интересующихся этим вопросом более глубоко авторы отсылают к работам [1-7]. 


\section{Задача 2: подготовка исходных данных и формализация предметной области}

Исходные данные для данной статьи (таблица 3) взяты без изменения из работы [1]. Исходные данные приведены полностью. Единственное что сделано: введены условные обозначения наименований параметров тензиограмм динамического поверхностного натяжения на границе раздела молоко/воздух.

Таблица 3 - Исходные экспериментальные данные для ввода в систему «Эйдос» 1

\begin{tabular}{|c|c|c|c|c|c|c|c|c|}
\hline Проба & P1 & P2 & P3 & P4 & P5 & P6 & Жир, \% & Белок, \% \\
\hline 1 & 57,23 & 57,47 & 51,67 & 45,92 & 5,49 & 5,77 & 2,29 & 2,81 \\
\hline 2 & 58,29 & 58,60 & 51,93 & 45,24 & 6,70 & 7,02 & 2,43 & 2,75 \\
\hline 3 & 55,92 & 56,30 & 50,02 & 44,21 & 6,41 & 6,19 & 2,48 & 2,99 \\
\hline 4 & 57,42 & 56,63 & 50,34 & 46,34 & 8,30 & 4,11 & 2,05 & 3,21 \\
\hline 5 & 56,45 & 57,71 & 50,52 & 40,62 & 5,86 & 10,13 & 3,85 & 4,02 \\
\hline 6 & 57,54 & 60,14 & 50,98 & 43,46 & 6,71 & 7,87 & 3,74 & 3,28 \\
\hline 7 & 58,14 & 58,56 & 51,81 & 45,34 & 6,59 & 6,76 & 3,69 & 3,09 \\
\hline 8 & 56,86 & 60,42 & 50,15 & 44,51 & 7,35 & 5,74 & 3,66 & 3,72 \\
\hline 9 & 69,33 & 70,16 & 59,40 & 50,54 & 10,77 & 9,10 & 2,79 & 2,99 \\
\hline 10 & 58,58 & 58,33 & 51,80 & 44,93 & 7,00 & 7,07 & 3,17 & 3,04 \\
\hline 11 & 59,19 & 59,05 & 52,48 & 44,40 & 7,30 & 8,66 & 3,49 & 3,35 \\
\hline 12 & 61,67 & 63,47 & 54,43 & 45,77 & 8,05 & 9,02 & 3,25 & 3,05 \\
\hline 13 & 59,08 & 57,70 & 52,45 & 45,42 & 7,17 & 7,61 & 3,47 & 3,70 \\
\hline 14 & 58,96 & 58,65 & 53,00 & 42,03 & 6,55 & 13,38 & 3,49 & 3,28 \\
\hline 15 & 57,95 & 62,97 & 51,13 & 45,14 & 8,02 & 5,62 & 3,27 & 3,67 \\
\hline 16 & 63,57 & 62,82 & 57,54 & 49,76 & 6,07 & 7,80 & 3,49 & 3,44 \\
\hline 17 & 61,35 & 64,94 & 53,45 & 46,92 & 8,84 & 6,73 & 3,00 & 3,30 \\
\hline 18 & 56,08 & 59,73 & 50,15 & 44,65 & 6,11 & 5,66 & 3,44 & 3,36 \\
\hline 19 & 59,80 & 59,65 & 52,77 & 47,16 & 7,77 & 5,55 & 3,66 & 3,33 \\
\hline 20 & 59,34 & 63,67 & 51,75 & 45,51 & 8,52 & 6,63 & 3,81 & 2,92 \\
\hline 21 & 57,41 & 60,44 & 53,18 & 46,58 & 3,59 & 6,71 & 3,59 & 3,29 \\
\hline 22 & 57,90 & 57,03 & 51,69 & 43,10 & 6,39 & 9,00 & 3,15 & 3,44 \\
\hline 23 & 59,84 & 64,44 & 53,07 & 45,33 & 7,28 & 8,42 & 3,33 & 3,50 \\
\hline 24 & 59,18 & 58,86 & 52,61 & 46,95 & 6,46 & 5,75 & 3,90 & 3,41 \\
\hline 25 & 60,56 & 60,24 & 55,28 & 52,30 & 5,83 & 2,85 & 2,79 & 3,76 \\
\hline 26 & 57,63 & 57,22 & 51,93 & 45,36 & 5,65 & 6,24 & 3,48 & 3,20 \\
\hline 27 & 55,79 & 57,82 & 51,68 & 47,20 & 4,92 & 5,13 & 3,75 & 3,10 \\
\hline 28 & 71,80 & 69,88 & 64,07 & 57,11 & 8,10 & 7,13 & 4,20 & 3,39 \\
\hline 29 & 58,11 & 58,10 & 53,30 & 46,44 & 4,43 & 7,06 & 4,35 & 3,13 \\
\hline 30 & 58,99 & 58,24 & 52,85 & 47,86 & 6,34 & 4,86 & 4,83 & 3,51 \\
\hline 31 & 59,71 & 59,05 & 54,10 & 46,23 & 5,56 & 8,17 & 4,04 & 3,32 \\
\hline 32 & 57,50 & 57,09 & 50,13 & 43,87 & 8,19 & 6,54 & 4,10 & 3,42 \\
\hline 33 & 57,46 & 58,62 & 53,55 & 46,70 & 3,72 & 7,17 & 4,32 & 2,79 \\
\hline 34 & 58,55 & 58,45 & 51,03 & 44,78 & 8,22 & 6,64 & 4,79 & 3,96 \\
\hline 35 & 57,11 & 57,44 & 50,38 & 42,23 & 7,38 & 8,94 & 4,55 & 3,50 \\
\hline 36 & 58,95 & 58,62 & 52,04 & 45,91 & 8,88 & 6,45 & 4,64 & 3,96 \\
\hline 37 & 69,94 & 71,17 & 61,57 & 58,42 & 10,58 & 3,10 & 4,03 & 3,58 \\
\hline 38 & 61,35 & 61,36 & 54,49 & 47,44 & 8,15 & 7,32 & 4,13 & 3,40 \\
\hline 39 & 56,49 & 58,44 & 49,59 & 43,51 & 8,00 & 6,35 & 5,04 & 3,22 \\
\hline 40 & 55,37 & 60,08 & 48,74 & 46,21 & 6,93 & 1,83 & 7,01 & 3,90 \\
\hline 41 & 75,39 & 75,42 & 67,72 & 54,99 & 7,58 & 13,90 & 3,62 & 3,82 \\
\hline 42 & 60,63 & 59,51 & 53,38 & 48,33 & 8,70 & 5,15 & 3,69 & 3,64 \\
\hline 43 & 58,24 & 59,86 & 53,20 & 47,72 & 5,42 & 6,02 & 3,75 & 3,22 \\
\hline 44 & 55,06 & 55,61 & 51,40 & 44,76 & 3,79 & 7,05 & 2,57 & 3,12 \\
\hline 45 & 63,16 & 65,02 & 55,83 & 49,85 & 8,63 & 6,34 & 3,93 & 3,57 \\
\hline 46 & 55,43 & 54,50 & 48,58 & 42,00 & 8,09 & 6,62 & 3,50 & 3,25 \\
\hline 47 & 59,85 & 59,45 & 53,02 & 48,38 & 8,56 & 4,55 & 3,78 & 3,32 \\
\hline 48 & 60,05 & 59,65 & 54,30 & 45,64 & 5,39 & 9,18 & 3,40 & 3,50 \\
\hline
\end{tabular}

1 Таблицу исходных данных 1 можно скачать с FTP-сервера системы «Эйдос» по ссылке: http://aidos.byethost5.com/Source_data_applications/Applications-000154/Inp_data.xls. Данная таблица взята из работы [1]. 


\begin{tabular}{|c|c|c|c|c|c|c|c|c|}
\hline 49 & 66,48 & 66,97 & 60,86 & 53,27 & 4,81 & 7,42 & 3,04 & 3,24 \\
\hline 50 & 55,76 & 54,84 & 49,46 & 43,92 & 7,21 & 5,92 & 5,34 & 3,91 \\
\hline 51 & 60,95 & 64,20 & 50,48 & 44,88 & 12,67 & 5,53 & 3,91 & 3,21 \\
\hline 52 & 71,68 & 70,83 & 67,04 & 53,56 & 2,31 & 13,93 & 2,61 & 3,09 \\
\hline 53 & 56,16 & 57,22 & 49,03 & 43,08 & 8,36 & 6,37 & 3,58 & 3,34 \\
\hline 54 & 63,28 & 68,58 & 51,16 & 45,15 & 16,40 & 6,20 & 3,96 & 3,05 \\
\hline 55 & 51,16 & 54,52 & 48,76 & 44,13 & 5,89 & 4,84 & 3,99 & 2,93 \\
\hline 56 & 61,79 & 61,53 & 55,83 & 49,31 & 6,12 & 6,99 & 4,42 & 4,25 \\
\hline 57 & 58,87 & 59,19 & 53,38 & 46,85 & 6,13 & 6,94 & 4,25 & 3,49 \\
\hline 58 & 62,85 & 62,78 & 56,24 & 50,90 & 6,99 & 5,49 & 4,60 & 3,45 \\
\hline 59 & 56,16 & 57,48 & 51,13 & 46,38 & 5,42 & 4,80 & 4,96 & 4,48 \\
\hline 60 & 55,38 & 55,42 & 48,18 & 41,92 & 9,26 & 6,73 & 4,69 & 3,69 \\
\hline 61 & 58,14 & 60,43 & 54,33 & 48,99 & 3,14 & 5,44 & 4,96 & 4,53 \\
\hline 62 & 64,50 & 64,67 & 57,80 & 51,94 & 6,84 & 5,81 & 4,73 & 3,19 \\
\hline 63 & 55,12 & 53,74 & 49,98 & 45,35 & 6,22 & 4,99 & 4,56 & 3,64 \\
\hline 64 & 61,46 & 61,01 & 54,53 & 47,86 & 7,38 & 6,96 & 4,05 & 3,99 \\
\hline 65 & 57,34 & 56,40 & 50,83 & 44,86 & 7,43 & 6,66 & 4,02 & 3,37 \\
\hline 66 & 56,93 & 56,93 & 50,25 & 44,27 & 7,16 & 6,08 & 5,17 & 3,72 \\
\hline 67 & 58,14 & 59,27 & 52,49 & 47,94 & 6,97 & 4,93 & 4,54 & 3,62 \\
\hline 68 & 57,45 & 56,60 & 51,98 & 45,60 & 5,19 & 6,57 & 4,42 & 3,17 \\
\hline 69 & 63,02 & 62,58 & 55,80 & 48,70 & 7,44 & 7,35 & 4,20 & 3,15 \\
\hline 70 & 73,23 & 72,62 & 65,68 & 50,95 & 7,34 & 17,35 & 4,05 & 3,26 \\
\hline 71 & 54,47 & 54,41 & 49,63 & 45,74 & 5,20 & 3,91 & 4,52 & 3,10 \\
\hline 72 & 56,50 & 57,18 & 50,90 & 45,24 & 5,98 & 6,03 & 4,38 & 3,16 \\
\hline 73 & 55,43 & 55,98 & 49,19 & 45,32 & 7,34 & 3,95 & 4,40 & 3,27 \\
\hline 74 & 53,94 & 52,20 & 47,00 & 40,38 & 8,56 & 6,80 & 4,28 & 3,22 \\
\hline 75 & 56,17 & 54,65 & 49,80 & 45,20 & 7,39 & 5,12 & 6,47 & 3,63 \\
\hline 76 & 60,09 & 60,03 & 50,32 & 44,77 & 12,35 & 5,53 & 2,14 & 3,64 \\
\hline 77 & 57,85 & 57,67 & 48,51 & 41,24 & 10,58 & 7,64 & 2,13 & 3,27 \\
\hline 78 & 62,44 & 61,94 & 55,56 & 47,99 & 8,32 & 8,25 & 3,43 & 3,05 \\
\hline 79 & 74,38 & 74,79 & 71,53 & 63,42 & 3,97 & 9,15 & 2,92 & 2,96 \\
\hline 80 & 58,20 & 58,92 & 51,72 & 46,32 & 7,27 & 5,65 & 3,50 & 3,17 \\
\hline 81 & 56,85 & 57,04 & 49,32 & 44,19 & 9,35 & 5,28 & 3,95 & 3,47 \\
\hline 82 & 60,65 & 62,40 & 56,45 & 52,88 & 5,01 & 3,97 & 3,26 & 3,20 \\
\hline 83 & 62,97 & 64,70 & 65,98 & 62,62 & 3,00 & 3,48 & 3,99 & 3,50 \\
\hline 84 & 58,66 & 60,19 & 50,30 & 45,50 & 10,25 & 4,57 & 3,76 & 3,39 \\
\hline 85 & 59,87 & 58,94 & 50,27 & 46,22 & 13,28 & 4,77 & 3,59 & 3,68 \\
\hline 86 & 57,37 & 59,20 & 50,16 & 44,01 & 8,10 & 6,38 & 3,70 & 3,06 \\
\hline 87 & 56,87 & 57,20 & 48,25 & 44,56 & 9,74 & 3,10 & 3,95 & 3,25 \\
\hline 88 & 58,77 & 58,47 & 54,05 & 42,72 & 5,07 & 13,20 & 3,90 & 3,20 \\
\hline 89 & 53,21 & 52,52 & 47,57 & 42,49 & 5,76 & 5,62 & 3,90 & 3,09 \\
\hline 90 & 56,72 & 55,95 & 49,81 & 43,03 & 7,18 & 7,11 & 3,98 & 3,31 \\
\hline 91 & 56,84 & 56,77 & 51,80 & 48,67 & 4,39 & 3,03 & 3,69 & 3,44 \\
\hline 92 & 54,04 & 54,02 & 49,93 & 46,00 & 3,97 & 4,15 & 4,87 & 3,44 \\
\hline 93 & 57,26 & 56,87 & 51,35 & 46,32 & 6,86 & 5,08 & 4,46 & 3,50 \\
\hline 94 & 58,38 & 55,50 & 50,86 & 45,10 & 5,62 & 5,65 & 5,31 & 3,32 \\
\hline 95 & 54,27 & 55,03 & 48,54 & 45,05 & 6,66 & 3,52 & 4,03 & 3,52 \\
\hline 96 & 57,03 & 56,82 & 53,26 & 49,70 & 4,18 & 3,27 & 4,14 & 3,67 \\
\hline 97 & 55,40 & 56,45 & 47,86 & 42,46 & 7,84 & 5,16 & 4,09 & 3,84 \\
\hline 98 & 54,89 & 54,89 & 48,77 & 45,25 & 6,30 & 2,92 & 4,45 & 4,11 \\
\hline 99 & 56,32 & 56,23 & 51,15 & 44,38 & 5,21 & 7,00 & 4,46 & 3,65 \\
\hline 100 & 57,48 & 57,49 & 51,03 & 46,81 & 7,31 & 4,33 & 4,30 & 3,39 \\
\hline 101 & 50,78 & 55,35 & 62,00 & 60,94 & 11,63 & 1,73 & 5,24 & 3,68 \\
\hline 102 & 57,82 & 60,06 & 50,45 & 44,90 & 9,13 & 5,56 & 4,51 & 3,56 \\
\hline 103 & 54,78 & 54,68 & 45,93 & 42,35 & 9,98 & 3,31 & 5,55 & 3,43 \\
\hline 104 & 55,97 & 54,53 & 48,41 & 43,84 & 8,10 & 4,73 & 5,67 & 3,43 \\
\hline 105 & 52,86 & 65,22 & 68,28 & 67,34 & 5,44 & 1,16 & 4,27 & 3,18 \\
\hline 106 & 55,41 & 55,47 & 48,17 & 47,94 & 8,62 & 3,96 & 4,74 & 3,03 \\
\hline 107 & 60,87 & 60,49 & 55,27 & 51,04 & 6,49 & 4,36 & 6,10 & 4,39 \\
\hline 108 & 70,72 & 66,98 & 62,66 & 59,70 & 11,25 & 3,15 & 6,38 & 3,67 \\
\hline 109 & 54,21 & 54,02 & 46,65 & 45,39 & 8,75 & 0,97 & 6,15 & 4,00 \\
\hline 110 & 54,11 & 54,04 & 49,25 & 44,19 & 5,23 & 5,36 & 6,09 & 3,52 \\
\hline 111 & 54,90 & 54,57 & 47,32 & 43,72 & 9,17 & 3,70 & 6,29 & 3,33 \\
\hline 112 & 55,96 & 56,59 & 48,33 & 48,97 & 9,25 & 1,85 & 6,10 & 3,48 \\
\hline
\end{tabular}

Затем с параметрами, показанными на рисунке 2 , запустим режим 2.3.2.2 системы «Эйдос», представляющий собой автоматизированный программный интерфейс (API) с внешними данными табличного типа. На рисунке 2 приведены реально использованные параметры. 

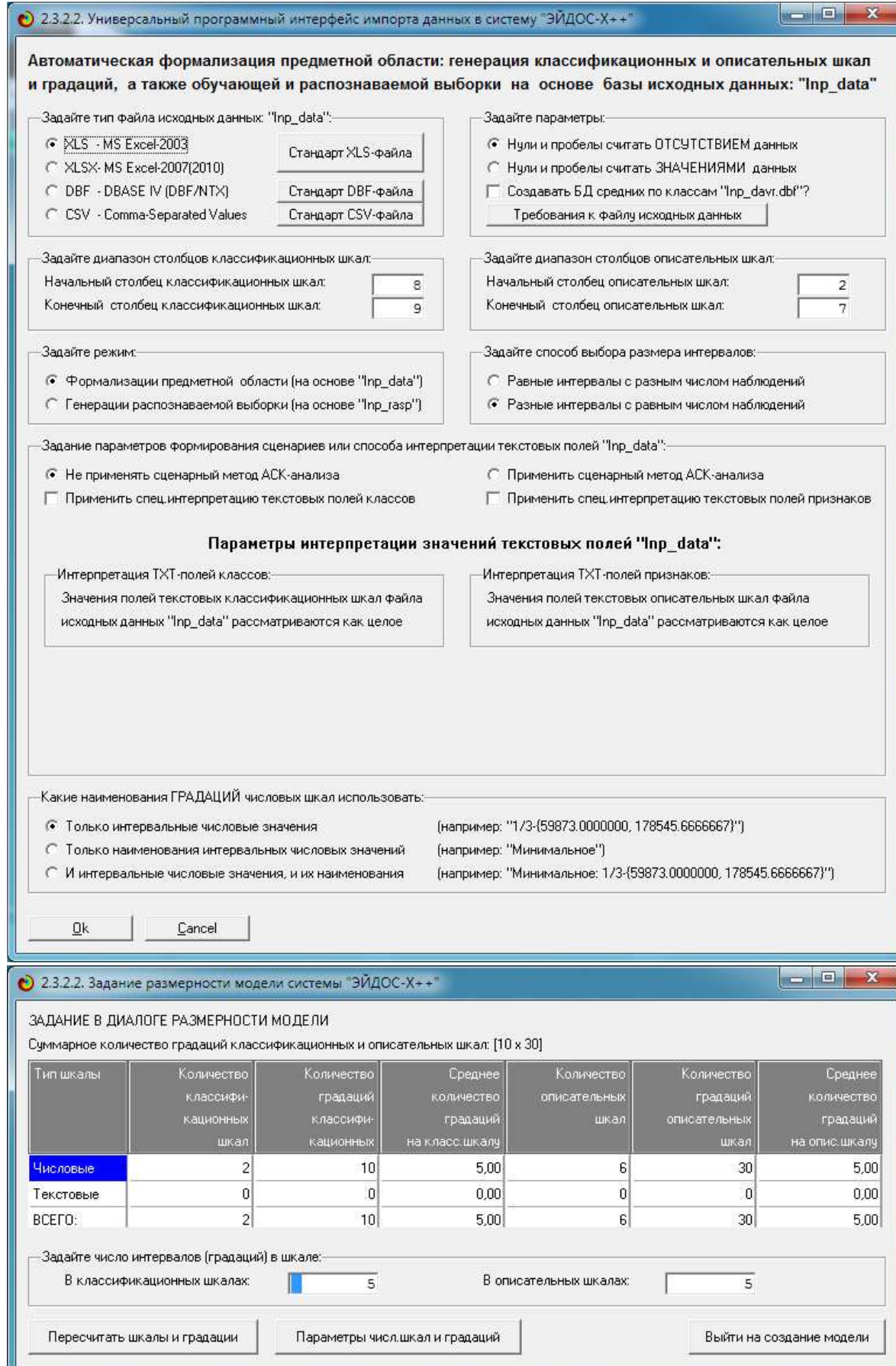

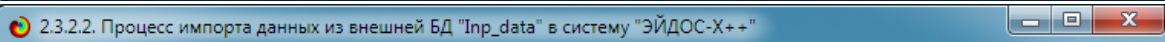

Стадии исполнения процесса
1/3: Формирование классификационных и описательных шкал и градаций на основе БД "Inp_data"-Готово
2/3: Генерация обучающей выборки и базы событий "EventsKO" на основе внешней БД "Inp_data"- Готово

3/3: Переиндексация всех баз данныхнового приложения-Готово

ПРОЦЕСС ФОРМАЛИЗАЦИИ ПРЕДМЕТНОЙ ОБЛАСТИ ЗАВЕРШЕН УСПЕШНО !!!

Прогноз времени исполнения

$\begin{array}{ll}\text { Начало: 14:38:54 } & \text { Окончание: 14:38:57 }\end{array}$

\begin{tabular}{lll|l}
$\underline{0} \mathrm{Q} k$ \\
\hline
\end{tabular}

$\begin{array}{ll}\text { Прошло: 0:00:02 } & \text { Осталось: 0:00:00 }\end{array}$

Рисунок 2. Экранные форма программного интерфейса (API) 2.3.2.2 системы «Эйдос» с внешними данными табличного типа 
Обратим внимание на то, что заданы адаптивные интервалы, учитывающее неравномерность распределения данных по диапазону значений, что важно при относительно небольшом числе наблюдений. Если бы интервалы были заданы равными по величине, то в них бы учитывалось сильно отличающееся число наблюдений, а в некоторых интервалах их бы могло не оказаться вовсе. И в классификационных, и в описательных шкалах задано 5 числовых интервальных значения.

На рисунке 3 приведен Help данного режима, в котором объясняется принцип организации таблицы исходных данных для данного режима. Здесь же обратим внимание на то, что в таблице 3 как значения параметров ДПН коровьего молока, так и содержание в нем жира и белка, могут быть представлены как числовыми, так и текстовыми значениями.

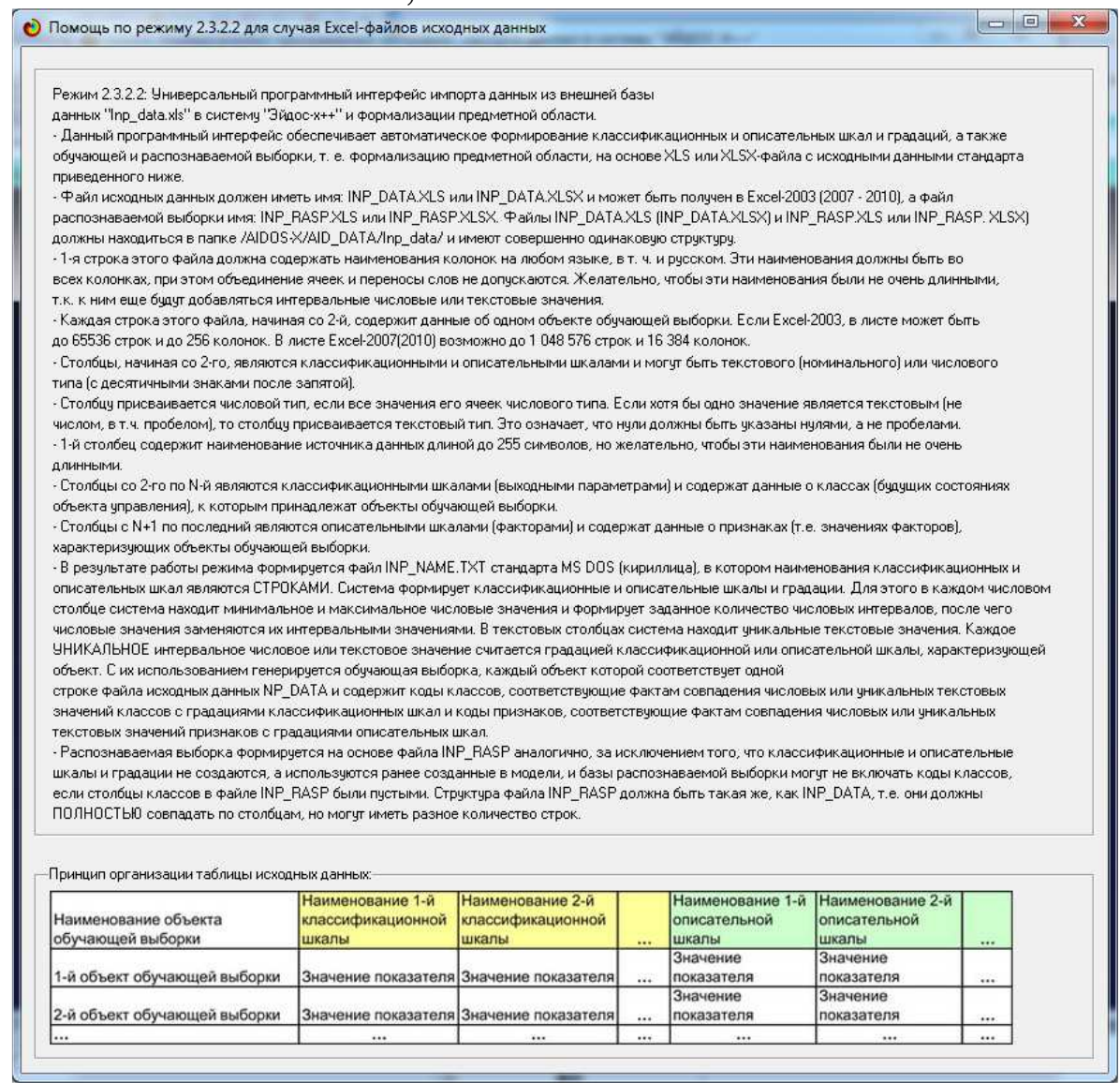

Рисунок 3. Экранные форма HELP программного интерфейса (API) 2.3.2.2

В результате работы режима сформировано 2 классификационных шкалы с суммарным количеством градаций (классов) 10 (таблица 4) и 6 описательных шкал с суммарным числом градаций 30. С использованием классификационных и описательных шкал и градаций (таблицы 4 и 5) исходные данные (таблица 3) были закодированы и в результате получена обучающая выборка (таблица 6):

\footnotetext{
${ }^{2}$ Все рисунки в статье приведены с достаточно высоким разрешением и при увеличении масштаба просмотра вполне читабельны
} 
Таблица 4 - Классификационные шкалы и градации (содержание жира и белка в коровьем молоке)

\begin{tabular}{|c|l|}
\hline Код & Наименование \\
\hline 1 & ЖИР, \%-1/5-\{2.0500000, 3.4400000\} \\
\hline 2 & ЖИР, \%-2/5-\{3.4400000, 3.7800000\} \\
\hline 3 & ЖИР, \%-3/5-\{3.7800000, 4.1300000\} \\
\hline 4 & ЖИР, \%-4/5-\{4.1300000, 4.6400000\} \\
\hline 5 & ЖИР, \%-5/5-\{4.6400000, 7.0100000\} \\
\hline 6 & БЕЛОК, \%-1/5-\{2.7500000, 3.1500000\} \\
\hline 7 & БЕЛОК, \%-2/5-\{3.1500000, 3.2900000\} \\
\hline 8 & БЕЛОК, \%-3/5-\{3.2900000, 3.4400000\} \\
\hline 9 & БЕЛОК, \%-4/5-\{3.4400000, 3.6700000\} \\
\hline 10 & БЕЛОК, \%-5/5-\{3.6700000, 4.5300000 \\
\hline
\end{tabular}

Таблица 5 - Описательные шкалы и градации (параметры тензиограмм динамического поверхностного натяжения на границе раздела молоко/воздух)

\begin{tabular}{|c|c|}
\hline Код & Наименование \\
\hline 1 & $\mathrm{P} 1-1 / 5-\{50.7800000,55.7600000\}$ \\
\hline 2 & $\mathrm{P} 1-2 / 5-\{55.7600000,57.2600000\}$ \\
\hline 3 & $\mathrm{P} 1-3 / 5-\{57.2600000,58.3800000\}$ \\
\hline 4 & $\mathrm{P} 1-4 / 5-\{58.3800000,60.8700000\}$ \\
\hline 5 & $\mathrm{P} 1-5 / 5-\{60.8700000,75.3900000\}$ \\
\hline 6 & P2-1/5-\{52.2000000, 55.95 \\
\hline 7 & P2-2/5-\{55.9 \\
\hline 8 & P2-3/5- $\{57.4800000,59.1900000\}$ \\
\hline 9 & P2-4/5- $\{59.1900000,62.4000000\}$ \\
\hline 10 & P2-5/5-\{62.4000000, 75.4200000\} \\
\hline 11 & P3-1/5- $\{45.9300000,49.4600000\}$ \\
\hline 12 & P3-2/5-\{49.4600000, 50.8 \\
\hline 13 & P3-3/5- $\{5$ \\
\hline 14 & P3-4/5 \\
\hline 15 & P3-5/5-\{5 \\
\hline 16 & P4-1/5-\{40.3800000, 44.1300000\} \\
\hline 17 & P4-2/5-\{44.1300000, 45.2400000\} \\
\hline 18 & P4-3/5-\{45.2400000, 46.3200000\} \\
\hline 19 & P4-4/5- $\{46.3200000,48.7000000\}$ \\
\hline 20 & $\mathrm{P} 4-5 / 5-\{48.7000$ \\
\hline 21 & P5-1/5- \\
\hline 22 & P5-2/5-\{5.4200000, 6.5500 \\
\hline 23 & P5-3/5-\{6.5500000, 7.3800000\} \\
\hline 24 & P5-4/5-\{7.3800000, 8.5600000\} \\
\hline 25 & P5-5/5-\{8.5600000, 16.4000000\} \\
\hline 26 & $P 6-1 / 5-\{0.9700000,4.1500000\}$ \\
\hline 27 & $P 6-2 / 5-\{4.1500000,5.5300000\}$ \\
\hline 28 & P6-3/5-\{5.5300000, 6.3800000\} \\
\hline 29 & $P 6-4 / 5-\{6.3800000,7.1700000\}$ \\
\hline 30 & $P 6-5 / 5-\{7.1700000,17.3500000\}$ \\
\hline
\end{tabular}


Таблица 6 - Обучающая выборка

\begin{tabular}{|c|c|c|c|c|c|c|c|c|c|c|c|c|c|c|c|c|c|}
\hline Проба & $\mathrm{P} 1$ & P2 & P3 & P4 & P5 & P6 & P7 & P8 & Проба & $\mathrm{P} 1$ & P2 & P3 & P4 & P5 & P6 & P7 & P8 \\
\hline 1 & 2 & 7 & 13 & 18 & 22 & 28 & 1 & 6 & 57 & 4 & 8 & 14 & 19 & 22 & 29 & 4 & 9 \\
\hline 2 & 3 & 8 & 13 & 17 & 23 & 29 & 1 & 6 & 58 & 5 & 10 & 15 & 20 & 23 & 27 & 4 & 9 \\
\hline 3 & 2 & 7 & 12 & 17 & 22 & 28 & 1 & 6 & 59 & 2 & 7 & 13 & 19 & 21 & 27 & 5 & 10 \\
\hline 4 & 3 & 7 & 12 & 19 & 24 & 26 & 1 & 7 & 60 & 1 & 6 & 11 & 16 & 25 & 29 & 5 & 10 \\
\hline 5 & 2 & 8 & 12 & 16 & 22 & 30 & 3 & 10 & 61 & 3 & 9 & 14 & 20 & 21 & 27 & 5 & 10 \\
\hline 6 & 3 & 9 & 13 & 16 & 23 & 30 & 2 & 7 & 62 & 5 & 10 & 15 & 20 & 23 & 28 & 5 & 7 \\
\hline 7 & 3 & 8 & 13 & 18 & 23 & 29 & 2 & 6 & 63 & 1 & 6 & 12 & 18 & 22 & 27 & 4 & 9 \\
\hline 8 & 2 & 9 & 12 & 17 & 23 & 28 & 2 & 10 & 64 & 5 & 9 & 15 & 19 & 23 & 29 & 3 & 10 \\
\hline 9 & 5 & 10 & 15 & 20 & 25 & 30 & 1 & 6 & 65 & 3 & 7 & 12 & 17 & 24 & 29 & 3 & 8 \\
\hline 10 & 4 & 8 & 13 & 17 & 23 & 29 & 1 & 6 & 66 & 2 & 7 & 12 & 17 & 23 & 28 & 5 & 10 \\
\hline 11 & 4 & 8 & 14 & 17 & 23 & 30 & 2 & 8 & 67 & 3 & 9 & 14 & 19 & 23 & 27 & 4 & 9 \\
\hline 12 & 5 & 10 & 14 & 18 & 24 & 30 & 1 & 6 & 68 & 3 & 7 & 13 & 18 & 21 & 29 & 4 & 7 \\
\hline 13 & 4 & 8 & 14 & 18 & 23 & 30 & 2 & 10 & 69 & 5 & 10 & 15 & 19 & 24 & 30 & 4 & 6 \\
\hline 14 & 4 & 8 & 14 & 16 & 22 & 30 & 2 & 7 & 70 & 5 & 10 & 15 & 20 & 23 & 30 & 3 & 7 \\
\hline 15 & 3 & 10 & 13 & 17 & 24 & 28 & 1 & 9 & 71 & 1 & 6 & 12 & 18 & 21 & 26 & 4 & 6 \\
\hline 16 & 5 & 10 & 15 & 20 & 22 & 30 & 2 & 8 & 72 & 2 & 7 & 13 & 17 & 22 & 28 & 4 & 7 \\
\hline 17 & 5 & 10 & 14 & 19 & 25 & 29 & 1 & 8 & 73 & 1 & 7 & 11 & 18 & 23 & 26 & 4 & 7 \\
\hline 18 & 2 & 9 & 12 & 17 & 22 & 28 & 1 & 8 & 74 & 1 & 6 & 11 & 16 & 24 & 29 & 4 & 7 \\
\hline 19 & 4 & 9 & 14 & 19 & 24 & 28 & 2 & 8 & 75 & 2 & 6 & 12 & 17 & 24 & 27 & 5 & 9 \\
\hline 20 & 4 & 10 & 13 & 18 & 24 & 29 & 3 & 6 & 76 & 4 & 9 & 12 & 17 & 25 & 27 & 1 & 9 \\
\hline 21 & 3 & 9 & 14 & 19 & 21 & 29 & 2 & 7 & 77 & 3 & 8 & 11 & 16 & 25 & 30 & 1 & 7 \\
\hline 22 & 3 & 7 & 13 & 16 & 22 & 30 & 1 & 8 & 78 & 5 & 9 & 15 & 19 & 24 & 30 & 1 & 6 \\
\hline 23 & 4 & 10 & 14 & 18 & 23 & 30 & 1 & 9 & 79 & 5 & 10 & 15 & 20 & 21 & 30 & 1 & 6 \\
\hline 24 & 4 & 8 & 14 & 19 & 22 & 28 & 3 & 8 & 80 & 3 & 8 & 13 & 18 & 23 & 28 & 2 & 7 \\
\hline 25 & 4 & 9 & 15 & 20 & 22 & 26 & 1 & 10 & 81 & 2 & 7 & 11 & 17 & 25 & 27 & 3 & 9 \\
\hline 26 & 3 & 7 & 13 & 18 & 22 & 28 & 2 & 7 & 82 & 4 & 9 & 15 & 20 & 21 & 26 & 1 & 7 \\
\hline 27 & 2 & 8 & 13 & 19 & 21 & 27 & 2 & 6 & 83 & 5 & 10 & 15 & 20 & 21 & 26 & 3 & 9 \\
\hline 28 & 5 & 10 & 15 & 20 & 24 & 29 & 4 & 8 & 84 & 4 & 9 & 12 & 18 & 25 & 27 & 2 & 8 \\
\hline 29 & 3 & 8 & 14 & 19 & 21 & 29 & 4 & 6 & 85 & 4 & 8 & 12 & 18 & 25 & 27 & 2 & 10 \\
\hline 30 & 4 & 8 & 14 & 19 & 22 & 27 & 5 & 9 & 86 & 3 & 9 & 12 & 16 & 24 & 28 & 2 & 6 \\
\hline 31 & 4 & 8 & 14 & 18 & 22 & 30 & 3 & 8 & 87 & 2 & 7 & 11 & 17 & 25 & 26 & 3 & 7 \\
\hline 32 & 3 & 7 & 12 & 16 & 24 & 29 & 3 & 8 & 88 & 4 & 8 & 14 & 16 & 21 & 30 & 3 & 7 \\
\hline 33 & 3 & 8 & 14 & 19 & 21 & 29 & 4 & 6 & 89 & 1 & 6 & 11 & 16 & 22 & 28 & 3 & 6 \\
\hline 34 & 4 & 8 & 13 & 17 & 24 & 29 & 5 & 10 & 90 & 2 & 6 & 12 & 16 & 23 & 29 & 3 & 8 \\
\hline 35 & 2 & 7 & 12 & 16 & 23 & 30 & 4 & 9 & 91 & 2 & 7 & 13 & 19 & 21 & 26 & 2 & 8 \\
\hline 36 & 4 & 8 & 13 & 18 & 25 & 29 & 4 & 10 & 92 & 1 & 6 & 12 & 18 & 21 & 26 & 5 & 8 \\
\hline 37 & 5 & 10 & 15 & 20 & 25 & 26 & 3 & 9 & 93 & 2 & 7 & 13 & 18 & 23 & 27 & 4 & 9 \\
\hline 38 & 5 & 9 & 14 & 19 & 24 & 30 & 3 & 8 & 94 & 3 & 6 & 12 & 17 & 22 & 28 & 5 & 8 \\
\hline 39 & 2 & 8 & 12 & 16 & 24 & 28 & 5 & 7 & 95 & 1 & 6 & 11 & 17 & 23 & 26 & 3 & 9 \\
\hline 40 & 1 & 9 & 11 & 18 & 23 & 26 & 5 & 10 & 96 & 2 & 7 & 14 & 20 & 21 & 26 & 4 & 9 \\
\hline 41 & 5 & 10 & 15 & 20 & 24 & 30 & 2 & 10 & 97 & 1 & 7 & 11 & 16 & 24 & 27 & 3 & 10 \\
\hline 42 & 4 & 9 & 14 & 19 & 25 & 27 & 2 & 9 & 98 & 1 & 6 & 11 & 18 & 22 & 26 & 4 & 10 \\
\hline 43 & 3 & 9 & 14 & 19 & 21 & 28 & 2 & 7 & 99 & 2 & 7 & 13 & 17 & 21 & 29 & 4 & 9 \\
\hline 44 & 1 & 6 & 13 & 17 & 21 & 29 & 1 & 6 & 100 & 3 & 8 & 13 & 19 & 23 & 27 & 4 & 8 \\
\hline 45 & 5 & 10 & 15 & 20 & 25 & 28 & 3 & 9 & 101 & 1 & 6 & 15 & 20 & 25 & 26 & 5 & 10 \\
\hline 46 & 1 & 6 & 11 & 16 & 24 & 29 & 2 & 7 & 102 & 3 & 9 & 12 & 17 & 25 & 28 & 4 & 9 \\
\hline 47 & 4 & 9 & 14 & 19 & 24 & 27 & 2 & 8 & 103 & 1 & 6 & 11 & 16 & 25 & 26 & 5 & 8 \\
\hline 48 & 4 & 9 & 14 & 18 & 21 & 30 & 1 & 9 & 104 & 2 & 6 & 11 & 16 & 24 & 27 & 5 & 8 \\
\hline 49 & 5 & 10 & 15 & 20 & 21 & 30 & 1 & 7 & 105 & 1 & 10 & 15 & 20 & 22 & 26 & 4 & 7 \\
\hline 50 & 1 & 6 & 11 & 16 & 23 & 28 & 5 & 10 & 106 & 1 & 6 & 11 & 19 & 25 & 26 & 5 & 6 \\
\hline 51 & 5 & 10 & 12 & 17 & 25 & 27 & 3 & 7 & 107 & 4 & 9 & 15 & 20 & 22 & 27 & 5 & 10 \\
\hline 52 & 5 & 10 & 15 & 20 & 21 & 30 & 1 & 6 & 108 & 5 & 10 & 15 & 20 & 25 & 26 & 5 & 9 \\
\hline 53 & 2 & 7 & 11 & 16 & 24 & 28 & 2 & 8 & 109 & 1 & 6 & 11 & 18 & 25 & 26 & 5 & 10 \\
\hline 54 & 5 & 10 & 13 & 17 & 25 & 28 & 3 & 6 & 110 & 1 & 6 & 11 & 17 & 21 & 27 & 5 & 9 \\
\hline 55 & 1 & 6 & 11 & 16 & 22 & 27 & 3 & 6 & 111 & 1 & 6 & 11 & 16 & 25 & 26 & 5 & 8 \\
\hline 56 & 5 & 9 & 15 & 20 & 22 & 29 & 4 & 10 & 112 & 2 & 7 & 11 & 20 & 25 & 26 & 5 & 9 \\
\hline
\end{tabular}

Обучающая выборка (таблица 6), по сути, представляет собой нормализованные исходные данные, т.е. таблицу исходных данных (таблица 3), закодированную с помощью классификационных и описательных шкал и градаций (таблицы 4 и 5). Желтым фоном выделены классификационные шкалы. Таким образом, созданы все необходимые и достаточные условия для выполнения следующего этапа АСК-анализа: т.е. для синтеза и верификации моделей. 


\section{Задача 3: синтез и верификация статистических и системно-когнитивных моделей и выбор наиболее достоверной из них для решения задач}

Синтез и верификация статистических и системно-когнитивных моделей (СК-моделей) моделей осуществляется в режиме 3.5 системы «Эйдос» (рисунок 4). Сами эти модели описаны в ряде работ [7-16].

\begin{tabular}{|c|c|c|}
\hline \multicolumn{2}{|c|}{ () 3.5. Выбор моделей для синтеза и верификации } & 口回回 \\
\hline \multicolumn{2}{|l|}{ Задайте модели аля синтеза и верификации } & \multirow[t]{2}{*}{ Текущая модель } \\
\hline \multicolumn{2}{|l|}{ Статистические базы: } & \\
\hline \multicolumn{2}{|c|}{ V] [1. АВS - частный критерий. количество встреч сочетаний "кпасс-признак" у объектов обуч.выборки } & C $1 . \mathrm{ABS}$ \\
\hline \multicolumn{2}{|c|}{ 『 2. PRC1 - частный критерий: усл. вероятность і-го признака среди признаков объектов јго класса } & C 2. PRC1 \\
\hline \multicolumn{2}{|c|}{ 『v 3. PRC2 - частный критерий: условная вероятность і-го признака у объектов і-го класса } & C 3. PRC2 \\
\hline \multicolumn{3}{|c|}{ Системно-когнитивные модели (базы знаний): } \\
\hline \multicolumn{2}{|c|}{ V 4. INF1 - частный критерий: количество знаний по А.Харкевичу; вероятности из PRC1 } & \\
\hline \multicolumn{2}{|c|}{ 『 5. INF2 - частный критерий: количество знаний по А.Харкевичу; вероятности из PRC2 } & C 5. INF2 \\
\hline \multicolumn{2}{|c|}{ Г 6. INF3 - чәстный критерий: Хи-квадрат, разности между фактическими и ожидаемыми абс. частотами } & C 6. INF3 \\
\hline \multicolumn{2}{|c|}{ Г 7. INF4 - частный критерий: ROI (Return On Investment); вероятности из PRC1 } & C 7. INF4 \\
\hline \multicolumn{2}{|c|}{ 『 8. INF5 - частный критерий: ROI (Return On Investment); вероятности из PRC2 } & C 8. INF5 \\
\hline \multicolumn{2}{|c|}{ 『 9. INF6 - частный критерий: разн.усл.и безусл.вероятностей; вероятности из PRC1 } & C 9. INFG \\
\hline \multicolumn{2}{|c|}{ V 10.INF7 - частный критерий: разн.усл.и безусл.вероятностей; вероятности из PRC2 } & C 10.INF7 \\
\hline \multicolumn{3}{|c|}{ Параметры копирования обучающей выборки в распознаваемую: } \\
\hline 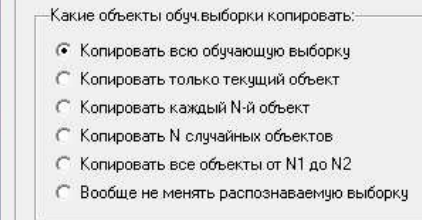 & Пояснение по алгоритму верификации & $\begin{array}{l}\text { Для каждой заданной } \\
\text { модели выполнить: } \\
\text { • Синтез и верификацию } \\
\text { С Только верификацию } \\
\text { С Только синтез }\end{array}$ \\
\hline $\begin{array}{l}\text { Удалять из обуч.выборки скопированные объекты- } \\
\text { С Не цдалять } \\
\ulcorner\text { Удалять }\end{array}$ & $\begin{array}{l}\text { Подробнее } \\
\text { Измеряется внутренняя достоверн. модели }\end{array}$ & $\begin{array}{l}\text { На каком процессоре } \\
\text { выполнять расчеты. }\end{array}$ \\
\hline Cancel & & \\
\hline
\end{tabular}

0) 3.5. Выбор моделей для синтеза и верификации

Стадии исполнения процесса

Шаг 1-й из 11: Копирование обччающей выборки в распознаваемчю - Готово

Шаг 2-й из 11: Синтез стат.модели "ABS" (расчет матрицы абсолютных частот) - Готово

Шаг 3-й из 11: Синтез стат.моделей "PRC1" и "PRC2" (усл.безусл.\% распр.) - Готово

Шаг 4-й из 11: Синтез системно-Когнитивныхмоделей: INF1-INF7 - Готово

НАЧАЛО ЦИКЛА ПО ЧАСТНЫМ И ИНТЕГРАЛЬНЫМ КРИТЕРИЯМ - ИСПОЛНЕНИЕ

Шаг 5-й из 11: Задание модели "INF7" в качестве текущей - Готово

Шаг 6-й из 11: Пакетное распознавание в модели "INF7" - Готово

Шаг 7-й из 11: Измерение достоверности модели: "Inf7" - Интегральный критерий: "Сумма знаний" - Готово

КОНЕЦЦИКЛА ПО ЧАСТНЫМ И ИНТЕГРАЛЬНЫМ КРИТЕРИЯМ -ГОТОВО

Шаг 8-й из 11: Объединение БДDostRsp\# в БД DostRasp - Готово

Шаг 9-й из 11: Печать сводной формы по резчльтатам верификации моделей - Готово

Шаг 10-й из 11: Создание формы: "Достоверность идент. классов в различныхмоделях" - Готово

Шаг 11-й из 11: "Присвоение заданной модели:Inf1статуса текцщей" - Готово

Прогноз времени исполнения

Начало: 15:08:44

Окончание: 15-09-05

$\begin{array}{ll}\text { Прошло: 0:00:20 } & \text { 0сталось: 0:00:00 }\end{array}$

$100 \%$

Рисунок 4. Экранные формы режима синтеза и верификации

статистических и системно-когнитивных моделей системы «Эйдос» 
Обратим внимание на то, что на рисунке 4 в правом нижнем углу окна задана опция: «Расчеты проводить на графическом процессор (GPU)».

Из рисунка 4 видно, что весь процесс синтеза и верификации моделей занял 20 секунд. Отметим, что при синтезе и верификации моделей использовался графический процессор (GPU) видеокарты. На центральном процессоре (CPU) выполнение этих операций занимает значительно большее время (на некоторых задачах это происходит в десятки, сотни и даже тысячи раз дольше). Таким образом, неграфические вычисления на графических процессорах видеокарты делает возможной обработку больших объемов исходных данных за разумное время. В процесс синтеза и верификации моделей осуществляется также расчет 10 выходных форм, на что уходит более $99 \%$ времени исполнения.

Фрагменты самих созданных статистических и системнокогнитивных моделей (СК-модели) приведены на рисунках 5, 6, 7:

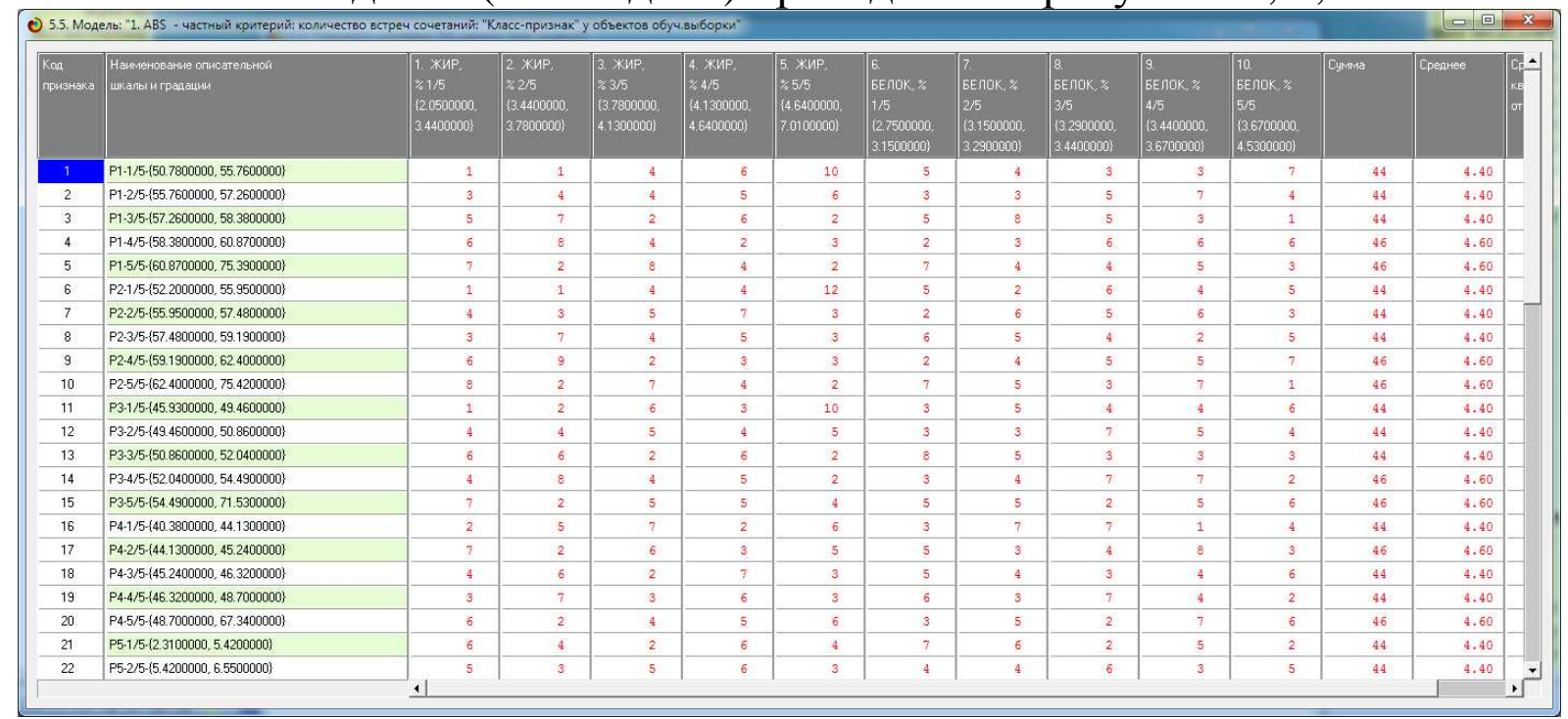

Рисунок 5. Матрица абсолютных частот (фрагмент)

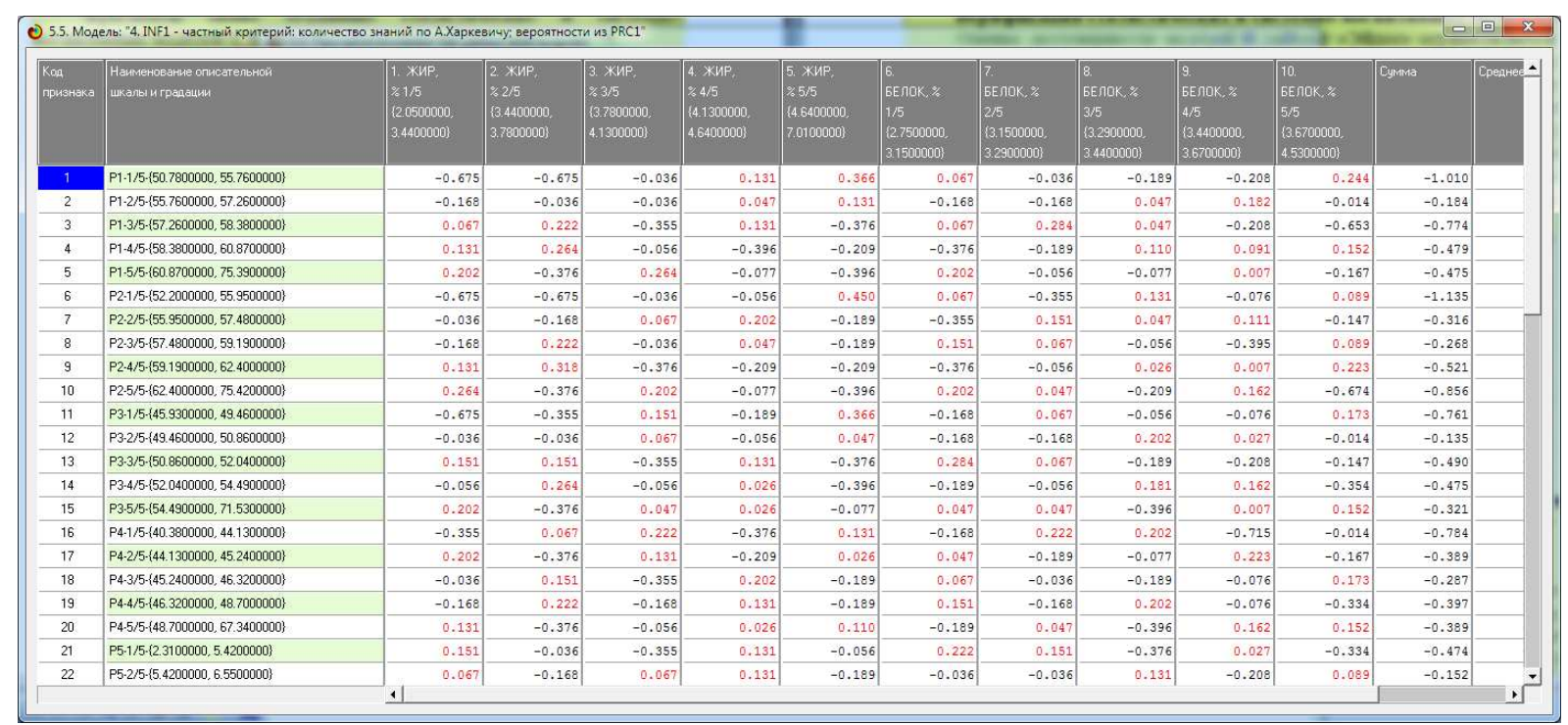

Рисунок 6. Матрица информативностей INF1 (фрагмент) 


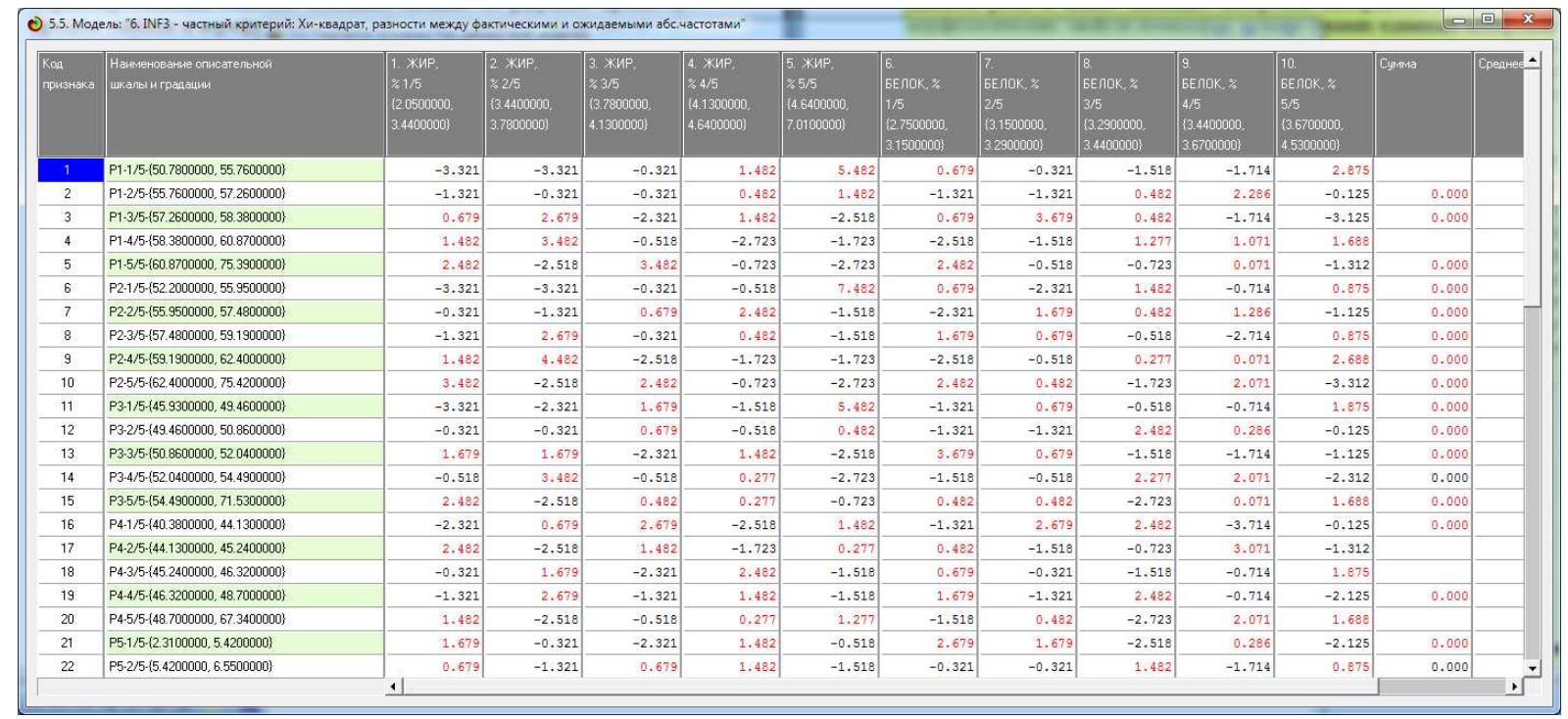

Рисунок 7. Модель INF3 (фрагмент)

Отметим, что в АСК-анализе и СК-моделях степень выраженности различных свойств объектов наблюдения рассматривается с единственной точки зрения: с точки зрения того, какое количество информации содержится в них о том, к каким обобщающим категориям (классам) будут принадлежать или не принадлежать эти объекты [9]. Поэтому не играет никакой роли в каких единицах измерения измеряются те или иные свойства объектов наблюдения, а также в каких единицах измеряются результаты влияния этих свойств, натуральных, в процентах или стоимостных [9]. Это и есть решение проблемы сопоставимости в АСКанализе и системе «Эйдос», отличающее их от других интеллектуальных технологий.

Верификация статистических и системно-когнитивных моделей

Оценка достоверности моделей в системе «Эйдос» осуществляется путем решения задачи классификации объектов обучающей выборки по обобщенным образам классов и подсчета количества истинных положительных и отрицательных, а также ложных положительных и отрицательных решений по F-мере Ван Ризбергена, а также по критериям L1- L2-мерам проф.Е.В.Луценко, которые предложены для того, чтобы смягчить или полностью преодолеть некоторые недостатки F-меры [10]. В режиме 3.4 системы «Эйдос» изучается достоверность каждой частной модели в соответствии с этими мерами достоверности (рисунок 8).

Из рисунка 8 мы видим, что в данном интеллектуальном приложении по F-критерию Ван Ризбергена наиболее достоверной является СК-модель INF1 (и INF2) с интегральным критерием «Сумма знаний» ( $\mathrm{F}=0,500$ при максимуме 1,000$)$, что является довольно слабым результатом, а по критерию L1 проф.Е.В.Луценко [10] наиболее достоверной также является CК-модель INF3 с интегральным критерием «Сумма знаний» (L1=0,604 при максимуме 1,000), что является средним результатом. 


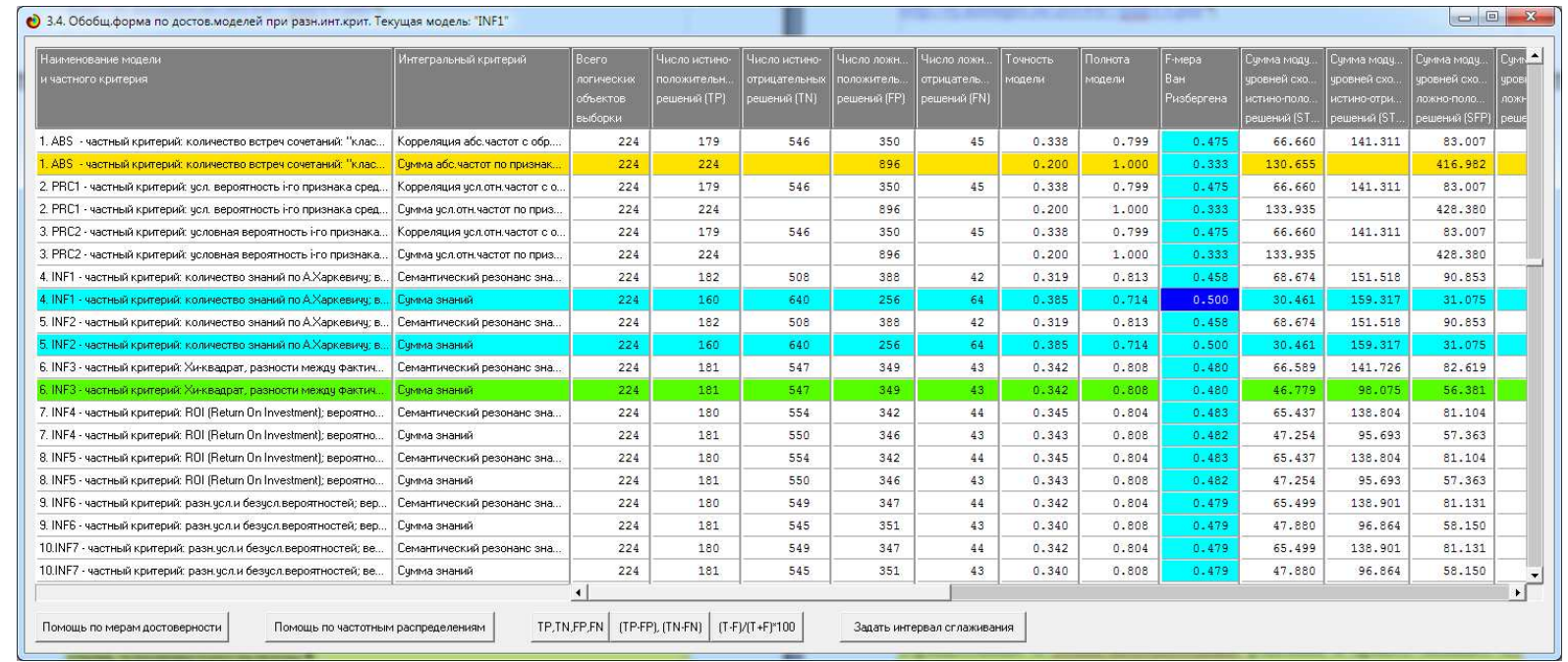

Рисунок 8. Экранная форма с информацией о достоверности моделей по F-критерию Ван Ризбергена и L1- и L2-критериям проф.Е.В.Луценко [10]

\section{Это позволяет сделать обоснованные выводы о том, что:}

1. Существует не очень сильная причинно-следственная зависимость между параметрами тензиограмм динамического поверхностного натяжения на границе раздела молоко/воздух (ДПВ) и содержанием жира и белка в коровьем молоке.

2. Эта причинно-следственная зависимость адекватно отражена в системно-когнитивных моделях INF1 и INF3.

На рисунке 9 приведено частотное распределения числа истинных и ложных положительных и отрицательных решений по результатам оценки жи на основе их морфологических свойств в СК-модели INF1 по данным обучающей выборки:

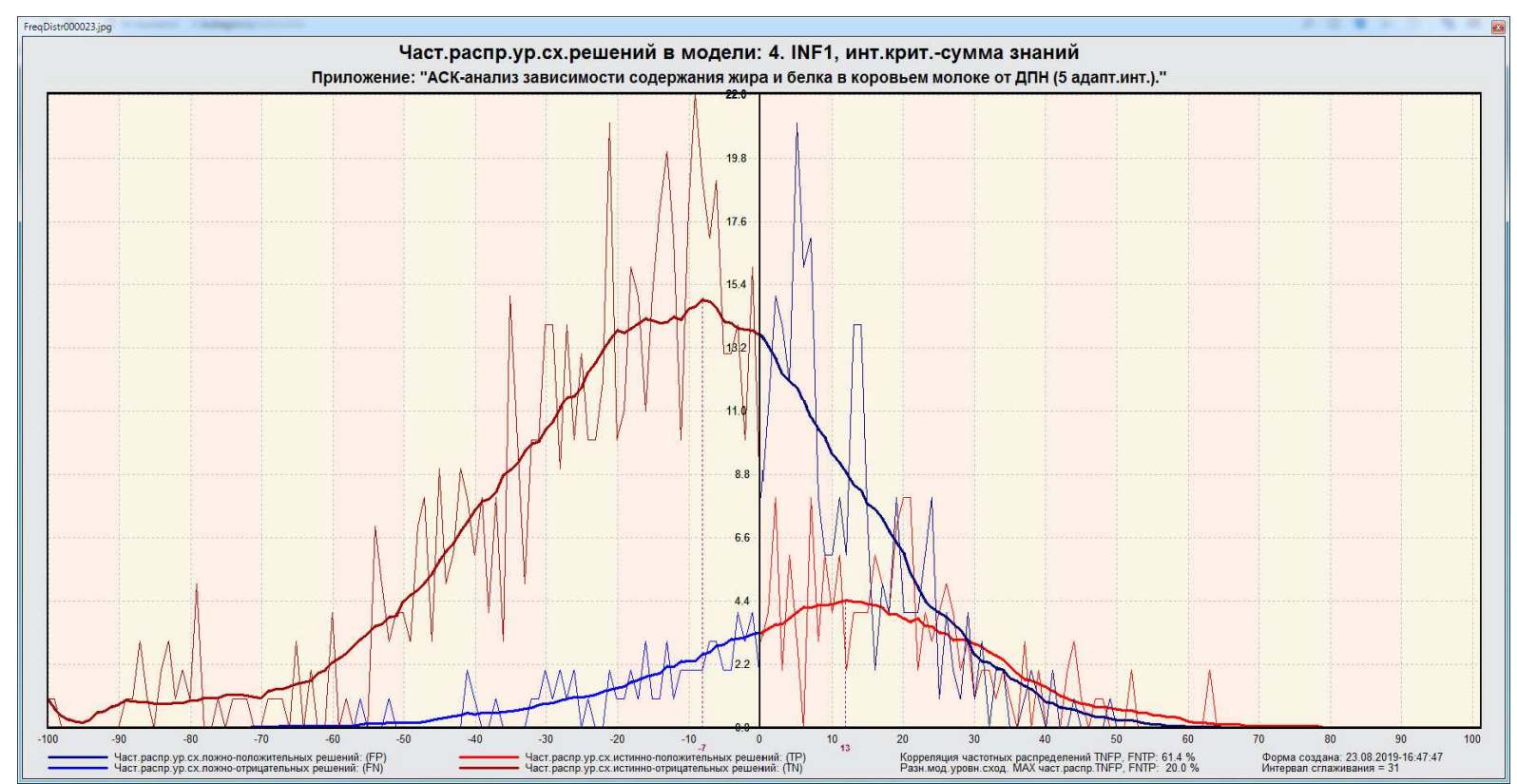

Рисунок 9. Частотные распределения числа истинных и ложных положительных и отрицательных решений и их разности в СК-модели Inf1 
Рисунок 9 содержит изображения двух частотных распределений, похожих на нормальные, сдвинутых относительно друг друга по фазе.

Левое распределение, большее по амплитуде включает истинноотрицательные и ложно-положительные решения, а правое, меньшее по амплитуде, включает ложные отрицательные и истинно-положительные решения.

Сдвиг этих распределений относительно друг друга и другие различия между ними и позволяют решать задачу идентификации содержания жира и белка в коровьем молоке по параметрам ДПВ другие задачи.

Видно, что для отрицательных решений количество истинных решений всегда значительно превосходит количество ложных решений, причем при уровнях различия больше примерно $55 \%$ ложные отрицательные решения вообще практически отсутствуют.

Видно также, что для положительных решений картина более сложная и включает 3 диапазона уровней сходства

1) при уровнях сходства от $0 \%$ до примерно $30 \%$ количество ложных решений больше числа истинных;

2) при уровнях сходства от $30 \%$ до примерно $57 \%$ есть и истинные и ложные положительные решения, но число истинных решений больше числа ложных и доля истинных решений возрастает при увеличении уровня сходства;

3) при уровнях сходства выше $57 \%$ встречаются ложных положительных решений практически не встречается.

На рисунке 10 приведен Help по режиму 3.4, в котором описаны меры достоверности моделей, применяемые в системе «Эйдос»:

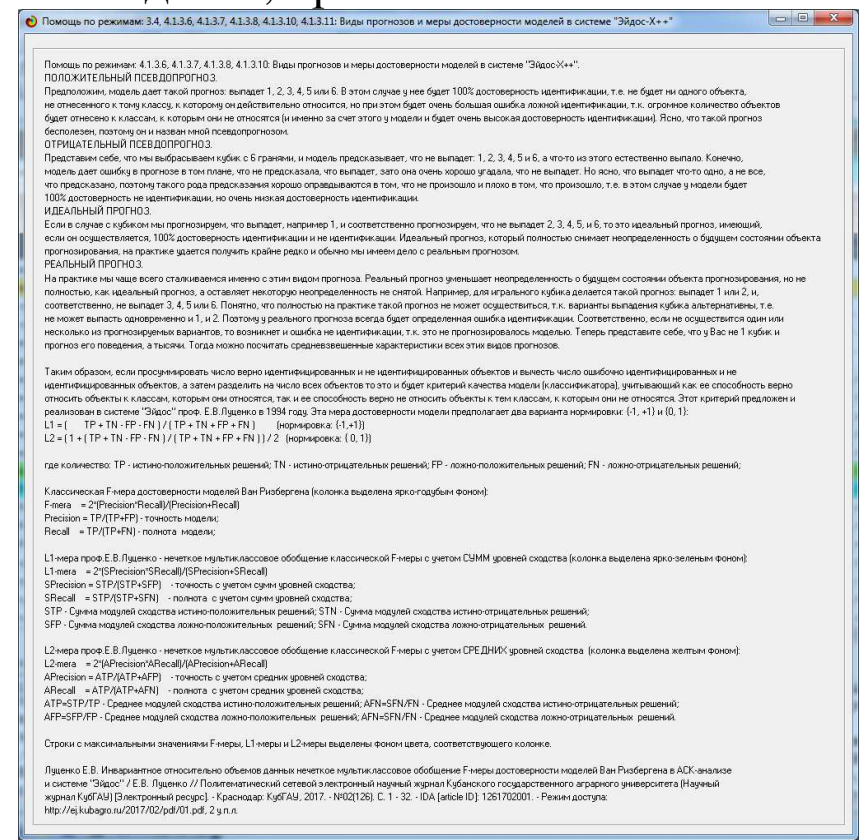

Рисунок 10. Экранная форма с информацией о достоверности моделей по F-критерию Ван Ризбергена и L1- и L2-критериям проф.Е.В.Луценко [10] 


\section{Выбор наиболее достоверной модели и присвоение ей статуса текущей}

В соответствии со схемой обработки данных, информации и знаний в системе «Эйдос» (рисунок 1), присвоим CK-модели INF1 статус текущей модели. Для этого запустим режим 5.6 с параметрами, приведенными на экранной форме (рисунок 11):

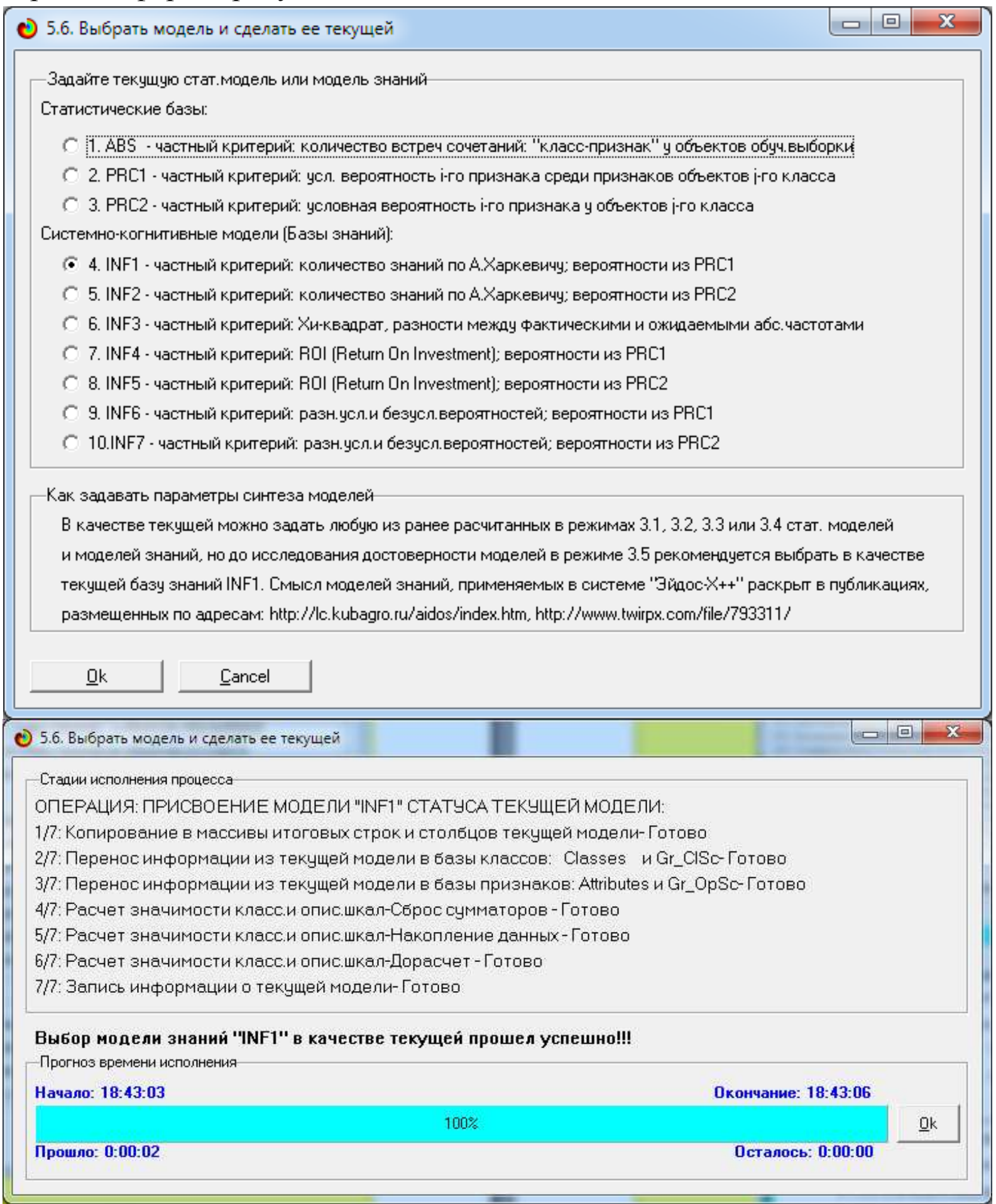

Рисунок 11. Экранные формы придания наиболее достоверной по F-критерию CK-модели Inf1 статуса текущей модели 


\section{Задача 4: решение различных задач в наиболее достоверной модели}

\section{Подзадача 4.1. Прогнозирование (диагностика, классификация, распознавание, идентификация)}

Решим задачу системной идентификации, т.е. измерения содержания жира и белка в коровьем молоке на основе обучающей выборки в наиболее достоверной СК-модели INF1 на GPU (рисунок 12).

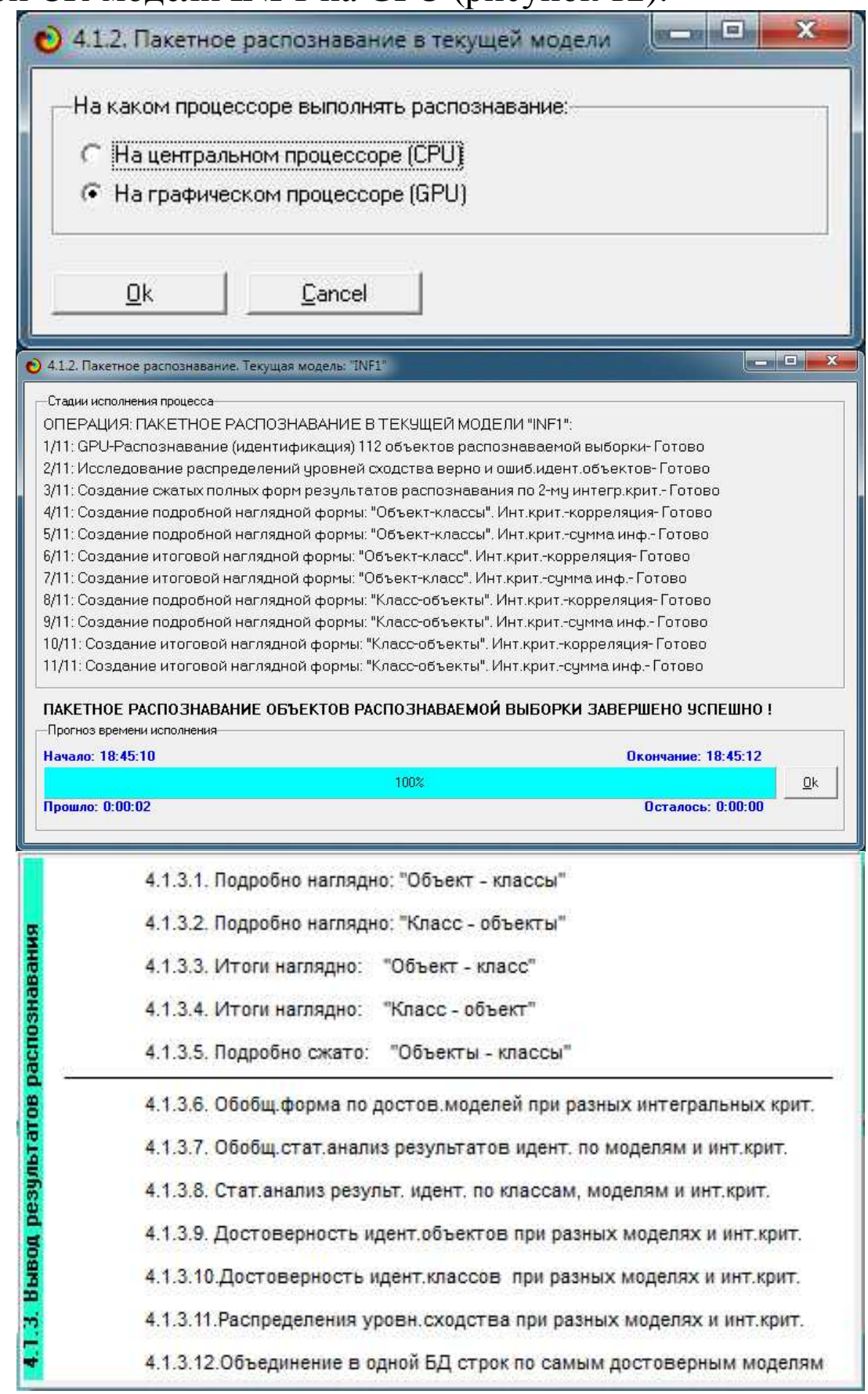

Рисунок 12. Экранные формы отображения процесса решения задачи системной идентифкации в текущей модели 
Из рисунка 11 видно, что процесс идентификации занял 2 секунды.

Отметим, что 99,999\% этого времени заняла не сама идентификация на GPU, а создание 10 выходных форм на основе результатов этого прогнозирования. Эти формы отражают результаты прогнозирования в различных разрезах и обобщениях:

Приведем две из этих 10 форм: 4.1.3.1 и 4.1.3.2 (рисунок 13).

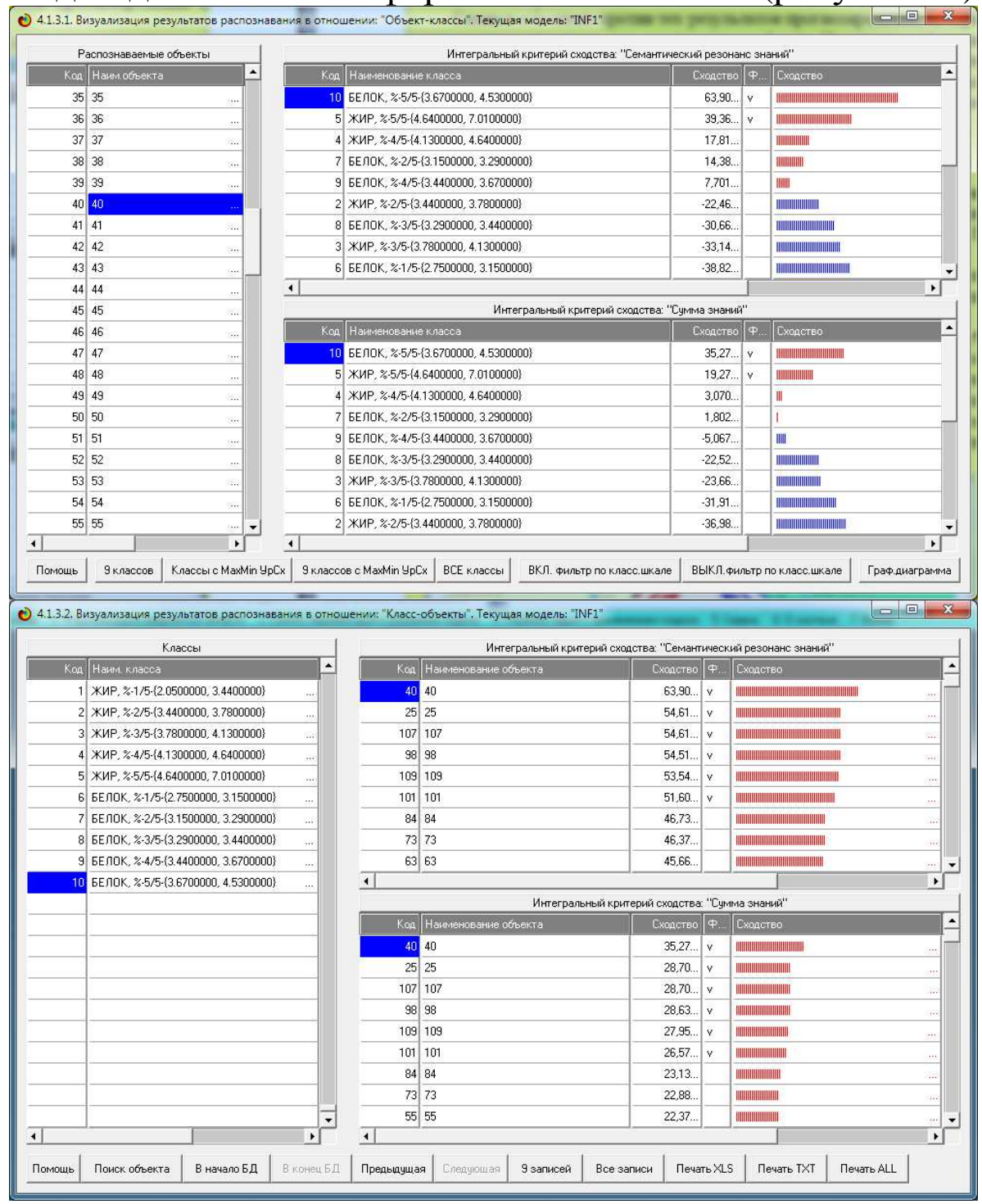

Рисунок 13. Выходные формы по результатам прогнозирования содержания жира и белка в коровьем молоке на основе значений параметров ДПН

Символ « $\sqrt{ }$ » стоит против тех результатов идентификации, которые подтвердились на опыте, т.е. соответствуют факту. Из рисунка 13 видно, что результаты идентификации являются хорошими, естественно при учете информации из рисунка 9 о том, что достоверные прогнозы в данной модели имеют уровень сходства выше $57 \%$, т.е. по сути результаты с более низки уровнем сходства надо просто игнорировать. 


\section{Подзадача 4.2. Поддержка принятия решений (SWOT-анализ)}

При принятии решений определяется сила и направление влияния значений факторов на принадлежность состояний объекта моделирования к тем или иным классам, соответствующим различным будущим состояниям. По сути это решение задачи SWOT-анализа [11].

Применительно к задаче, решаемой в данной работе, SWOT-анализ показывает степень влияния различных значений параметров ДПН на содержание жира и белка в коровьем молоке.

В системе «Эйдос» в режиме 4.4.8 поддерживается решение этой задачи. При этом выявляется система детерминации заданного класса, т.е. система значений факторов, обуславливающих переход объекта моделирования и управления в состояние, соответствующее данному классу, а также препятствующих этому переходу.

На рисунках 14 приведены SWOT-диаграммы наглядно отражающие силу и направление влияния различных значений параметров ДПН на содержание жира и белка в коровьем молоке.

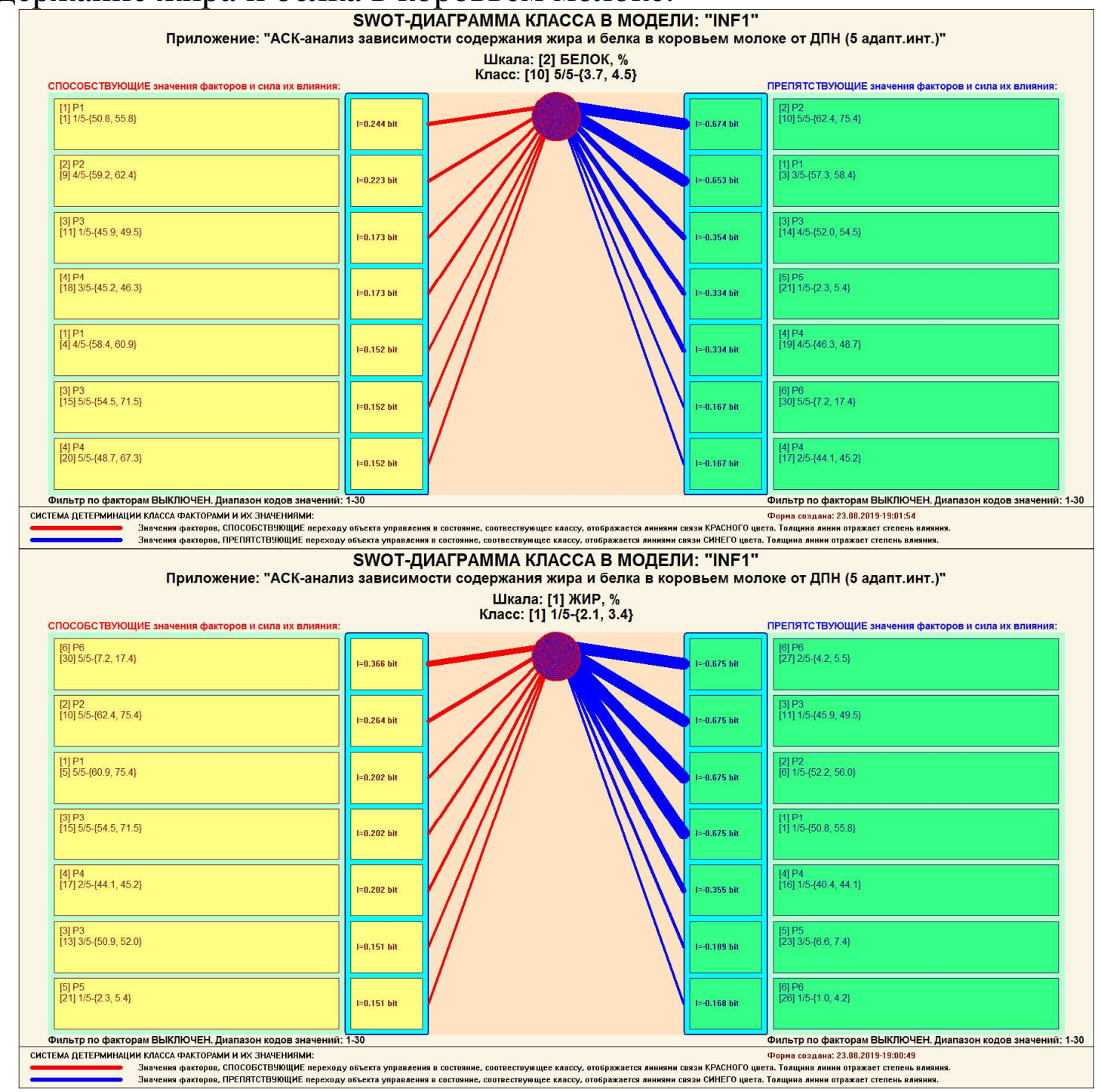



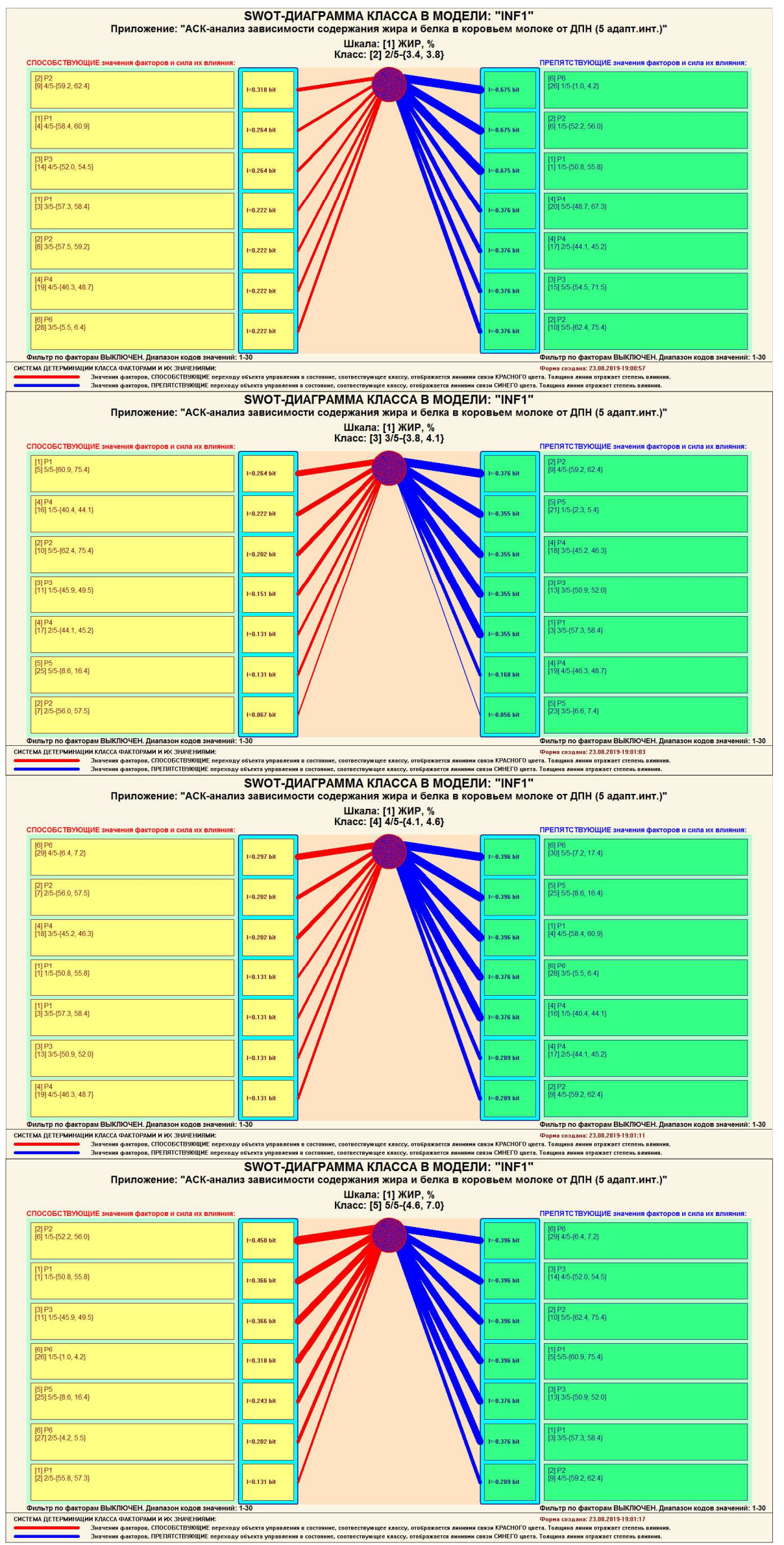

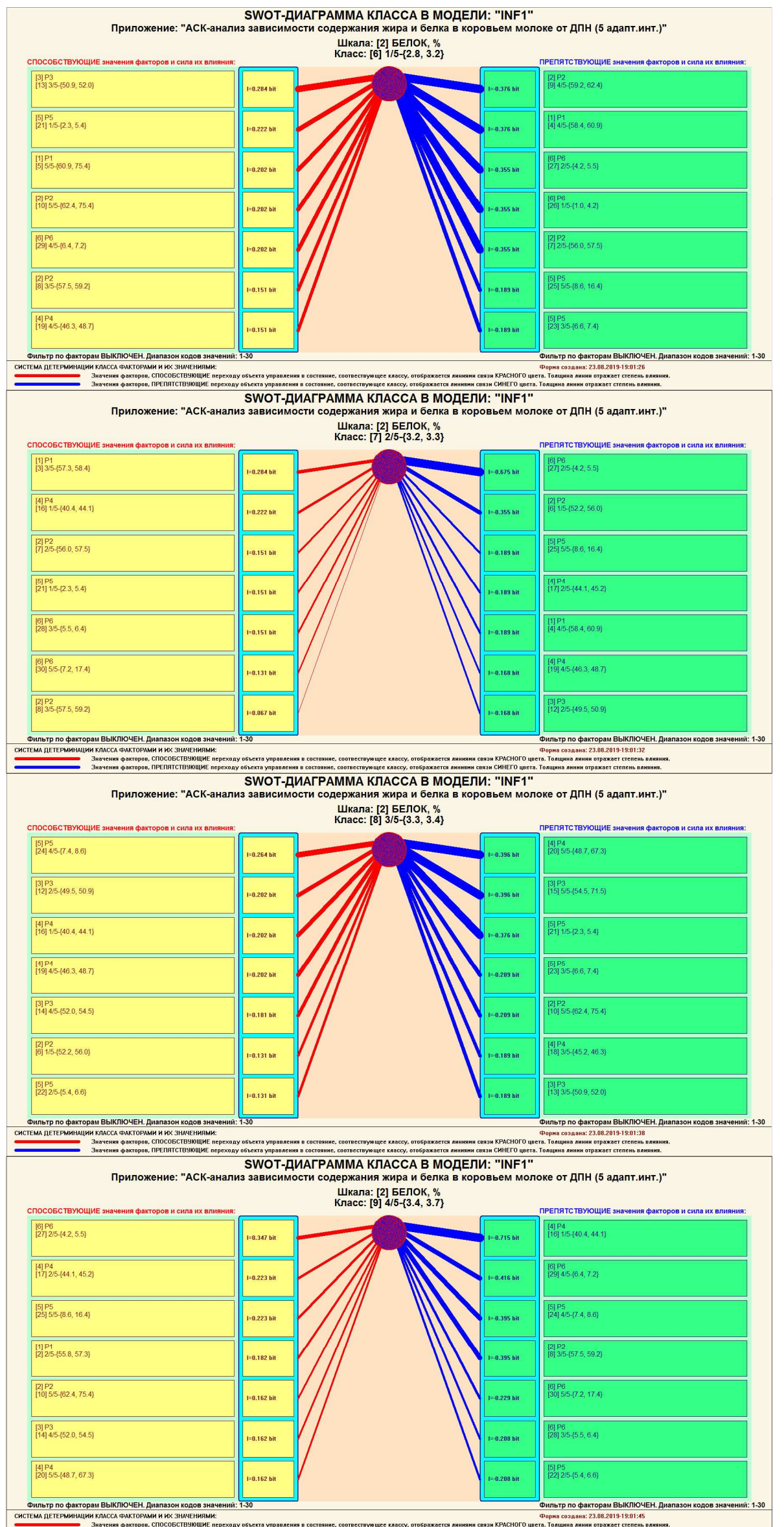

Рисунок 14. SWOT-диаграммы детерминации качества молока 
Эти SWOT-диаграммы наглядно отражают силу и направление влияния различных значений параметров ДПН на содержание жира и белка в коровьем молоке.

Отметим также, что система «Эйдос» обеспечивала решение этой всегда, т.е. даже в самых ранних DOS-версиях и в реализациях системы «Эйдос» на других языках и типах компьютеров. Например, первый акт внедрения системы «Эйдос», где об этом упоминается в явном виде, датируется 1987 годом, а первый подобный расчет относится к 1981 году.

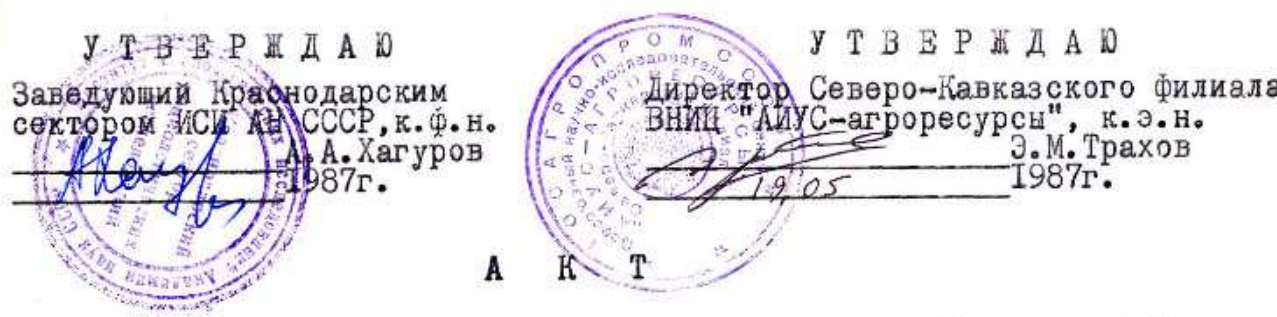

Настоящй акт составлен комиссией в составе: Кириченко М.М., Лянко Г.А., Самсонов Г.А., Коренец В.И., Луценко Е.В. в том, что в соответствии с договором о научно-техническом сотрудничестве между Сезеро-Кавказ сии филиалом ВНИЦ "АИУС-агроресурсы" И Краснодарским сектором Института социологических исследований АН СССР СевероКазказским филиалом ВНИЦ "АИУС-агроресурсы" выполнены следующие работи:

- осуществлена постановка задачи: "обработка на ЭВМ социологических анкет Крайагропрома";

- разработаны математическая модель и программное обеспечение подсистемы распознавания образов, позволяюние решать данную задачу в среде персональной технологической системы ВЕГА-М;

- на профессиональной персональной ЭВМ "Искра-226" осуществлени расчёты по задаче в объёме:

Входная информация составила 425 анкет по 9-ти предприятиям. Выходная информация - 4 вида выходных форм объёом 90 листов Формата АЗ и 20 листов формата А4 содержит:

- процентное распределение ответов в разрезе по социальным типам корреспондентов;

- распределение информатинностей признаков (в битах) для распознавания социальных типов корреспондентов;

- позитивные и негативные информационные портреты 30-ти социальных типов на язнке 2І2 признаков;

- обобщённая характеристика информативности признаков для выбора такого минимального набора признаков, который содержит максимум информации о распознаваемых объектах (оптимизация анкет)。

Работы выполнены на высоком научно-методическом уровне и в срок.

OT ИСИ АН СССР:

Мл.научннй сотрудник

Duf M.м. Кириченко

1905 I 987 .

Мл. научный сотрудник

Lomere $\Gamma$. A. JЯ

$19.051987 \mathrm{r}$.
От СКФ ВНИЦ "АИУС-агроресурсы": Зав.отделом аэрокосмических и тематуческих ивысканий $64, \mathrm{k}$. э.н. tanceues $\Gamma$. A. Самсонов $\frac{19.05}{19} \mathrm{I}$. $97 \mathrm{r}$. Главны констриктор проекта - volelles 3.K. Коренец $-\frac{150587_{2}}{15087 \mathrm{r}}$

Главный конетруктор проекта

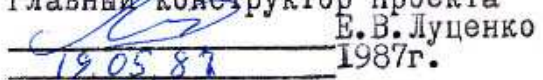


Но тогда SWOT-диаграммы назывались позитивным и негативным информационными портретами классов.

Информация о системе значений факторов, обуславливающих переход объекта моделирования в различные будущие состояния, соответствующие классам, может быть приведена не только в диаграммах, показанных на рисунках 14, но и во многих других табличных и графических формах, которые в данной работе не приводятся только из-за ограниченности ее объема. В частности в этих формах может быть выведена значительно более полная информация (в т.ч. вообще вся имеющая в модели). Подобная подробная информация содержится в базах данных, расположенных по пути: c:\Aidos-

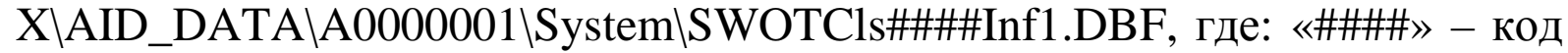
класса с ведущими нулями. Эти базы открываются в MS Excel.

На рисунке 15 приведены примеры нескольких инвертированных SWOT-диаграмм, отражающих силу и направление влияния различных значений параметров ДПН коровьего молока на содержание в нем жира и белка:

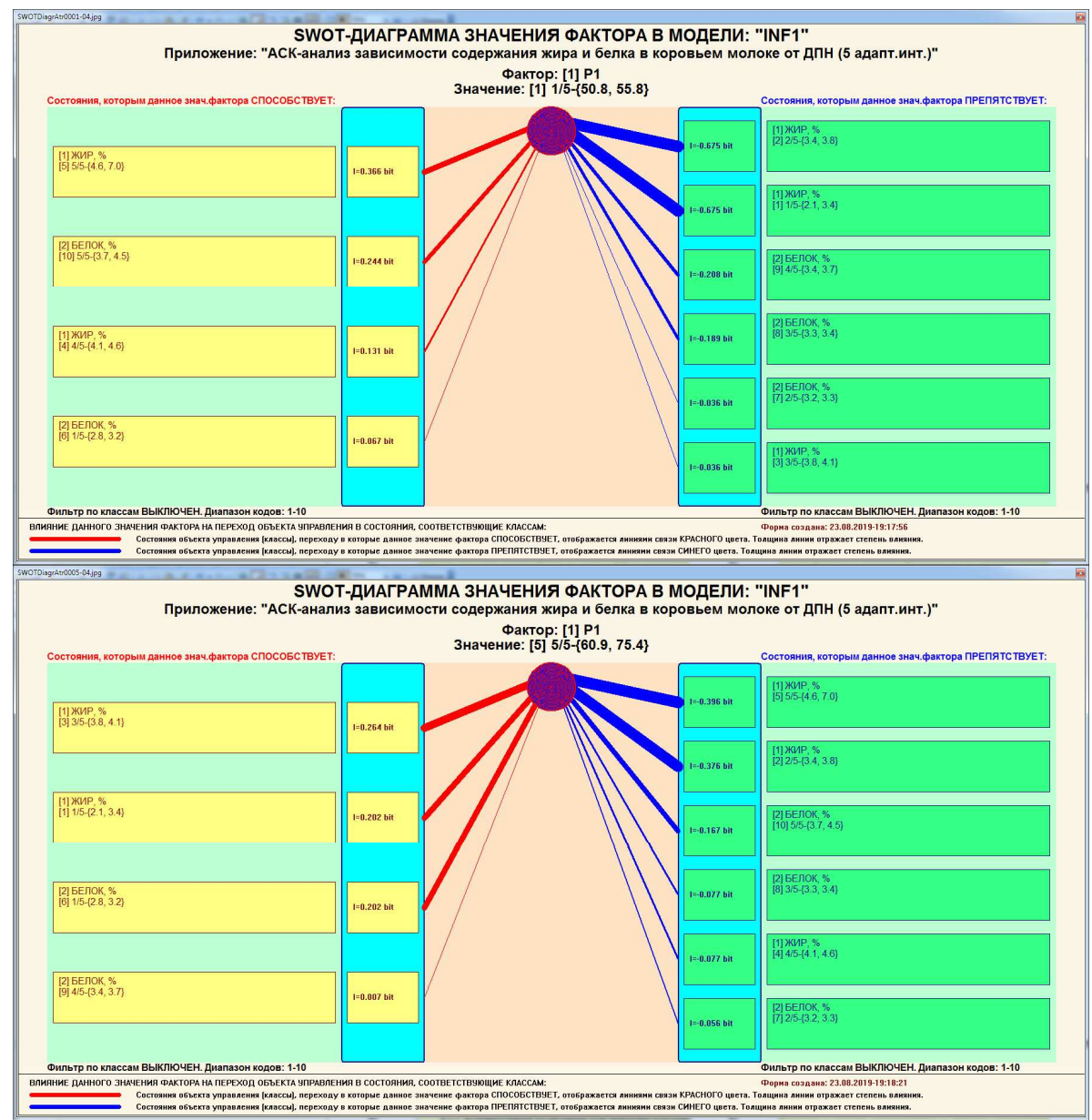

Рисунок 15. Примеры SWOT-диаграмм, отражающих силу и направление влияния конкретного значения параметра ДПН на содержание жира и белка в коровьем молоке 
Из рисунка 15 видно, как очень низкое значение параметра ДПН Р1 детерминирует очень высокое содержание жира и белка в коровьем молоке.

В заключение отметим, что SWOT-анализ является широко известным и общепризнанным метод стратегического планирования. Однако это не мешает тому, что он подвергается критике, часто вполне справедливой, обоснованной и хорошо аргументированной. В результате критического рассмотрения SWOT-анализа выявлено довольно много его слабых сторон (недостатков), источником которых чаще всего является необходимость привлечения экспертов, в частности для оценки силы и направления влияния факторов. Ясно, что эксперты это делают неформализуемым путем (интуитивно), на основе своего опыта и профессиональной компетенции. Но возможности экспертов имеют свои ограничения и часто по различным причинам они не могут и не хотят это сделать. Таким образом, возникает проблема проведения SWOT-анализа без привлечения экспертов. Эта проблема может решаться путем автоматизации функций экспертов, т.е. путем измерения силы и направления влияния факторов непосредственно на основе эмпирических данных. Подобная технология разработана давно, ей уже более 30 лет, но к сожалению она сравнительно малоизвестна - это интеллектуальная система «Эйдос» $[11,18,19]$.

\section{Подзадача 4.3. Исследование моделируемой предметной области путем исследования ее модели}

Если модель предметной области достоверна, то исследование модели можно считать исследованием самого моделируемого объекта, т.е. результаты исследования модели корректно относить к самому объекту моделирования, «переносить на него».

В системе «Эйдос» есть довольно много возможностей для такого исследования, но в данной работе из-за ограничений на ее объем мы рассмотрим лишь результаты кластерно-конструктивного анализа классов и признаков (когнитивные диаграммы и дендрограммы), а также нелокальные нейроны, нелокальные нейронные сети, 3d-интегральные когнитивные карты и когнитивные функции.

\subsection{1. Когнитивные диаграммы классов}

Эти диаграммы отражают сходство/различие классов. Мы получаем их в режимах 4.2.2.1 и 4.2.2.2 (рисунок 16).

Отметим также, что на когнитивной диаграмме, приведенной на рисунке 16, показаны количественные оценки сходства/различия таких важнейших показателей качества коровьего молока как содержание жира и белков, по связанным с ними значениям параметров ДПН. Важно, что эти 
результаты сравнения получены с применением системно-когнитивной модели, созданной непосредственно на основе эмпирических данных, а не как традиционно делается на основе экспертных оценок неформализуемым путем на основе опыта, интуиции и профессиональной компетенции.

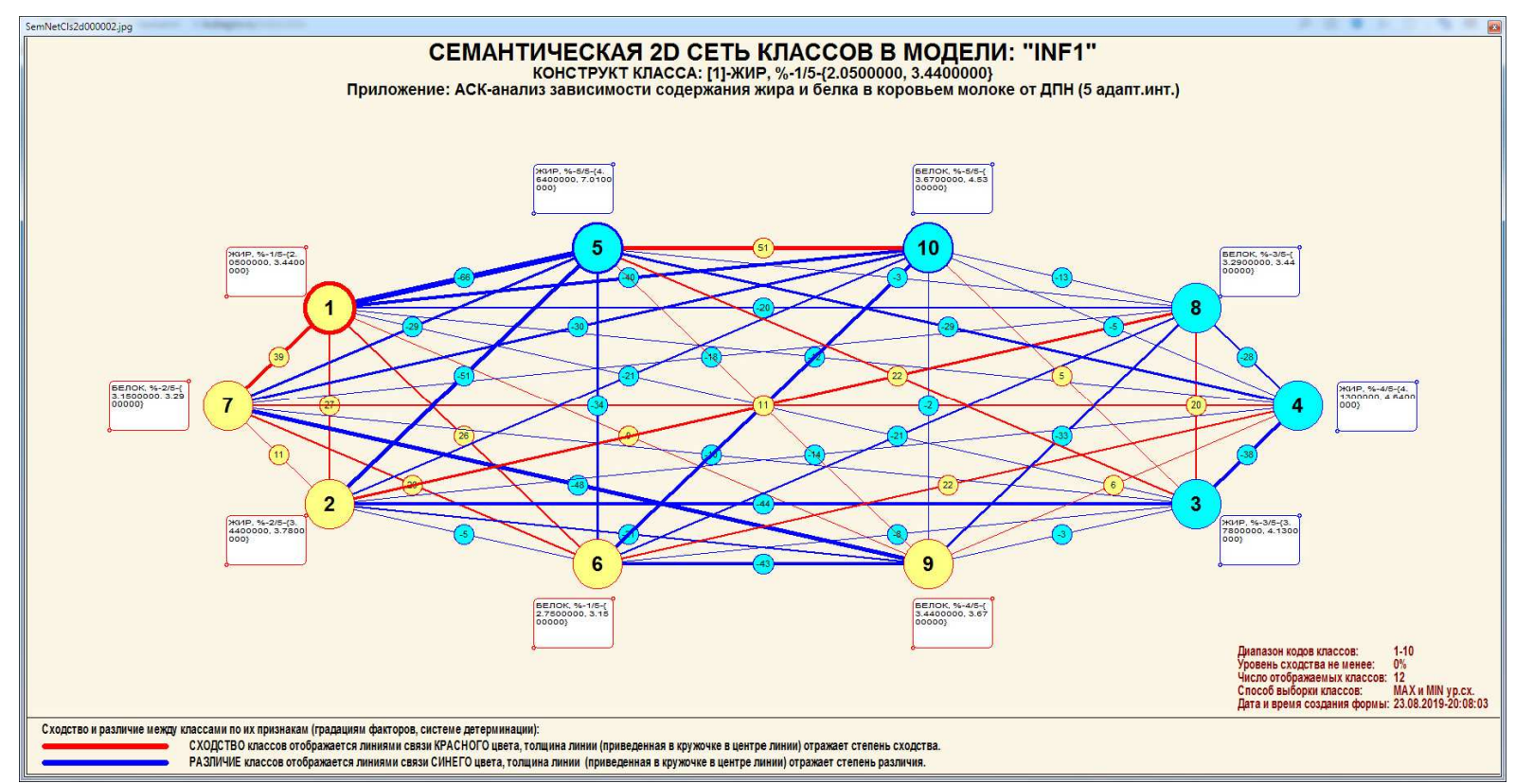

Рисунок 16. Когнитивная диаграмма классов, отражающая сходство/различие коровьего молока различного качества (содержанием жира и белков), по связанным с ними значениям параметров ДПН

В системе «Эйлос» есть возможность управлять параметрами формирования и вывода изображения, приведенного на рисунке 16. Для этого используется диалоговое окно, приведенное на рисунке 17.

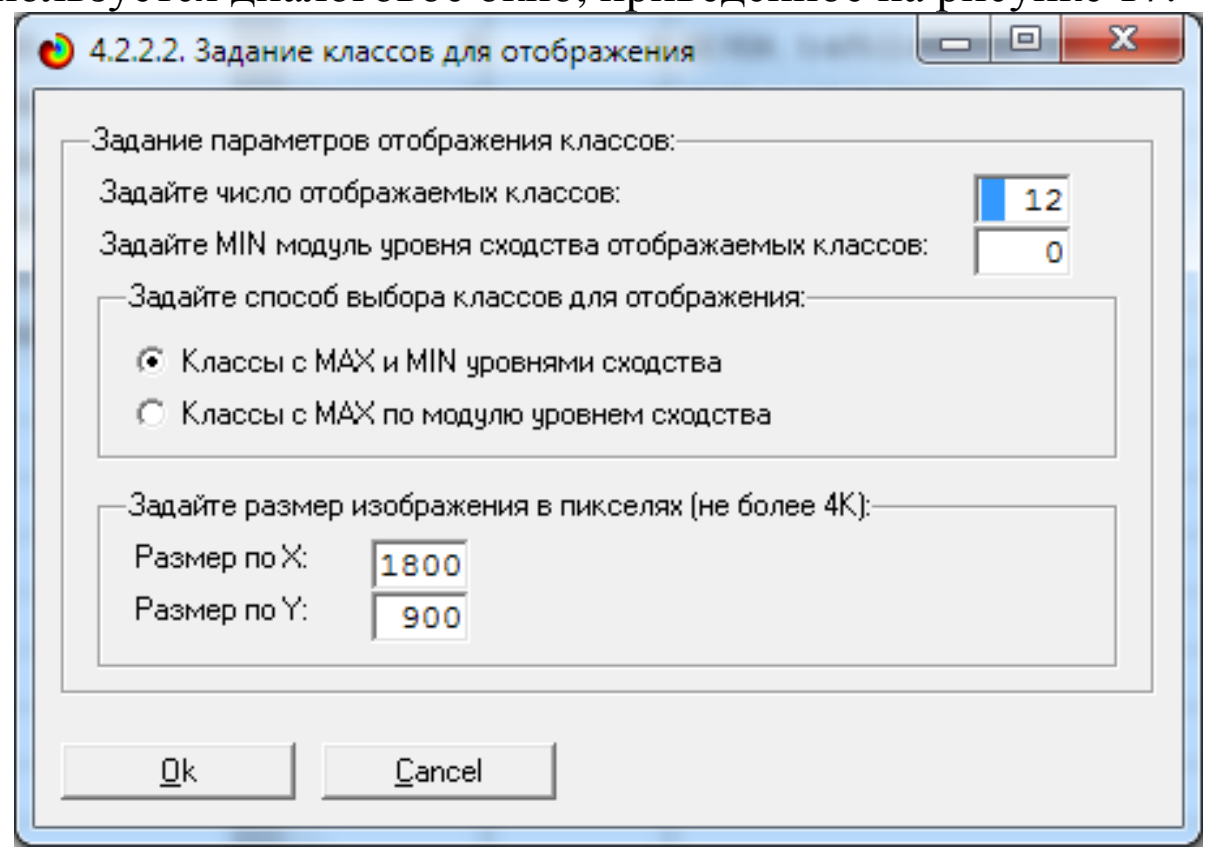

Рисунок 17. Диалоговое окно управления параметрами формирования и вывода изображения когнитивной диаграммы классов 


\subsection{2. Агломеративная когнитивная кластеризация классов}

Информация о сходстве/различии классов, содержащаяся в матрице сходства, может быть визуализирована не только в форме, когнитивных диаграмм, пример которой приведен на рисунке 16, но и в форме агломеративных дендрограмм, полученных в результате когнитивной кластеризации [5] (рисунок 18):

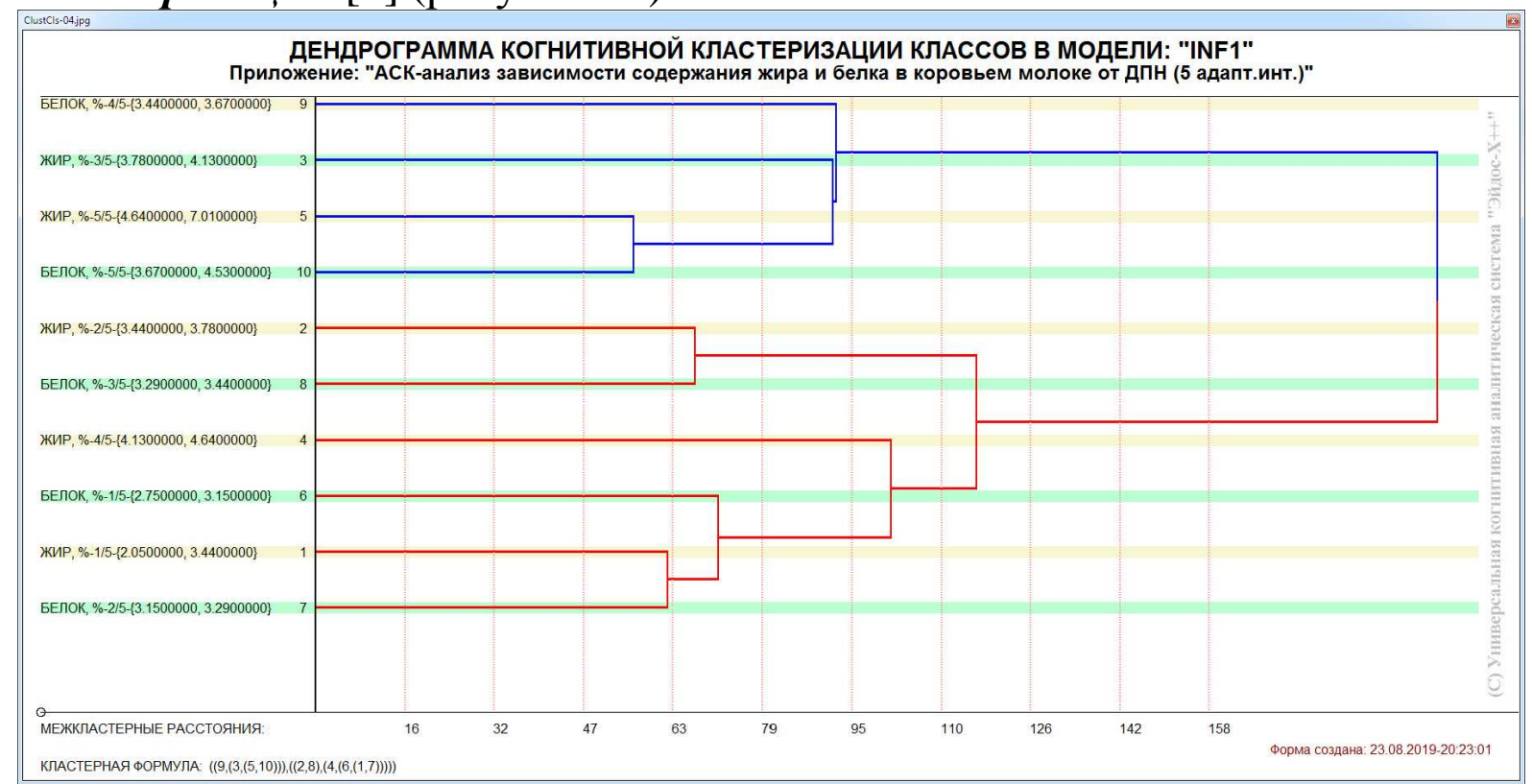

Рисунок 18. Дендрограмма когнитивной агломеративной кластеризации, отражающая сходство/различие коровьего молока различного качества, по связанным с ним значениям параметров ДПН

Из рисунков 16 и 18 мы видим, что некоторые показатели качества коровьего молока сходны по детерминирующей их системе значений параметров ДПН, и, следовательно, корректно ставить задачу их одновременного достижения, а другие по системе значений этих параметров сильно отличаются, и, следовательно, являются взаимоисключающими, т.е. альтернативными и цель их одновременного достижения является некорректной и недостижимой, т.к. для достижения одного из альтернативных результатов необходимы одни значения параметров ДПН, а для достижения другого - совершенно другие, которые не могут наблюдаться одновременно с первыми.

Из дендрограммы когнитивной агломеративной кластеризации классов, приведенной на рисунке 18 , мы видим также, что все классы по качеству молока образуют два противоположных кластера, являющихся полюсами конструкта, по системе значений обуславливающих значениям параметров ДПН.

В верхнем кластере объединены (за редким исключением) результаты с очень высокими, высокими и средними значениями показателей качества, а в нижнем - с очень низкими, низкими и средними. 
Исключением является высокое содержание жира, попавшее в нижний кластер, и среднее - попавшее в верхний.

Из этого можно сделать вывод о том, что высокие и очень высокие показатели качества молока по содержанию жиров и белков обычно наблюдаются в одних и тех же пробах и достижимы одновременно, как и очень низкие, низкие и средние показатели качества.

Отметим однако, что в наших исходных данных нет информации об удоях, в которых получены приведенные пробы. Авторы могут предположить, что высокие удои отрицательно сказываются на качестве молока, а низкие положительно, т.е. по сути повышение удоев достигается просто путем содержания воды в молоке при примерно том же содержании белков и жиров.

Отметим, что аналогичная картина наблюдается не только в животноводстве, но в птицеводстве, и в растениеводстве, причем не только по овощным, но и по фруктовым, и по зерновым культурам. При этом высокие финансово-экономические показатели по системе детерминирующих их факторов обычно сходны с высокими количественными результатами и низкими качественными, т.е. высокие прибыль и рентабельность обуславливаются в основном большим количеством продукции, а не ее высоким качеством.

На рисунке 19 мы видим график изменения межкластерных расстояний:

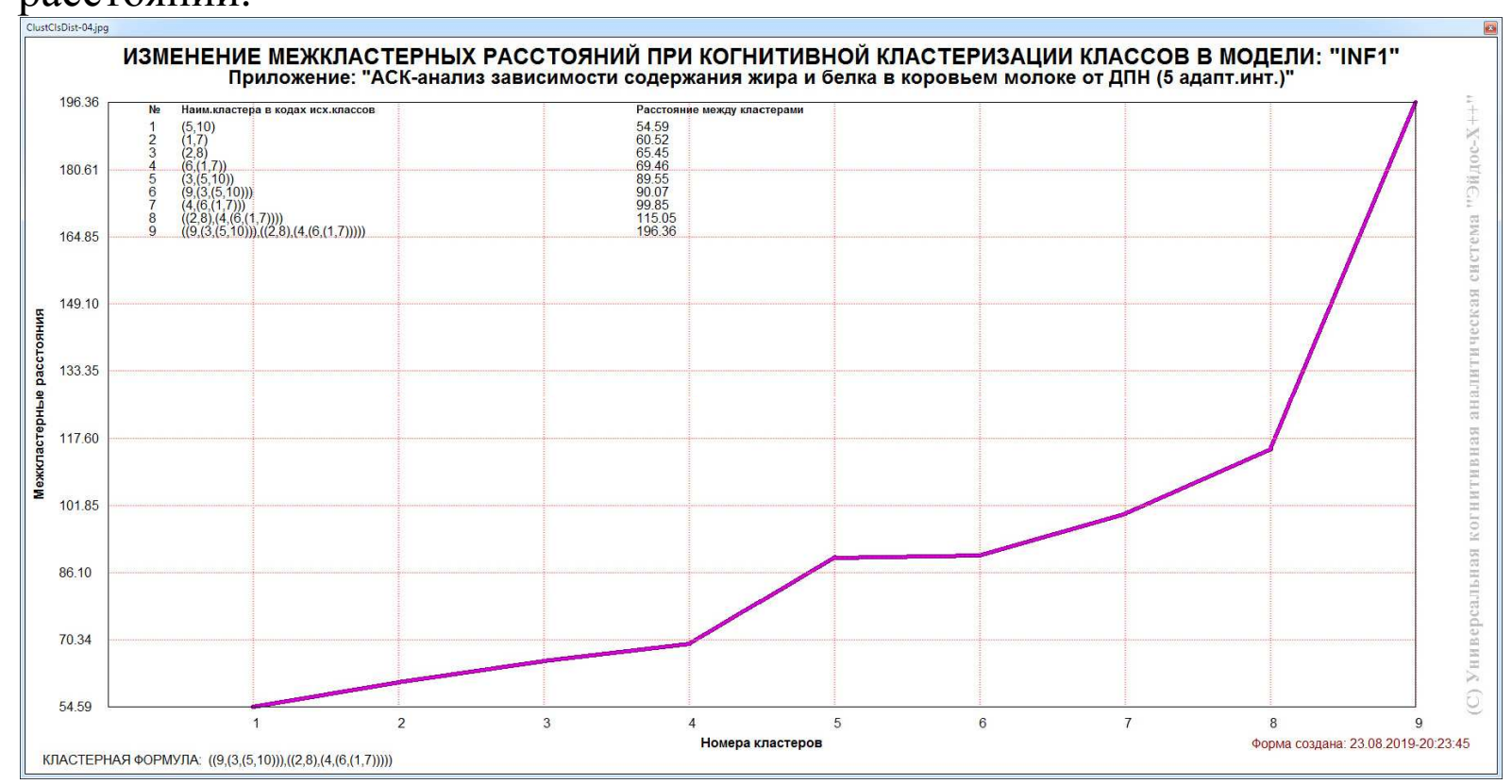

Рисунок 19. График изменения межкластерных расстояний

\subsection{3. Когнитивные диаграммы значений фракторов}

Эти диаграммы отражают сходство/различие значений параметров ДПН по их смыслу, т.е. по содержащейся в них информации о качестве коровьего молока (содержании в нем жиров и белков). Эти диаграммы мы получаем в режимах 4.3.2.1 и 4.3.2.2 (рисунок 20). 


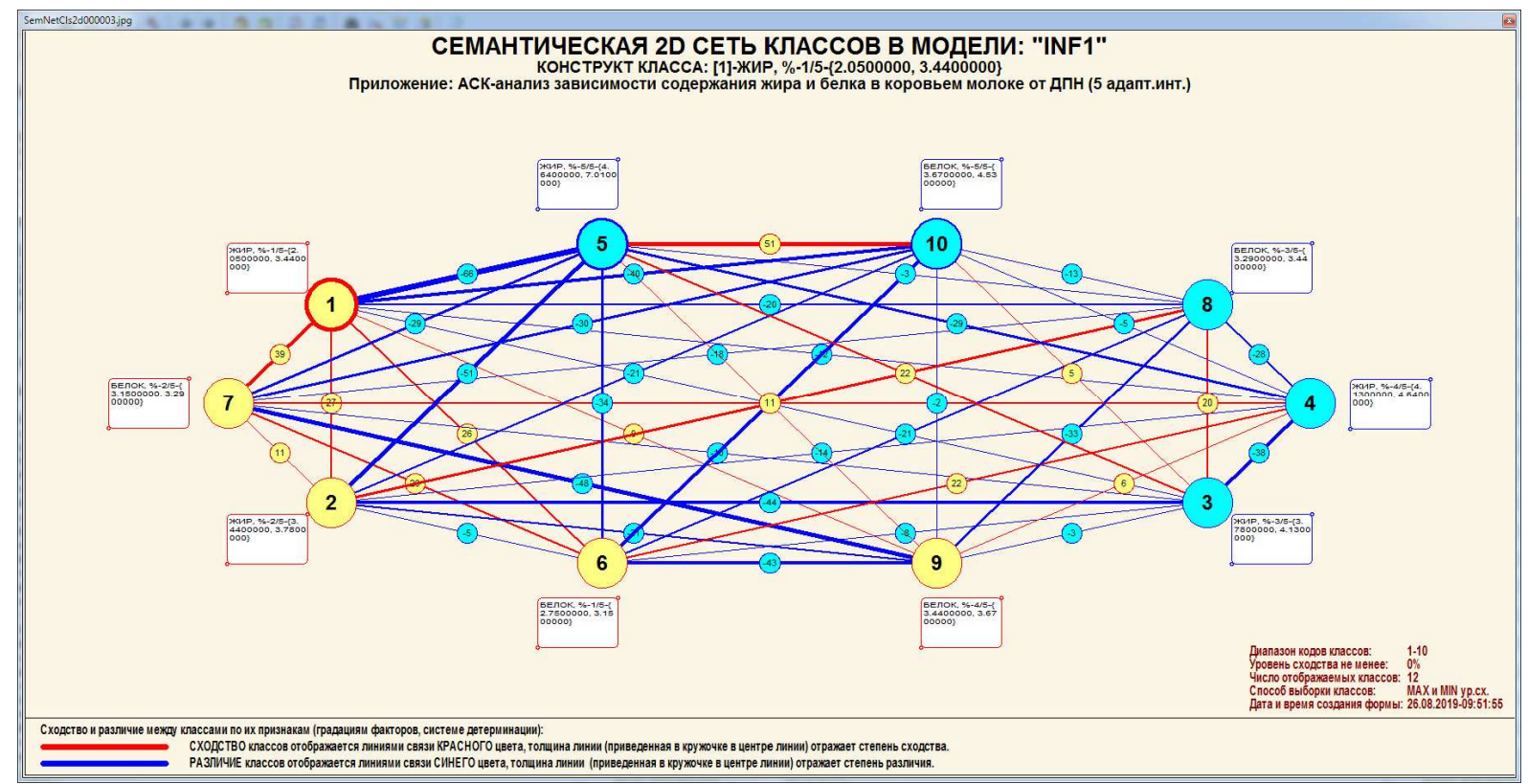

Рисунок 20. сходство/различие значений параметров ДПН по их смыслу, т.е. по содержащейся в них информации о качестве коровьего молока

Из рисунка 20 видно, что все значения факторов образуют два крупных кластера, противоположных по их смыслу. Эти кластеры образуют полюса конструкта.

Отметим, что на когнитивной диаграмме, приведенной на рисунке 20, показаны количественные оценки сходства/различия значений факторов, полученные с применением системно-когнитивной модели, созданной непосредственно на основе эмпирических данных, а не как традиционно делается на основе экспертных оценок неформализуемым путем на основе опыта, интуиции и профессиональной компетенции.

Диаграмма, приведенная на рисунке 20, получена при параметрах, приведенных на рисунке 21.

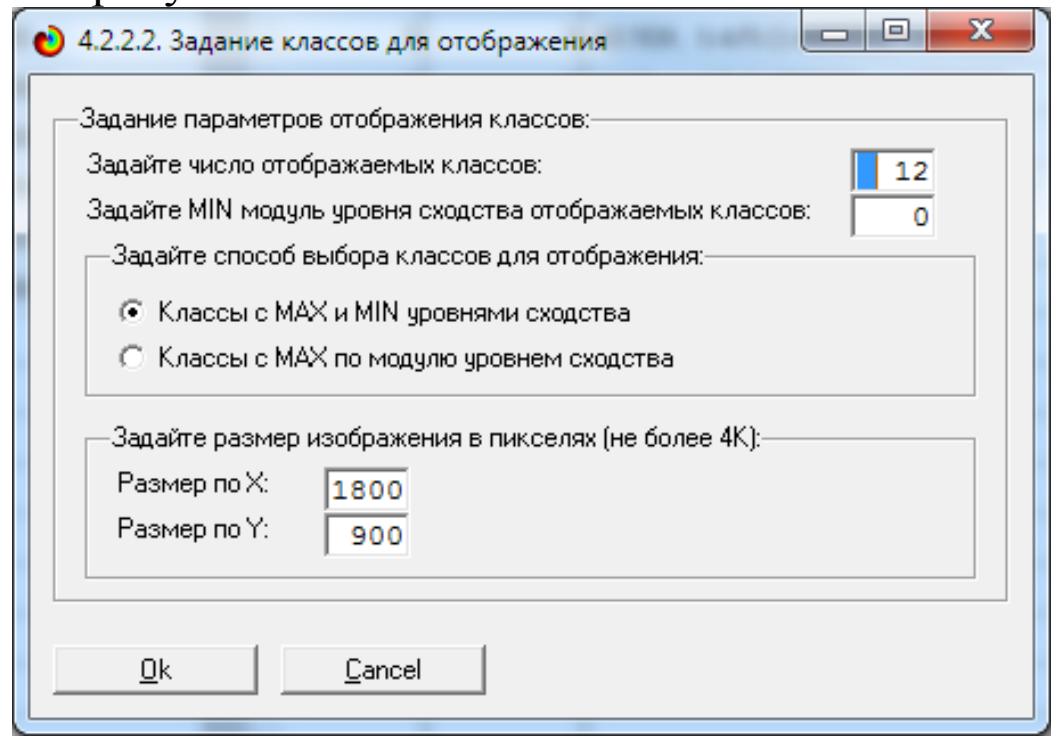

Рисунок 21. Параметры отображения когнитивной диаграммы, приведенной на рисунке 20 


\subsection{4. Агломеративная когнитивная кластеризация значений факторов}

На рисунке 22 приведена агломеративная дендрограмма когнитивной кластеризации значений факторов и график изменения межкластерных расстояний, полученные на основе той же матрицы сходства признаков по их смыслу, что и в когнитивных диаграммах, пример которой приведен на рисунке 20.

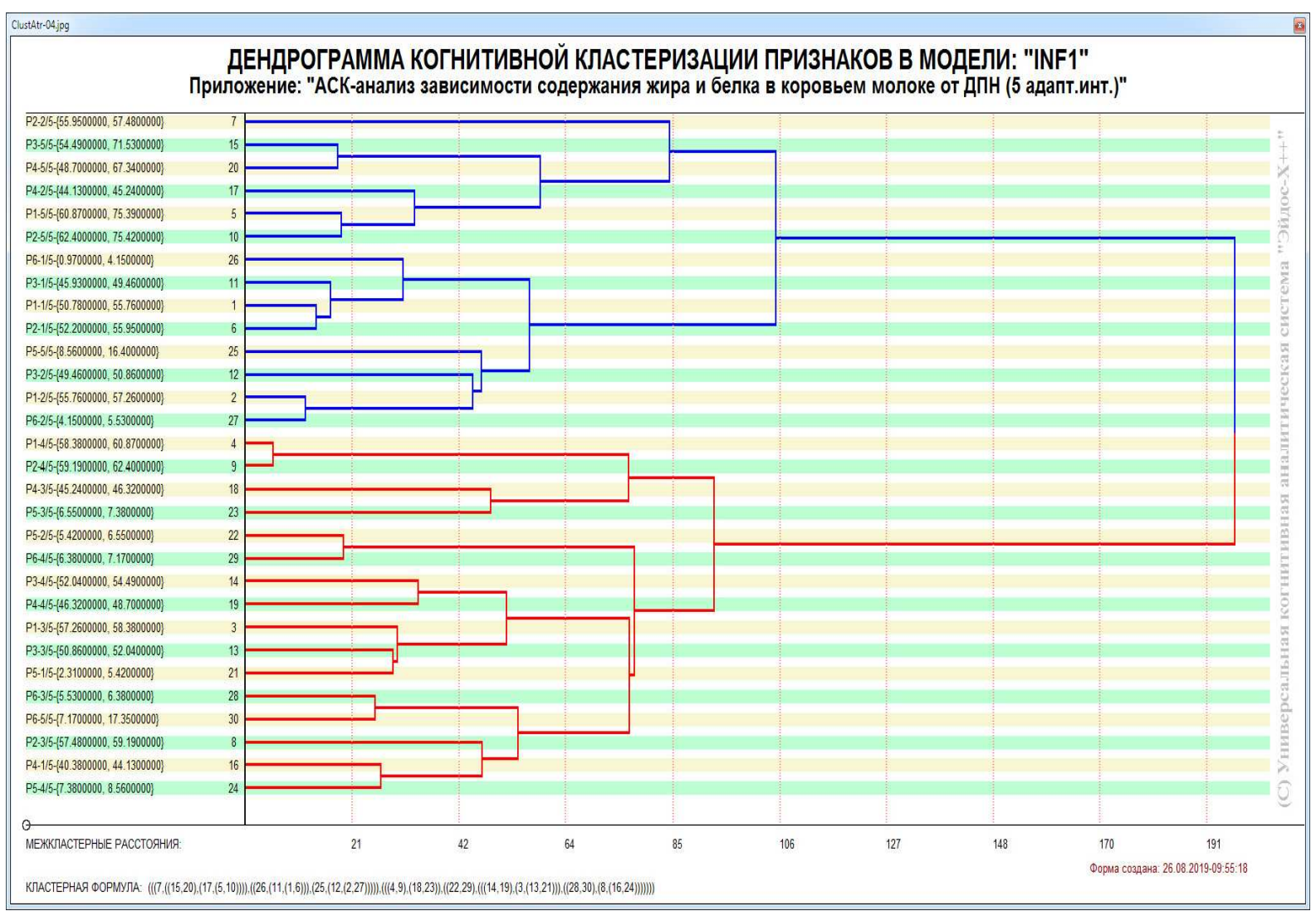

Рисунок 22. Дендрограмма агломеративной когнитивной кластеризации значений параметров ДПН по их смыслу, т.е. по содержащейся в них информации о качестве коровьего молока

Из дендрограммы на рисунке 22 мы видим, что все значения факторов образуют 2 четко выраженных кластера, объединенных в полюса конструкта (показаны синими и красным цветами).

Хорошо видна группировка значений параметров ДПН по их смыслу, т.е. по содержащейся в них информации о качестве коровьего молока. Значения факторов на полюсах конструкта факторов (рисунок 22) обуславливают переход объекта моделирования в состояния, соответствующие классам, представленным на полюсах конструкта классов (рисунки 18 и 20).

На рисунке 23 приведен график межкластерных расстояний значений параметров ДПН коровьего молока. 


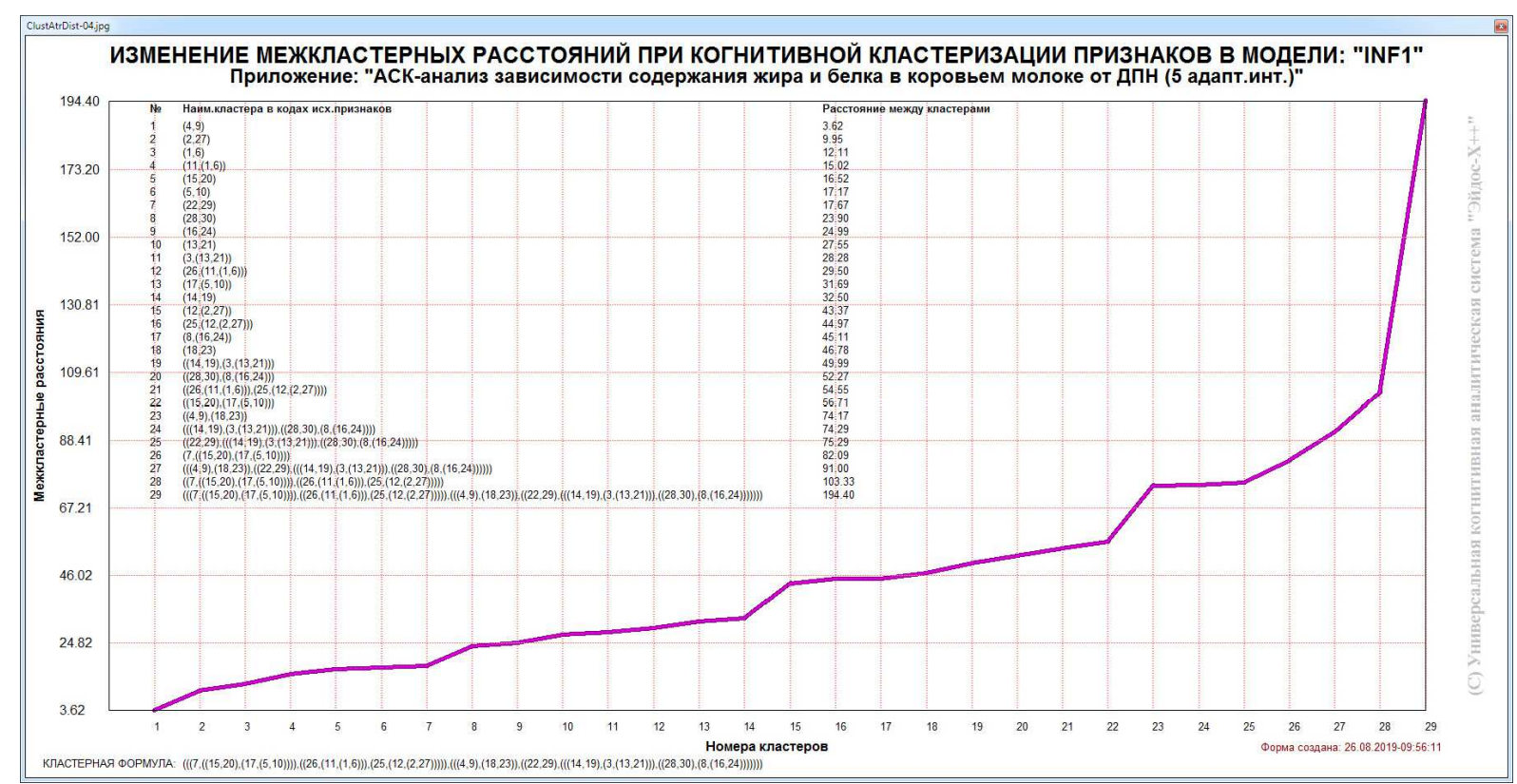

Рисунок 23. График изменения межкластерных расстояний при когнитивной кластеризации значений факторов

\subsection{5. Нелокальные нейроны и нелокальные нейронные сети}

На рисунке 24 приведены пример нелокального нейрона, а на рисунке 25 и фрагмент одного слоя нелокальной нейронной сети:

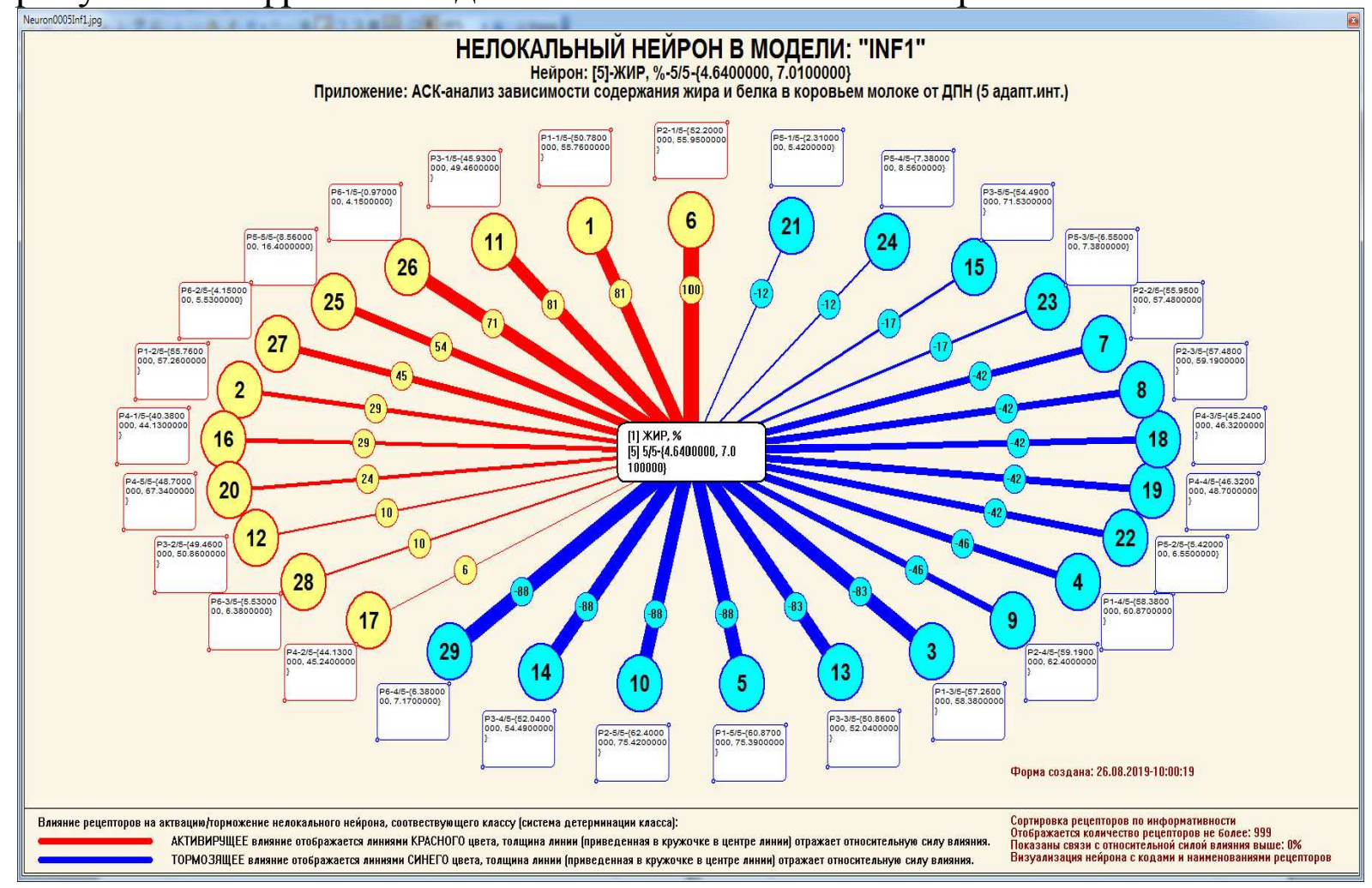

Рисунок 24. Пример нелокального нейрона, отражающего силу и направление влияния значений параметров ДПН на качество коровьего молока 


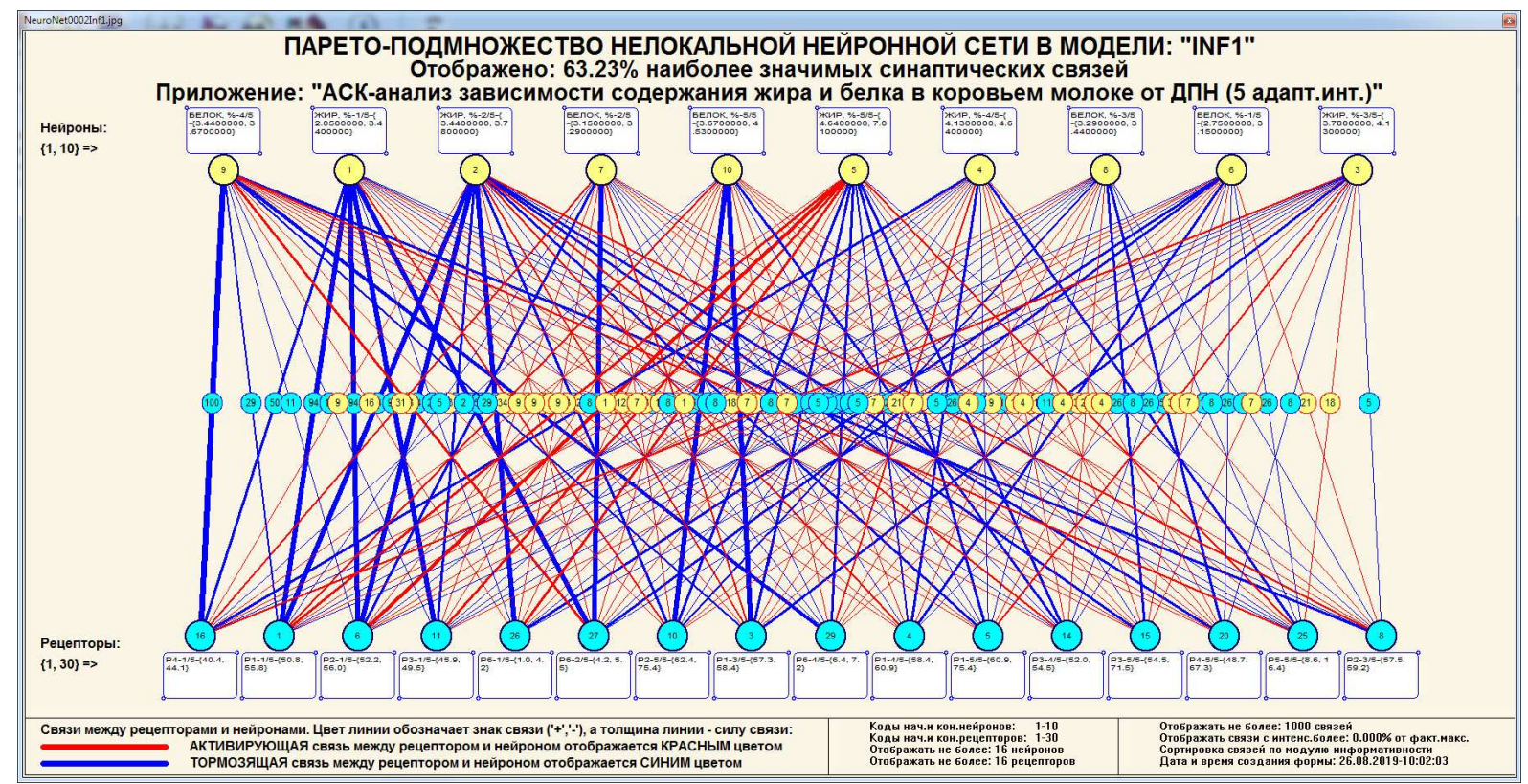

Рисунок 25. Один слой нелокальной нейронной сети, отражающий силу и направление влияния значений параметров ДПН на качество коровьего молока (фрагмент около 63\% сети)

В приведенном фрагменте слоя нейронной сети нейроны соответствуют показателям качества коровьего молока (содержанию в нем жира и белка), а рецепторы - значения параметров ДПН. Нейроны расположены слева на право в порядке убывания силы детерминации, т.е. слева находятся результаты, наиболее жестко обусловленные обуславливающими их значениями факторами, а с права - менее жестко обусловленные.

Модель знаний системы «Эйдос» относится к нечетким декларативным гибридным моделям и объединяет в себе некоторые особенности нейросетевой $[13,20]$ и фреймовой моделей представления знаний [20]. Классы в этой модели соответствуют нейронам и фреймам, а признаки рецепторам и шпациям (описательные шкалы - слотам).

От фреймовой модели представления знаний модель системы «Эйдос» отличается своей эффективной и простой программной реализацией, полученной за счет того, что разные фреймы отличаются друг от друга не набором слотов и шпаций, а лишь информацией в них. Поэтому в системе «Эйдос» при увеличении числа фреймов само количество баз данных не увеличивается, а увеличивается лишь их размерность.

От нейросетевой модели представления знаний модель системы «Эйдос» отличается тем, что $[13,20]$ :

1) весовые коэффициенты на рецепторах не подбираются итерационным методом обратного распространения ошибки, а считаются прямым счетом на основе хорошо теоретически обоснованной модели, основанной на теории информации (это напоминает байесовские сети); 
2) весовые коэффициенты имеют хорошо теоретически обоснованную содержательную интерпретацию, основанную на теории информации;

3) нейросеть является нелокальной, как сейчас говорят «полносвязной».

\subsubsection{3d-интегральные когнитивные карты}

На рисунке 26 приведен фрагмент 3d-интегральной когнитивной карты, отражающая фрагмент около $27 \%$ СК-модели Inf1.

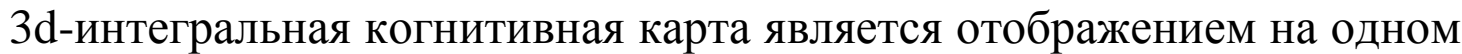
рисунке когнитивных диаграмм классов и значений факторов, отображенных соответственно на рисунках 16 и 20, и одного слоя нейронной сети, приведенного на рисунке 25.

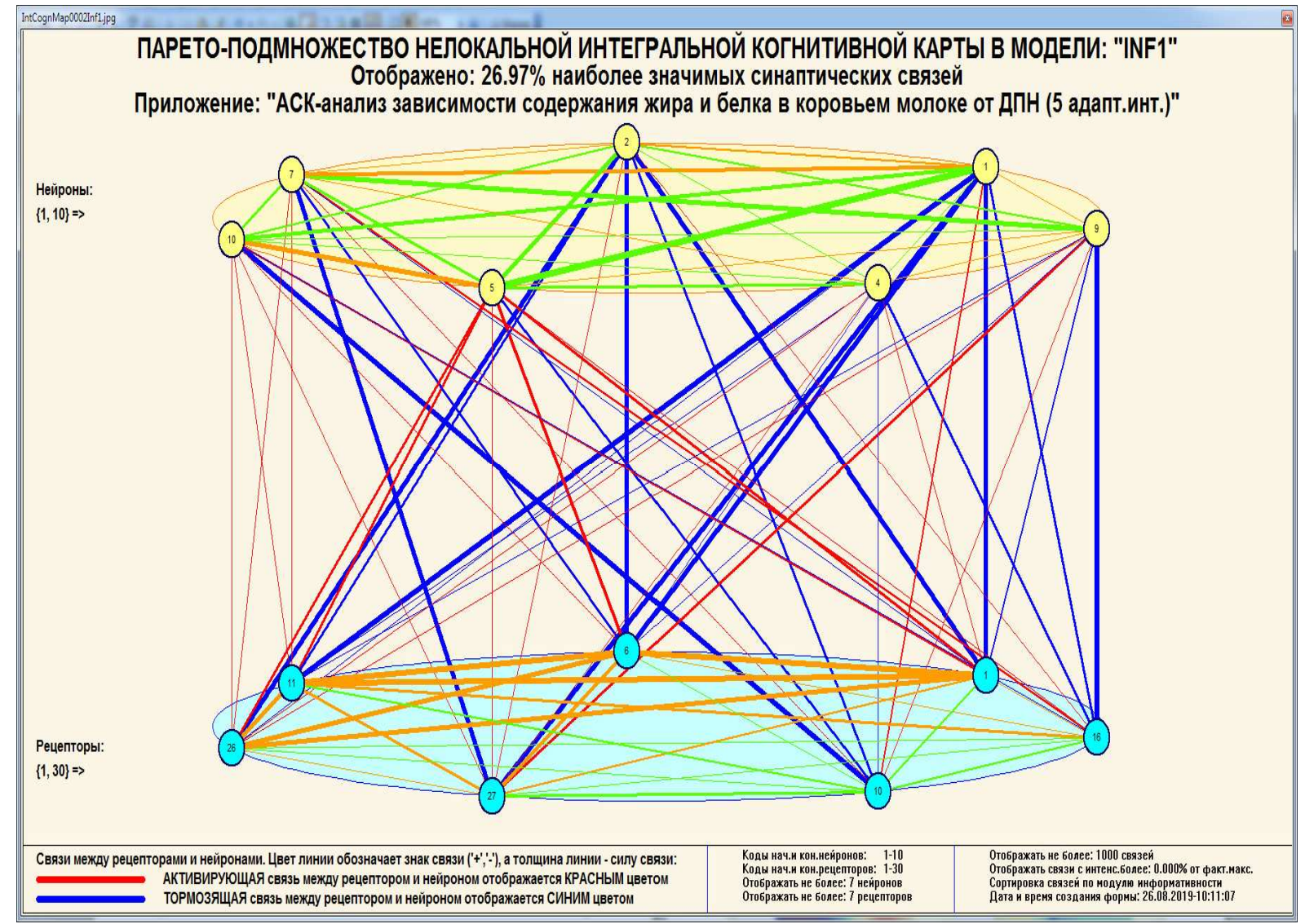

Рисунок 26. 3d-интегральная когнитивная карта в CK-модели Inf1

\subsection{7. Когнитивные фуунции}

Вместо описания того, что представляют собой когнитивные функции, приведем help соответствующего режима системы «Эйдос» (рисунок 27) и сошлемся на работу, в которой это довольно подробно описано [14]. 


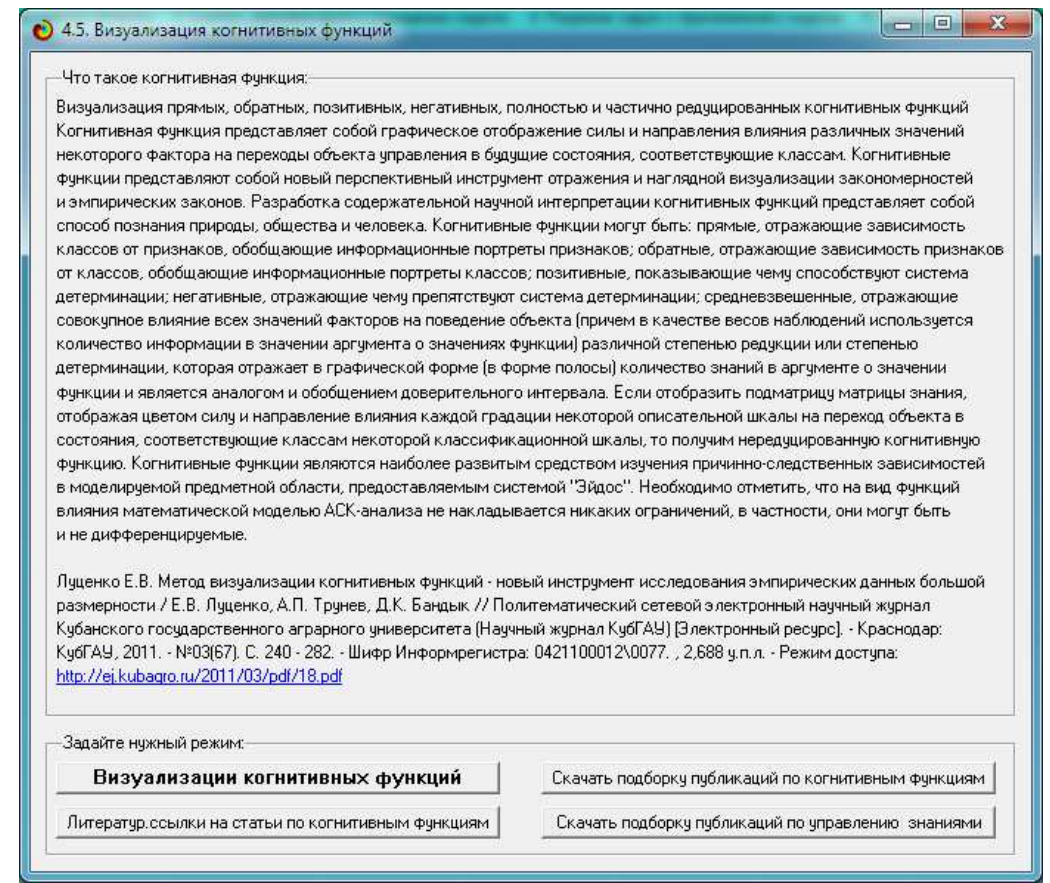

Рисунок 27. Help режима визуализации когнитивных функций

Когнитивная функция представляет собой графическое отображение силы и направления влияния различных значений некоторого фактора (признаков) на переходы объекта управления в будущие состояния, соответствующие классам. Классы являются градациями классификационных шкал.

Когнитивные функции представляют собой новый перспективный инструмент отражения и наглядной визуализации эмпирических закономерностей и эмпирических законов. Разработка содержательной научной интерпретации когнитивных функций представляет собой способ познания природы, общества и человека [17].

Когнитивные функции могут быть: прямые, отражающие зависимость классов от признаков, обобщающие информационные портреты признаков; обратные, отражающие зависимость признаков от классов, обобщающие информационные портреты классов; позитивные, показывающие чему способствуют система детерминации (обозначены белой линией); негативные, отражающие чему препятствуют система детерминации (обозначены черной линией); средневзвешенные, отражающие совокупное влияние всех значений факторов на поведение объекта (причем в качестве весов наблюдений используется количество информации в значении аргумента о значениях функции) различной степенью редукции или степенью детерминации, которая отражает в графической форме (в форме полосы разной толщины) количество знаний в аргументе о значении функции и является аналогом и обобщением доверительного интервала. 
Если отобразить подматрицу матрицы знания, отображая цветом силу и направление влияния каждой градации некоторой описательной шкалы на переход объекта в состояния, соответствующие классам некоторой классификационной шкалы, то получим нередуцированную когнитивную функцию.

Когнитивные функции являются наиболее развитым средством изучения причинно-следственных зависимостей в моделируемой предметной области, предоставляемым системой "Эйдос".

Необходимо отметить, что на вид функций влияния математической моделью АСК-анализа не накладывается никаких ограничений, в частности, они могут быть и не дифференцируемые [14].

На рисунках 28 приведены примеры некоторых когнитивных функций, наглядно отражающих силу и направление влияния значений (т.е. степени выраженности) различных параметров ДПН коровьего молока на такие важнейшие показатели его качества, как содержание в нем жира и белка.

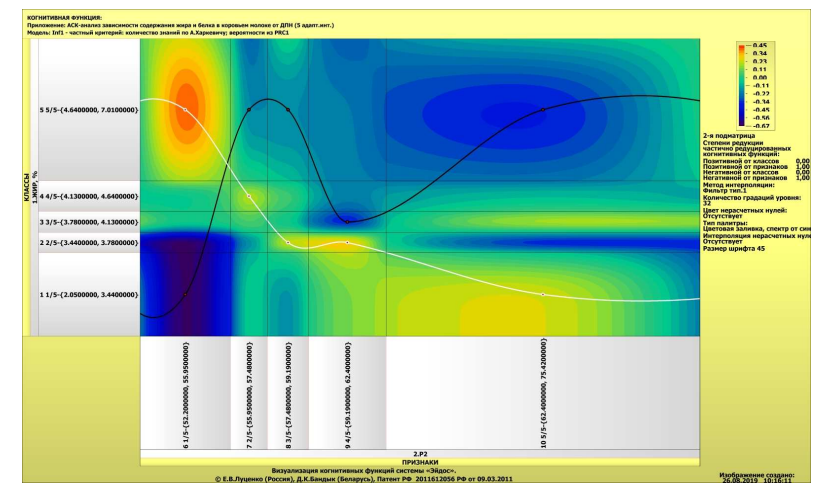

28-1

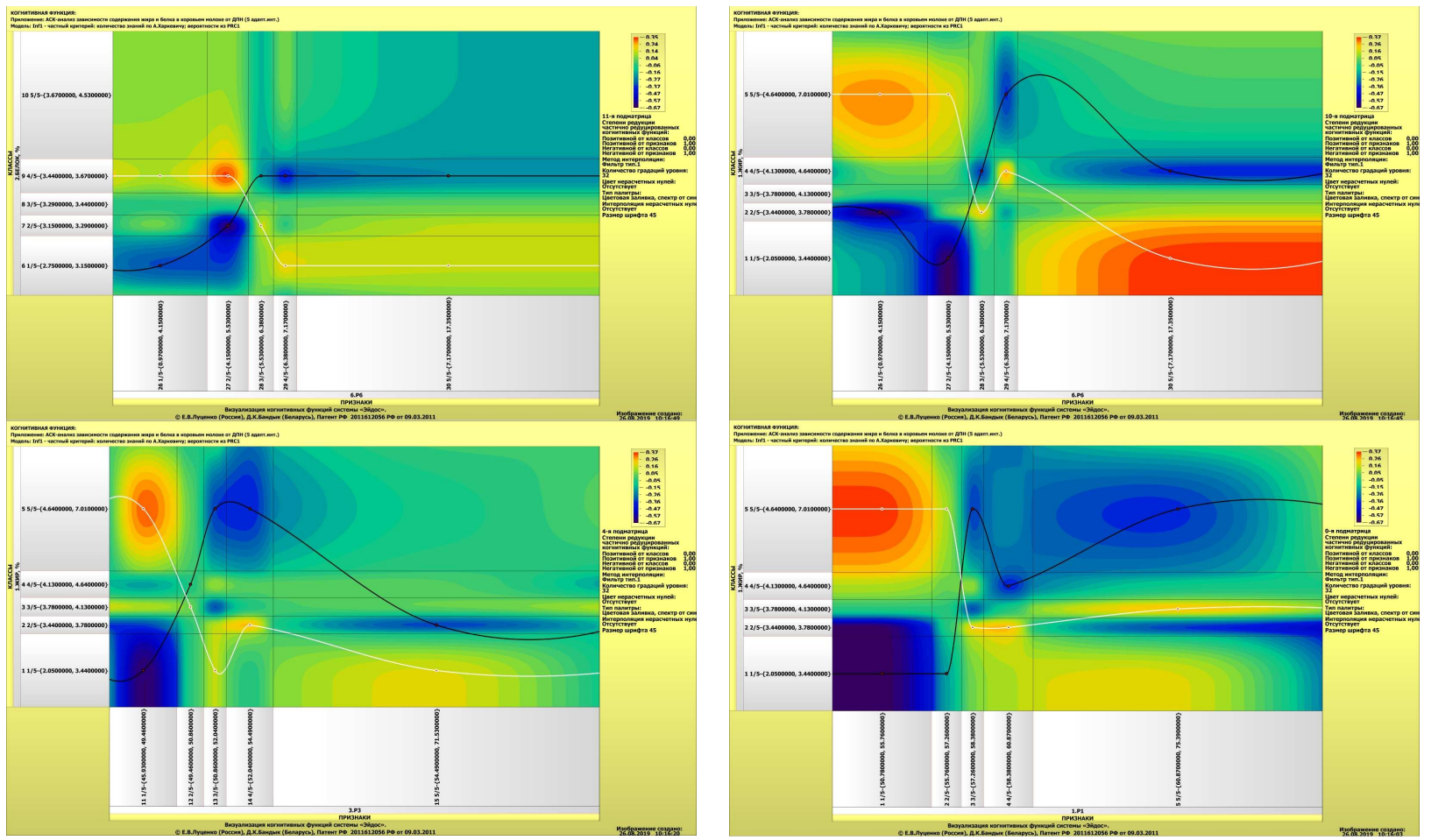

$28-2$ 


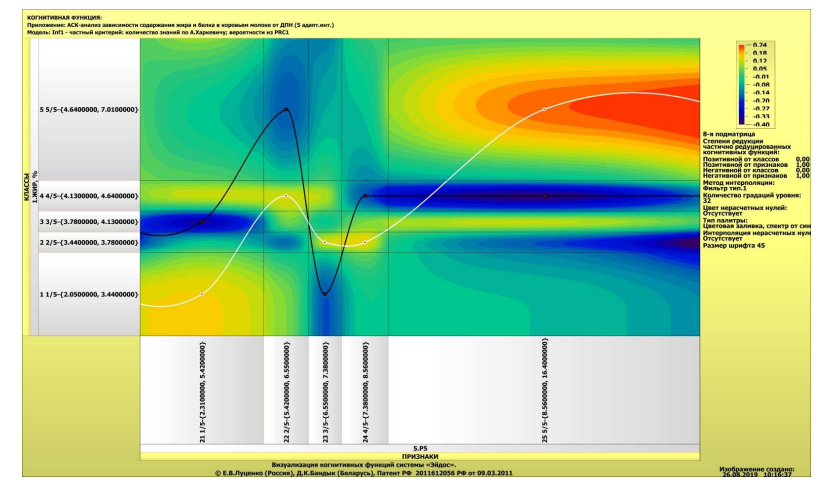

$28-3$

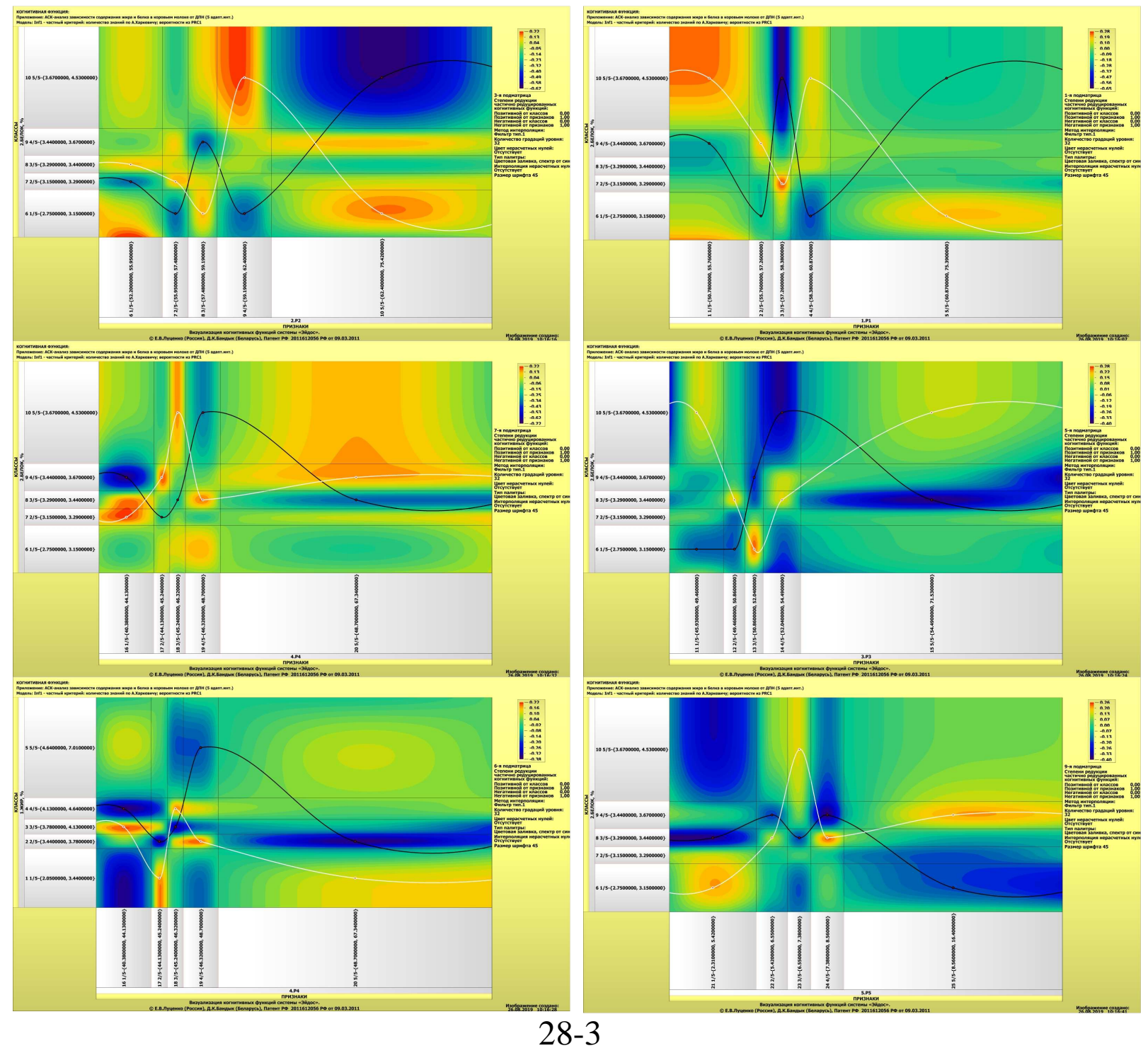

Рисунок 28. Примеры когнитивных функций в CК-модели INF1 с 5 адаптивными интервалами, отражающих силу и направление влияния значений параметров ДПН на качество коровьего молока: содержание в нем жира и белка ${ }^{3}$

\footnotetext{
${ }^{3}$ При увеличении масштаба просмотра когнитивные функции вполне читабельны
} 
Из когнитивных функций, приведенных на рисунке 28, хорошо видно, что зависимости между значениями параметров ДПН и показателями качества коровьего молока (содержание в нем жира и белков) в основном имеют довольно сложный характер.

Исключением является лишь когнитивные функции, приведенные на рисунках 28-1, из которых видно, что содержание жира в целом обратнопропорционально значению параметра Р2 ДПН, а белка - параметра Р6 ДПН. На рисунках 28-2 мы видим не так четко выраженную, можно сказать «почти обратно-пропорционально» зависимость. На рисунке 28-3 отображена «почти прямо-пропорциональная» зависимость содержания жира в коровьем молоке от значений параметра Р5 ДПН. На рисунках 28-4 зависимости имеют более сложный вид, чем прямо или обратно пропорциональные.

Поэтому и возникает сомнение в том, что корреляционнорегрессионный анализ является вполне адекватным методом для формально-математического отображения взаимосвязей между значениями параметров ДПН и содержанием жира и белка в коровьем молоке. По этой же причине по мнению авторов для этой цели возможно больше подходят методы искусственного интеллекта. Пример применения для этой цели одного из таких методов: АСК-анализа и его программного инструментария - интеллектуальной системы «Эйдос» подробно рассматривается в данной работе. Возникает гипотеза о том, что на наблюдаемый характер зависимостей могло повлиять малое соотношение сигнал/шум в экспериментальных измерительных пробах, приведенных в таблице 3., т.е. проще говоря высокий уровень шума в них, что и создает проблемы для выделения полезного сигнала из этих данных. Предлагается идея, как улучшить отношение сигнал/шум, основанная на фундаментальном свойстве шума состоящем в том, что в среднем шум равен нулю и при увеличении числа наблюдений полезный сигнал суммируется, а шум уменьшается, что и позволяет улучшить отношение сигнал/шум. В нашем случае это означает, что нужно увеличить объем выборки исходных экспериментальных данных, представленных в таблице 3. Однако, этот способ нам недоступен. Но есть и другой вариант: увеличить размеры интервалов усреднения, который мы и используем.

В исследуемой СК-модели INF1 с 5 адаптивными интервалами на один интервал приходится 22-23 наблюдения (рисунок 29). Построим СКмодель с 3 адаптивными интервалами (рисунок 30). В этой модели мы получаем 37-38 наблюдений на адаптивный интервал. Когнитивные функции в этой модели приведены на рисунках 31. Правильность гипотезы и идеи ее проверки подтвержждается тем, что среди когнитивных функций, приведенных на рисунках 31 , гораздо большая доля относиться к прямо и обратно пропорциональным функциям, чем при 5 интервалах. 


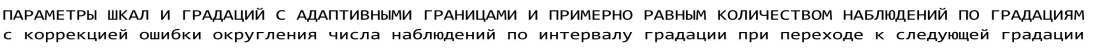

КЛАССИФИКАЦИОННАЯ ШКАЛА: КОД: [ 1], наим.:" Жир, \%", набл.на шкалу (всего): 112, тип/число градаций в шкале: "Равное число событий в интервалах"/5

1 Наим. градации: $1 / 5-\{2.0500000,3.4400000\}$, размер интервала=1.3900000, расч./факт.число наблюдений на градацию: $22 / 22$

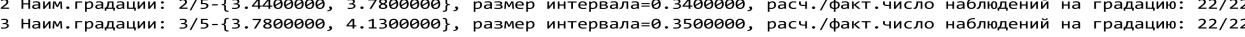

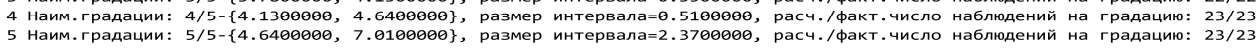

КЛАССИФИКАЦИОННАЯ ШКАЛА: КОД: [ 2], наим.:" БЕЛоК, \%", набл. на шкалу (всего): 112, тип/число градаций в шкале: "Равное число событий в интервалах"/5

6 Наим.градации: $1 / 5-\{2.7500000,3.1500000\}$, размер интервала=0.4000000, расч./Факт.Число наблюдений на градацию: $22 / 22$

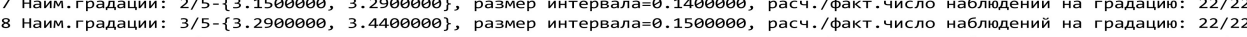

9 Наим.градации: 4/5-\{3.4400000, 3.6700000\}, размер интервала=0.2300000, расч./факт.число наблюдений на градацию: $23 / 23$
10 Наим. градации: 5/5-\{3.6700000, 4.5300000\}, размер интервала=0.8600000, расч./факт.число наблюдений на градацию: 23/23

ОПИСАТЕЛЬНАЯ ШКАЛА:КОД: [ 1], наим.: "Р1", набл.на шкалу (всего):112, тип/число градаций в шкале: "Равное число событий в интервалах"/5 1 Наим. градации: 1/5-\{50.7800000, 55.7600000\}, размер интервала= 4.9800000, расч./факт. число наблюдений на градацию: $22 / 22$ 2 Наим.градации: 2/5-\{55.7600000, 57.2600000\}, размер интервала $=1.5000000$, расч./факт.число наблюдений на градацию: 22/22 3 Наим. градации: 3/5-\{57.2600000, 58.3800000\}, размер интервала- 1.1200000, расч./факт.число наблюдений на градацию: $22 / 22$ 5 Наим.градации: 5/5-\{60.8700000, 75.3900000\}, размер интервала=14.5200000, расч./факт.число наблюдений на градацию: 23/23

ОПИСАТЕЛЬНАЯ ШКАЛА:КОД: [ 2], наим.: "Р2", набл.на шкалу (всего):112, тип/число градаций в шкале: "Равное число событий в интервалах"/5 6 Наим. градации: 1/5-\{52.2000000, 55.9500000\}, размер интервала= 3.7500000, расч./факт. число наблюдений на градацию: $22 / 22$ 7 Наим.градации: 2/5-\{55.9500000, 57.4800000\}, размер интервала $=1.5300000$, расч. факт.число наблюдений на градацию: $22 / 22$ 8 Наим.градации: 3/5-\{57.4800000, 59.1900000\}, размер интервала= 1.7100000 , расч./факт. число наблюдений на градацию: $22 / 22$ 10 наим.градации: 5/5-\{62.4000000, 75.4200000\}, размер интервала=13.0200000, рас4./факт.число наблюдений на градацию: 23/23

ОПИСАТЕЛЬНАЯ ШКАЛА:КОД: [ 3], наим.: "РЗ", набл.на шкалу (всего):112, тип/число градаций в шкале: "Равное число событий в интервалах"/5 11 Наим.градации: 1/5-\{45.9300000, 49.4600000\}, размер интервала= 3.5300000, расч./факт.число наблюдений на градацию: 22/22 12 Наим.градации: $2 / 5-\{49.4600000,50.8600000\}$, размер интервала= 1.4000000 , расч./факт.Число наблюдений на градацию: $22 / 22$

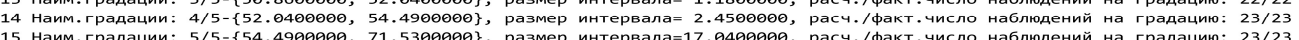

ОПИСАТЕЛЬНАЯ ШКАЛА:КОД: [ 4], наим.: "Р4", набл.на шкалу (всего):112, тип/число градаций в шкале: "Равное число событий в интервалах"/5 16 Наим.градации: $1 / 5-\{40.3800000,44.1300000\}$, размер интервала $=3.7500000$, расч./факт. число наблюдений на градацию: $22 / 22$ 17 Наим. градации: $2 / 5-\{44.1300000,45.2400000\}$, размер интервала= 1.1100000 , расч./факт.число наблюдений на градацию: $22 / 22$

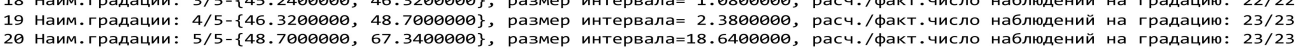

ОПИСАТЕЛЬНАЯ ШКАЛА:КОД: [ 5], наим.: "Р5", набл.на шкалу (всего):112, тип/число градаций в шкале: "Равное число событий в интервалах"/5

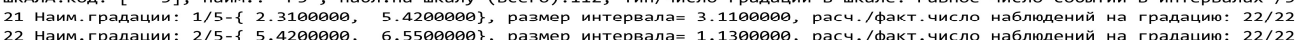
23 Наим.градации: $2 / 5$. $5.4200000,6.5500000\}$, размер интервала $=1.1300000$, расч./факт. число наблюдений на градацию: $22 / 22$

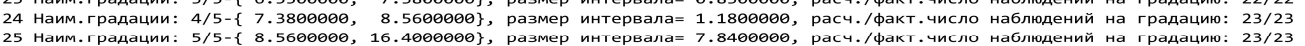

ОПИСАТЕЛЬНАЯ ШКАЛА:Код: [ 6], Наим.: "Рб", набл.на шкалу (всего):112, тип/число градаций в шкале: "Равное число событий в интервалах"/5

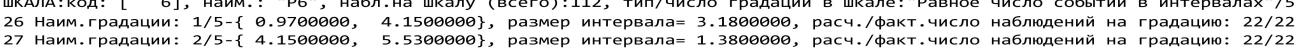
28 наим. градации: 3/5-\{5.5300000, 6.3800000\}, размер интервала= 0.8500000 , расч./факт.число наблюдений на градацию: $22 / 22$

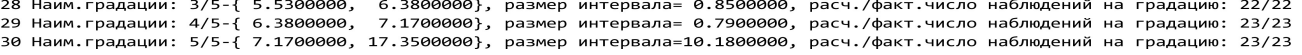

Рисунок 29. Классификационные и описательные шкалы при 5 адаптивных интервалах

ПАРАМЕТРЫ ШКАЛ И ГРАДАЦИЙ С АДАПТИВНЫМИ ГРАНИЦАМИ И ПРИМЕРНО РАВНЫМ КОЛИЧЕСТВОМ НАБЛЮДЕНИЙ ПО ГРАДАЦИЯМ

с коррекцией ошибки округления числа наблюдений по интервалу градации при переходе к следующей градации

КЛАССИфИКАЦИОННАЯ ШКАЛА: код: [ 1], наим.: " ЖИР, \%", набл.на шкалу (всего): 112, тип/число градаций в шкале: "Равное число событий в интервалах"/з 1 Наим.градации: $1 / 3-\{2.0500000,3.6900000\}$, размер интервала=1.6400000, расч./факт.число наблюдений на градацию: $37 / 37$

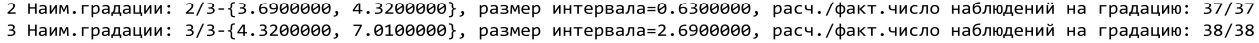

КЛАССИФИКАЦИОННАЯ ШКАЛА: КоД: [ 2], наим.:" БЕЛоК, \%", набл.на шкалу (всего): 112, тип/число градаций в шкале: "Равное число событий в интервалах"/3 4 Наим. градации: $1 / 3-\{2.7500000,3.2500000\}$, размер интервала= 0.5000000 , расч./факт. число наблюдений на градацию: $37 / 37$

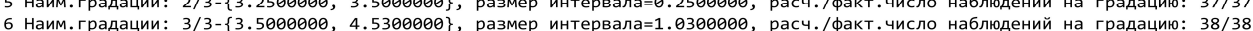

ОПИСАТЕЛЬНАЯ ШКАЛА:Код: [ 11, наим.: "Р1", набл.на шкалу (всего):112, тип/число градаций в шкале:"Равное число событий в интервалах"/3 1 Наим.градации: $1 / 3-\{50.7800000,56.8500000\}$, размер интервала= 6.0700000 , расч./факт.число наблюдений на градацию: $37 / 37$ 2 наим.градации: $2 / 3-\{56.8500000,58.9900000\}$, размер интервала= 2.1400000 , расч./факт. число наблюдений на градацию: $37 / 37$
3 Наим. градации: $3 / 3-\{58.9900000,75.3900000\}$, размер интервала $=16.4000000$, расч./факт.число наблюдений на градацию: $38 / 38$

ОПИСАТЕЛЬНАЯ ШКАЛА:Код: [ 2], наим.: "Р2", набл.на шкалу (всего):112, тип/число градаций в шкале:"Равное число событий в интервалах"/3 4 Наим.градации: $1 / 3-\{52.2000000,57.0900000\}$, размер интервала $=4.8900000$, расч./факт. число наблюдений на градацию: $37 / 37$ 5 Наим.градации: 2/3-\{57.0900000, 59.8600000\}, размер интервала= 2.7700000 , расч./Факт.число наблюдений на градацию: $37 / 37$
6 Наим.градации: $3 / 3-\{59.8600000,75.4200000\}$, размер интервала $=15.5600000$, расч./факт.число наблюдений на градацию: $38 / 38$

ОПИСАТЕЛЬНАЯ ШКАЛА:Код: [ 3], наим.: "РЗ", набл.на шкалу (всего):112, тип/число градаций в шкале:"Равное число событий в интервалах"/3

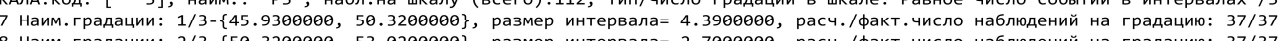
8 Наим.градации: 2/3-\{50.3200000, 53.0200000\}, размер интервала $=2.7000000$, расч./факт. число наблюдений на градацию: $37 / 37$
9 Наим.градации: 3/3-\{53.0200000, 71.5300000$\}$, размер интервала $=18.5100000$, расч./факт. иисло наблюдений на градацию: 38/38

ОПИСАТЕЛЬНАЯ ШКАЛА:Код: [ 4], наим.: "Р4", набл.на шкалу (всего):112, тип/число градаций в шкале:"Равное число событий в интервалах"/3 10 Наим. градации: $1 / 3-\{40.3800000,44.9000000\}$, размер интервала= 4.5200000, расч./факт. число наблюдений на градацию: $37 / 37$ 12 Наим. градации: $3 / 3-\{46.8500000,67.3400000\}$, размер интервала=20.4900000, расч./факт. число наблюдений на градацию: $38 / 38$

ОПИСАТЕЛЬНАЯ ШКАЛА:Код: [ 5], наим.: "Р5", набл.на шкалу (всего):112, тип/число градаций в шкале: "Равное число событий в интервалах"/3 13 Наим.градации: $1 / 3-\{2.3100000,6.2200000\}$, размер интервала= 3.9100000, расч./факт.число наблюдений на градацию: 37/37 14 Наим.градации: 2/3-\{6.2200000, 8.0000000\}, размер интервала= 1.7800000 , расч./факт. число наблюдений на градацию: $37 / 37$ 15 Наим. градации: З/3-\{ 8.0000000,

ОПИСАТЕЛЬНАЯ ШКАЛА:код: [ 6], наим.: "Р6", набл.на шкалу (всего):112, тип/число градаций в шкале: "Равное число событий в интервалах"/3 16 Наим.градации: $1 / 3-\{0.9700000,5.1500000\}$, размер интервала $=4.1800000$, расч./факт.число наблюдений на градацию: $37 / 37$
17 Наим.градации: $2 / 3-\{5.1500000,6.7100000\}$, размер интервала= 1.5600000, расч./факт.число наблюдений на градацию: $37 / 37$ 18 Наим.градации: $3 / 3-\{6.7100000,17.3500000\}$, размер интервала=10.6400000, расч./факт. число наблюдений на градацию: $38 / 38$

Рисунок 30. Классификационные и описательные шкалы при 3 адаптивных интервалах 


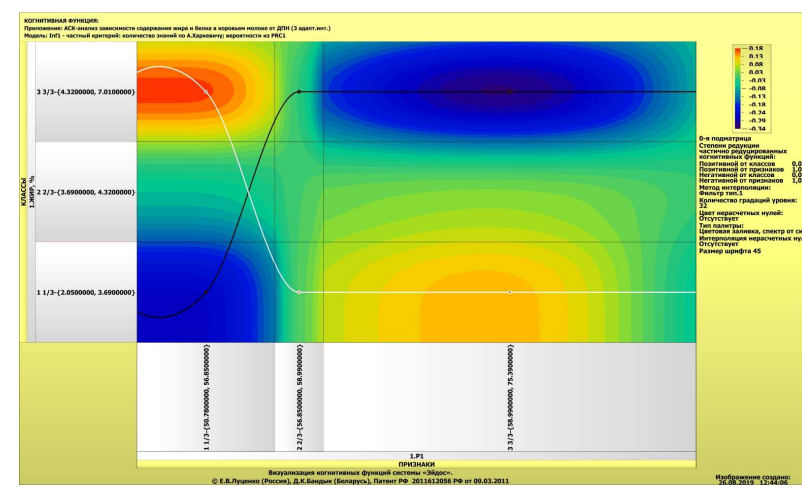

a

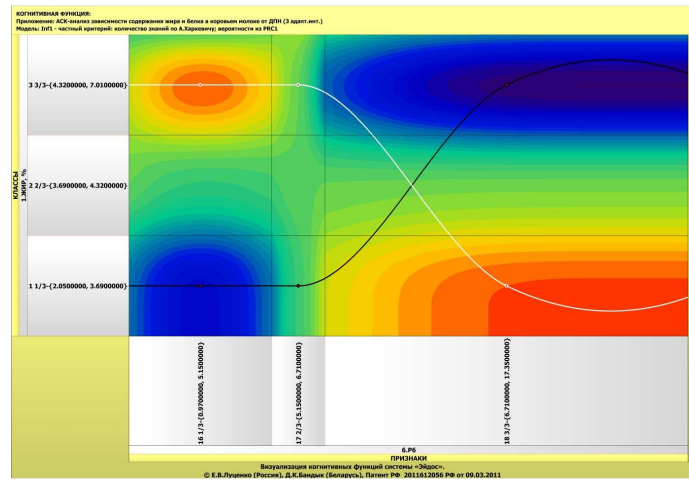

B

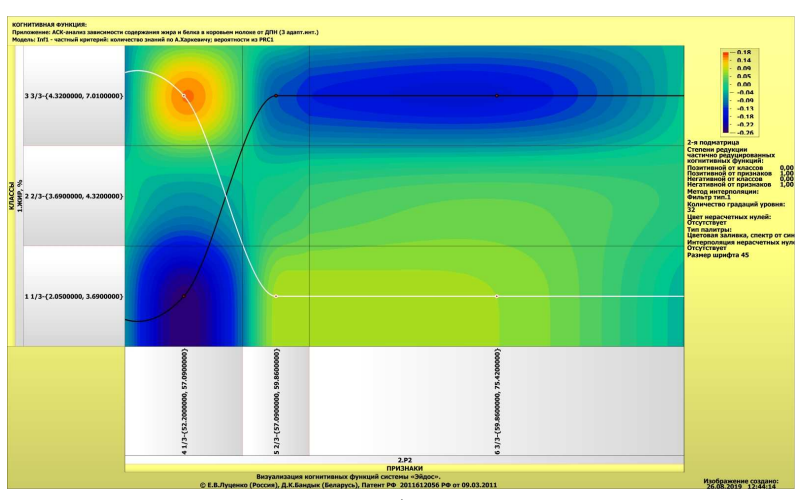

6
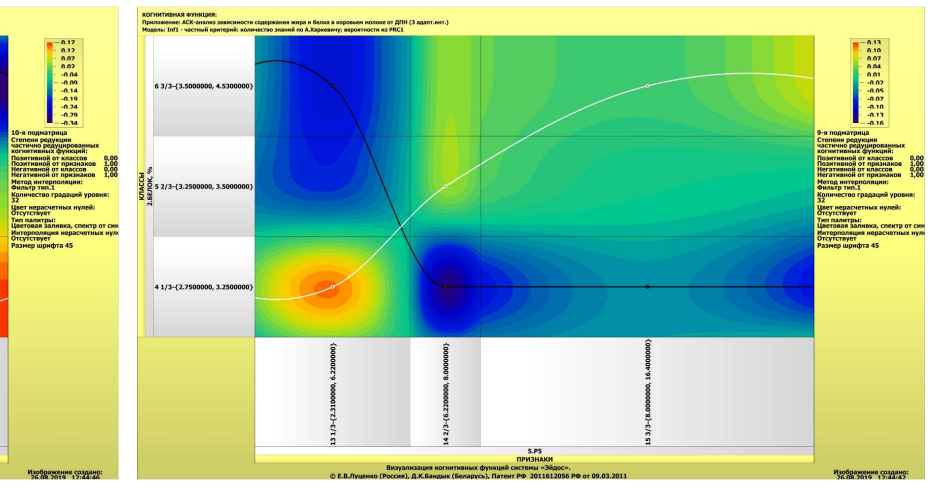

$\Gamma$

\section{1-1}

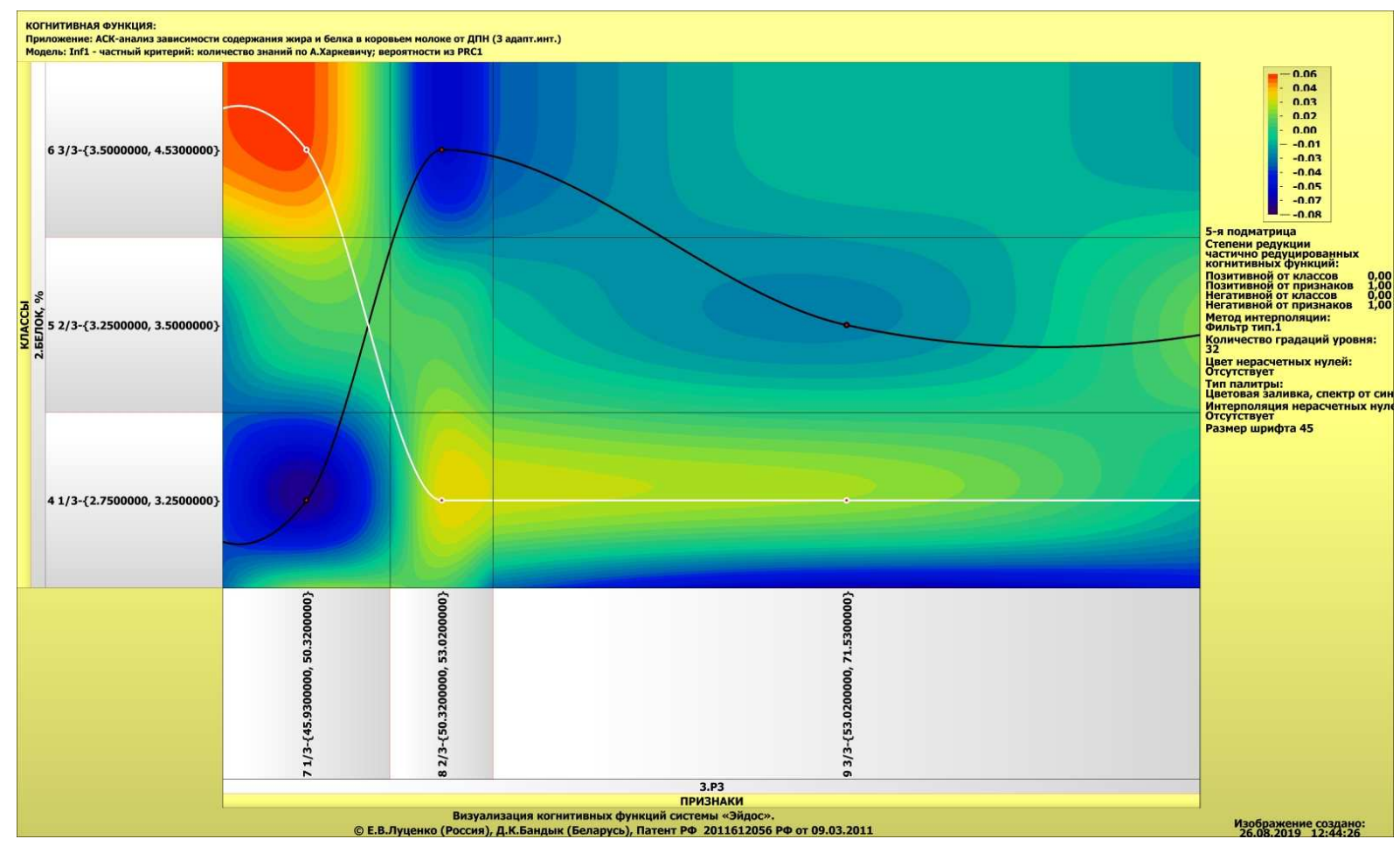

$31-2$ 

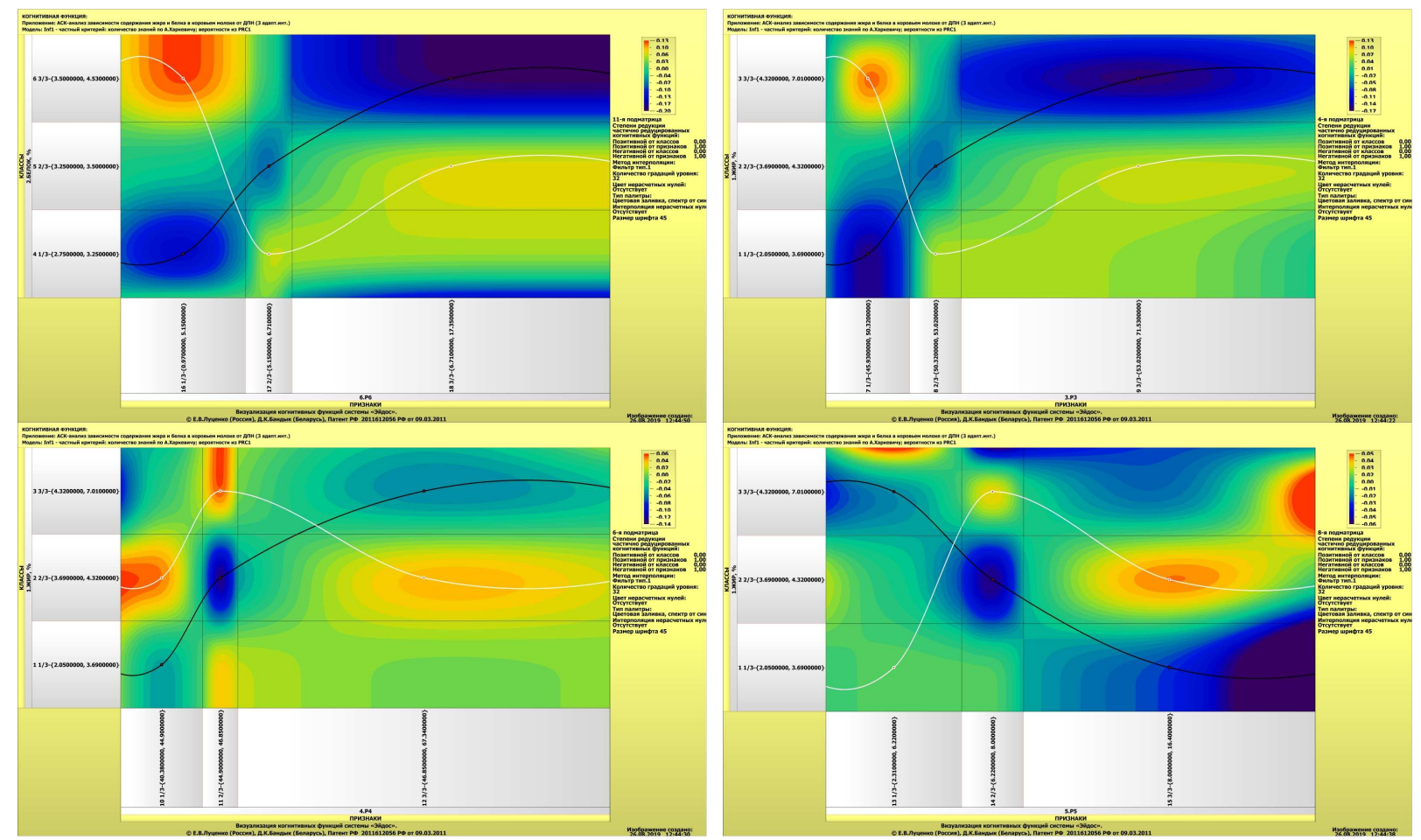

$31-3$
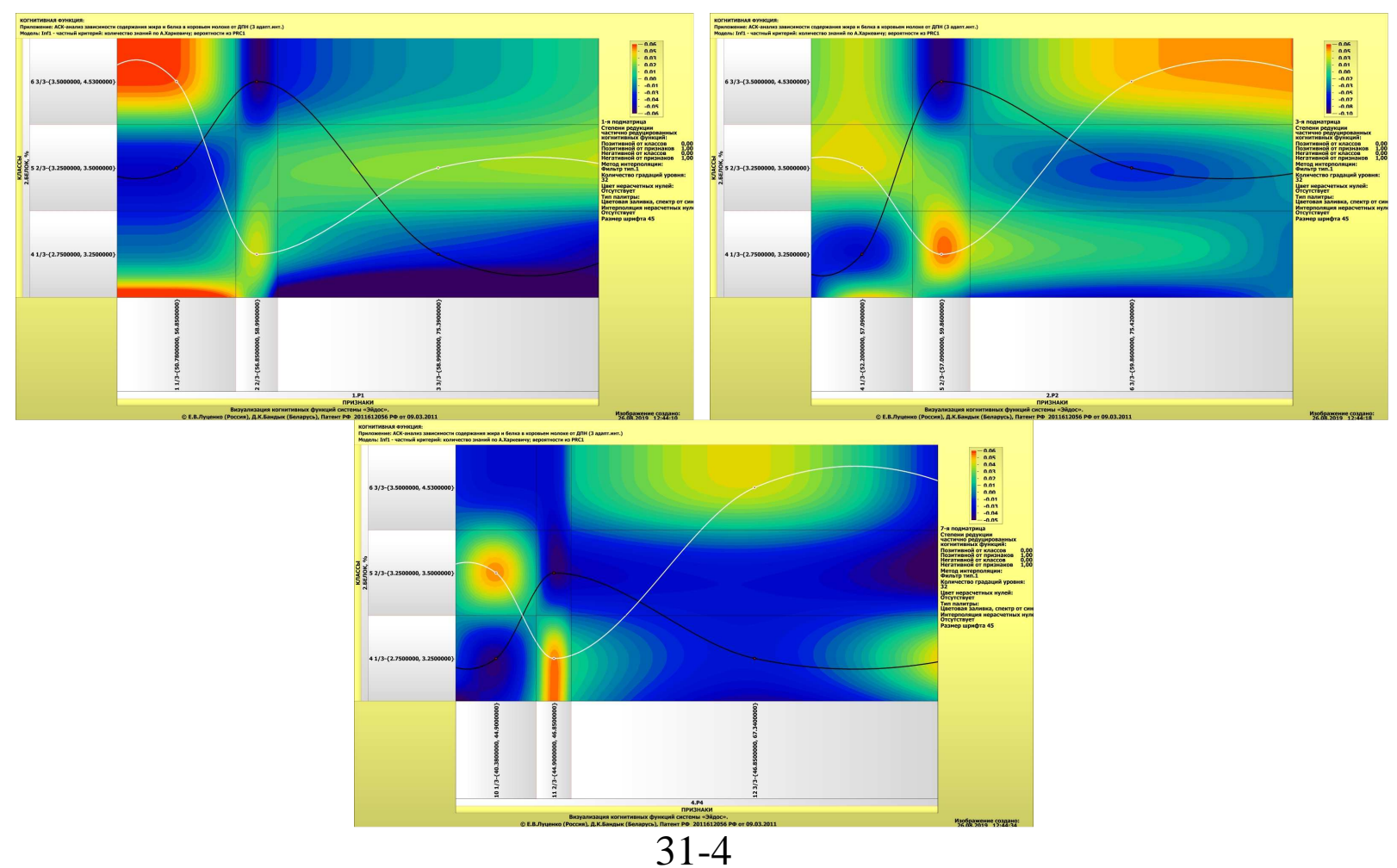

Рисунок 31. Примеры когнитивных функций в CK-модели INF1 с 5 адаптивными интервалами, отражающих силу и направление влияния значений параметров ДПН на качество коровьего молока: содержание в нем жира и белков ${ }^{4}$

\footnotetext{
${ }^{4}$ При увеличении масштаба просмотра когнитивные функции вполне читабельны
} 
На рисунках 31-1 приведены 4 когнитивных функции, в которых наблюдаются монотонные зависимости прогнозируемого и непрогнозируемого содержания жира и белка от значений параметров Р1, P2, Р5 и Р6 ДПН:

- прогнозируемое содержание жира обратно-пропорционально значениям параметров Р1, P2 и Р6 (белая линия, соединяющая точки с максимальным количеством информации);

- прогнозируемое содержание белка прямо-пропорционально значениям параметра Р5(белая линия, соединяющая точки с максимальным количеством информации);

- непрогнозируемое содержание жира прямо-пропорционально значениям параметров Р1, Р2 и Р6 (черная линия, соединяющая точки с минимальным количеством информации);

- непрогнозируемое содержание белка обратно-пропорционально значениям параметра P5 (черная линия, соединяющая точки с минимальным количеством информации).

Для этих когнитивных функций прогнозируемые и непрогнозируемые содержание жира и белка находятся в полном взаимном соответствии, т.е. противоположны друг другу по смыслу. В СК-моделях с 5 интервалами такого соответствия в строгом виде вообще не наблюдается (оно есть лишь приблизительно).

На рисунках 31-2 приведена 1 когнитивная функция, в которой прогнозируется обратно-пропорциональная зависимость содержания белка в коровьем молоке от значений параметра Р6 ДПН а не прогнозируемое содержание белка имеет сложный характер..

На рисунках 31-3 приведено 4 когнитивных функций, в которых не прогнозируются монотонные зависимости содержания белка и жира в коровьем молоке значений параметров ДПН, а прогнозируемые зависимости имеют сложный характер:

- непрогнозируемое содержание белка прямо-пропорционально значениям параметра P6 (черная линия, соединяющая точки с минимальным количеством информации);

- непрогнозируемое содержание жира прямо-пропорционально значениям параметров P3 и Р4 (черная линия, соединяющая точки с минимальным количеством информации);

- непрогнозируемое содержание жира обратно-пропорционально значениям параметра P5 (черная линия, соединяющая точки с минимальным количеством информации).

На рисунках 31-4 приведены 3 когнитивные функции, в которых и прогнозируемые, и не прогнозируемые зависимости содержания белка и жира в коровьем молоке значений параметров ДПН имеют сложный немонотонный характер: это зависимости содержания белка от значений параметров Р1, Р2 и Р4 ДПН. 


\subsection{8. Сила и направление влияния значений параметров ДПН и сила влияния самих параметров ДПН на содержание жира и белка в коровьем молоке}

На рисунках 5, 6, 7 приведены фрагменты некоторых статистических и системно-когнитивных моделей, отражающих моделируемую предметную область.

Строки матриц моделей соответствуют значениям факторов, т.е. значениям параметров ДПН (градации описательных шкал).

Колонки матриц моделей соответствуют различным классам, отражающим различное содержание жира и белка в коровьем молоке (градации классификационных шкал).

Числовые значения в ячейках матриц моделей, находящихся на пересечении строк и колонок, отражают направление (знак) и силу влияния конкретного значения параметра ДПН, соответствующего сроке, на конкретное значение показателя качества молока, соответствующего колонке.

Если какое-то значение параметра ДПН слабо влияет на качество молока, то в соответствующей строке матрицы модели будут малые по модулю значения разных знаков, если же влияние сильное - то и значения будут большие по модулю разных знаков.

Если значение показателя ДПН способствует получению некоторого определенного показателя качества молока, то в соответствующей этому результату ячейке матрицы модели будут положительные значения, если же понижает - то и значения будут отрицательные.

Из этого следует, что суммарную силу влияния того или иного значения параметра ДПН на показатели качества молока (т.е. ценность данного значения параметра ДПН для решении задачи квалиметрии и других задач) можно количественно оценивать степенью вариабельности значений в строке матрицы модели, соответствующей этому значению параметра ДПН.

Существует много мер вариабельности значений: это и среднее модулей отклонения от среднего, и дисперсия, и среднеквадратичное отклонение и другие. В АСК-анализе и системе «Эйдос» для этой цели принято использовать среднеквадратичное отклонение. Численно оно равно стандартному отклонению и вычисляется по той же формуле, но мы предпочитаем не использовать термин «стандартное отклонение», т.к. он предполагает нормальность распределения исследуемых последовательностей чисел, а значит и проверку соответствующих статистических гипотез.

Самая правая колонка в матрицах моделей на рисунках $5,6,7$ содержит количественную оценку вариабельности значений строки модели (среднеквадратичное отклонение), которая и представляет собой ценность 
значения параметра ДПН, соответствующего строке, для решения задачи квалиметрии и других задач, рассмотренных в работе.

Если рассортировать матрицу модели по этой самой правой колонке в порядке убывания, а потом просуммировать значения в ней нарастающим итогом, то получим логистическую Парето-кривую, отражающую зависимость ценности модели от числа наиболее ценных признаков в ней (рисунок 32, таблица 7).

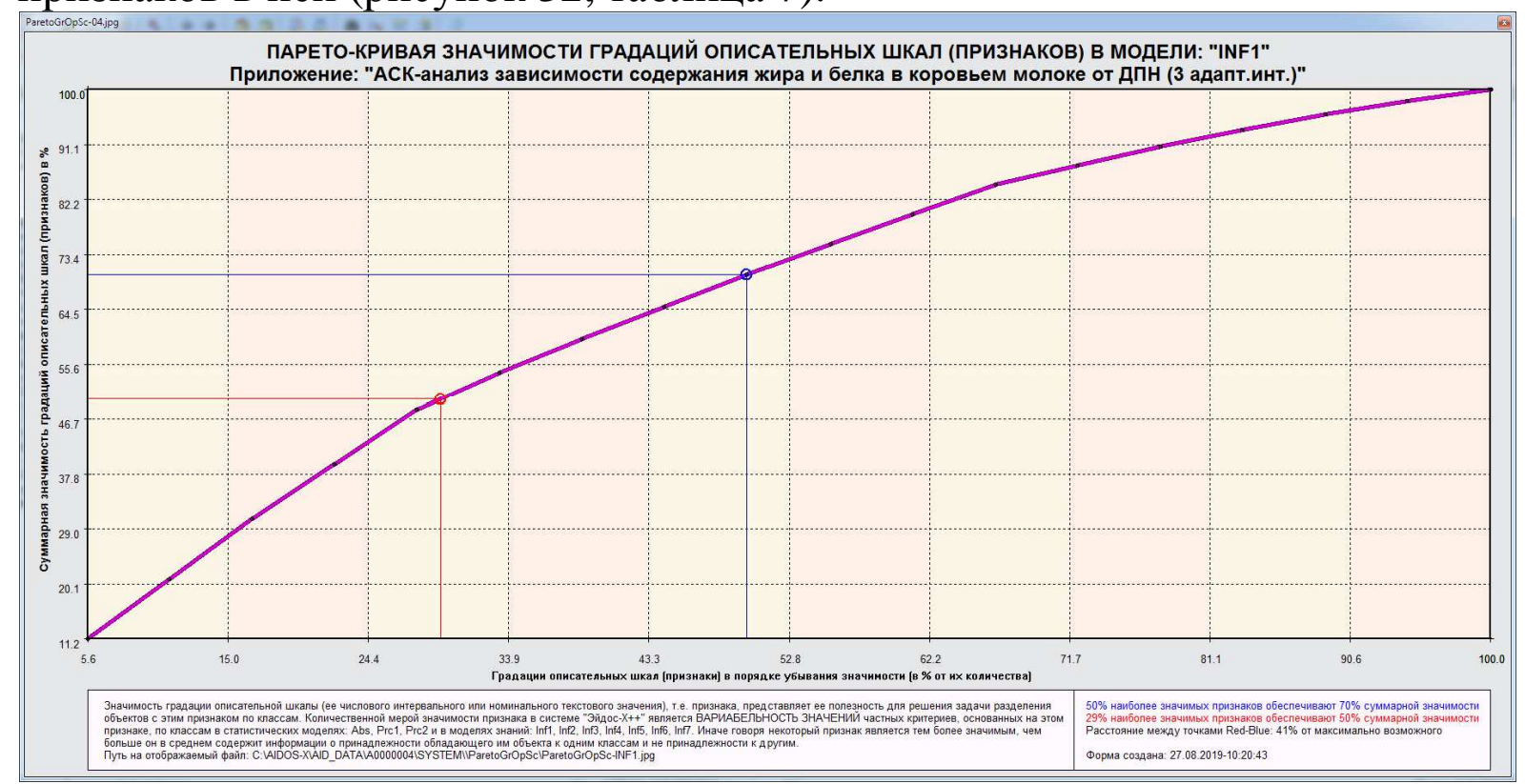

Рисунок 32. Парето-кривая значимости градаций описательных шкал

Таблица 7 - Парето-таблица значимости градаций описательных шкал, т.е. сила влияния значений параметров ДПН на качество молока в CK-модели INF1 с 3 адаптивными градациями

\begin{tabular}{|c|c|c|c|c|c|}
\hline № & $\begin{array}{c}\text { Код } \\
\text { значения } \\
\text { параметра } \\
\text { ДПН }\end{array}$ & Наименование параметра ДПН & $\begin{array}{c}\text { Код } \\
\text { параметра } \\
\text { ДПН }\end{array}$ & $\begin{array}{c}\text { Ценность } \\
\text { значения } \\
\text { параметра } \\
\text { ДПН (\%) }\end{array}$ & $\begin{array}{c}\text { Ценность } \\
\text { значения } \\
\text { параметра } \\
\text { ДПН } \\
\text { нарастающим } \\
\text { итогом (\%) }\end{array}$ \\
\hline 1 & 18 & P6-3/3-\{6.7100000, 17.3500000\} & 6 & 11,210 & 11,210 \\
\hline 2 & 16 & P6-1/3-\{0.9700000, 5.1500000\} & 6 & 9,737 & 20,947 \\
\hline 3 & 3 & $\mathrm{P} 1-3 / 3-\{58.9900000,75.3900000\}$ & 1 & 9,676 & 30,624 \\
\hline 4 & 4 & P2-1/3-\{52.2000000, 57.0900000\} & 2 & 8,874 & 39,498 \\
\hline 5 & 1 & $\mathrm{P} 1-1 / 3-\{50.7800000,56.8500000\}$ & 1 & 8,755 & 48,253 \\
\hline 6 & 7 & P3-1/3- $\{45.9300000,50.3200000\}$ & 3 & 6,068 & 54,321 \\
\hline 7 & 6 & P2-3/3-\{59.8600000, 75.4200000\} & 2 & 5,461 & 59,782 \\
\hline 8 & 9 & P3-3/3-\{53.0200000, 71.5300000\} & 3 & 5,199 & 64,981 \\
\hline 9 & 14 & P5-2/3- $\{6.2200000,8.0000000\}$ & 5 & 5,189 & 70,170 \\
\hline 10 & 5 & P2-2/3-\{57.0900000, 59.8600000\} & 2 & 4,973 & 75,143 \\
\hline 11 & 13 & P5-1/3-\{2.3100000, 6.2200000\} & 5 & 4,811 & 79,954 \\
\hline 12 & 11 & P4-2/3- $\{44.9000000,46.8500000\}$ & 4 & 4,752 & 84,706 \\
\hline 13 & 8 & P3-2/3- $\{50.3200000,53.0200000\}$ & 3 & 3,080 & 87,786 \\
\hline 14 & 10 & $\mathrm{P} 4-1 / 3-\{40.3800000,44.9000000\}$ & 4 & 3,004 & 90,791 \\
\hline 15 & 17 & P6-2/3- $\{5.1500000,6.7100000\}$ & 6 & 2,781 & 93,572 \\
\hline 16 & 12 & P4-3/3-\{46.8500000, 67.3400000\} & 4 & 2,550 & 96,122 \\
\hline 17 & 2 & $\mathrm{P} 1-2 / 3-\{56.8500000,58.9900000\}$ & 1 & 2,035 & 98,157 \\
\hline 18 & 15 & P5-3/3-\{8.0000000, 16.4000000\} & 5 & 1,843 & 100,000 \\
\hline
\end{tabular}


Из рисунка 32 и таблицы 7 видно, что 50\% наиболее ценных для решения задачи квалиметрии молока значений ДПН обуславливают $70 \%$ суммарной ценности, а 50\% суммарной ценности обеспечиваются $29 \%$ наиболее ценных значений ДПН.

Обращает на себя внимание, что наиболее ценным является высокое значение параметра Р6 ДПН, а наименее ценным - высокое значение параметра Р5 ДПН, причем наиболее ценное значение параметра ДПН в 6 раз выше, чем наименее ценное.

Из таблицы 7 видно, что наиболее сильное влияние на показатели качества молока оказывают значения параметров Р6 и Р1 ДПН:

- P6-3/3- $\{6.7100000,17.3500000\}$;

- P6-1/3- $\{0.9700000,5.1500000\}$;

$-\mathrm{P} 1-3 / 3-\{58.9900000,75.3900000\}$;

$-\mathrm{P} 2-1 / 3-\{52.2000000,57.0900000\}$;

- P1-1/3-\{50.7800000, 56.8500000\};

а наиболее низкое - значения параметров Р4 и Р5:

- P4-1/3-\{40.3800000, 44.9000000\};

$-\mathrm{P} 6-2 / 3-\{5.1500000,6.7100000\}$;

$-\mathrm{P} 4-3 / 3-\{46.8500000,67.3400000\}$;

$-\mathrm{P} 1-2 / 3-\{56.8500000,58.9900000\}$;

- P5-3/3- $8.0000000,16.4000000\}$.

Ценность же параметра ДПН (всей описательной шкалы или фактора), для решения этих задач можно количественно оценивать как среднее от ценности значений этого параметра (таблица 8).

Таблица 8 - Парето-таблица значимости описательных шкал,

т.е. сила влияния параметров ДПН на качество молока в CК-модели INF1 с 3 адаптивными градациями

\begin{tabular}{|c|c|c|c|c|}
\hline № & $\begin{array}{c}\text { Код } \\
\text { паметра } \\
\text { ДПН }\end{array}$ & $\begin{array}{c}\text { Наименование } \\
\text { параметра } \\
\text { ДПН }\end{array}$ & $\begin{array}{c}\text { Ценность } \\
\text { Ценность } \\
\text { параметра } \\
\text { ДПН (\%) }\end{array}$ & $\begin{array}{c}\text { ДПН } \\
\text { нарастающим } \\
\text { итогом (\%) }\end{array}$ \\
\hline 1 & 6 & Р6 & 23,729 & 23,729 \\
\hline 2 & 1 & P1 & 20,467 & 44,196 \\
\hline 3 & 2 & P2 & 19,307 & 63,503 \\
\hline 4 & 3 & P3 & 14,347 & 77,850 \\
\hline 5 & 5 & P5 & 11,844 & 89,694 \\
\hline 6 & 4 & P4 & 10,306 & 100,000 \\
\hline
\end{tabular}

Из таблицы 8 видно, что наиболее сильное влияние на показатели качества молока оказывают параметры Р6 и Р1 ДПН, а наиболее низкое параметры P4 и Р5. 


\subsection{9. Степень детерминированности качества молока значениями параметров ДПН}

Степень детерминированности (обусловленности) класса в системе «Эйдос» количественно оценивается степенью вариабельности значений факторов (градаций описательных шкал) в колонке матрицы модели, соответствующей данному классу (таблица 9).

В данной работе у нас классами являются показатели качества коровьего молока (содержание в нем жира и белка), а значениями градаций описательных шкал - значения параметров ДПН.

На рисунке 33 мы видим Парето-кривую степени детерминированности классов значениями параметров ДПН нарастающим итогом.

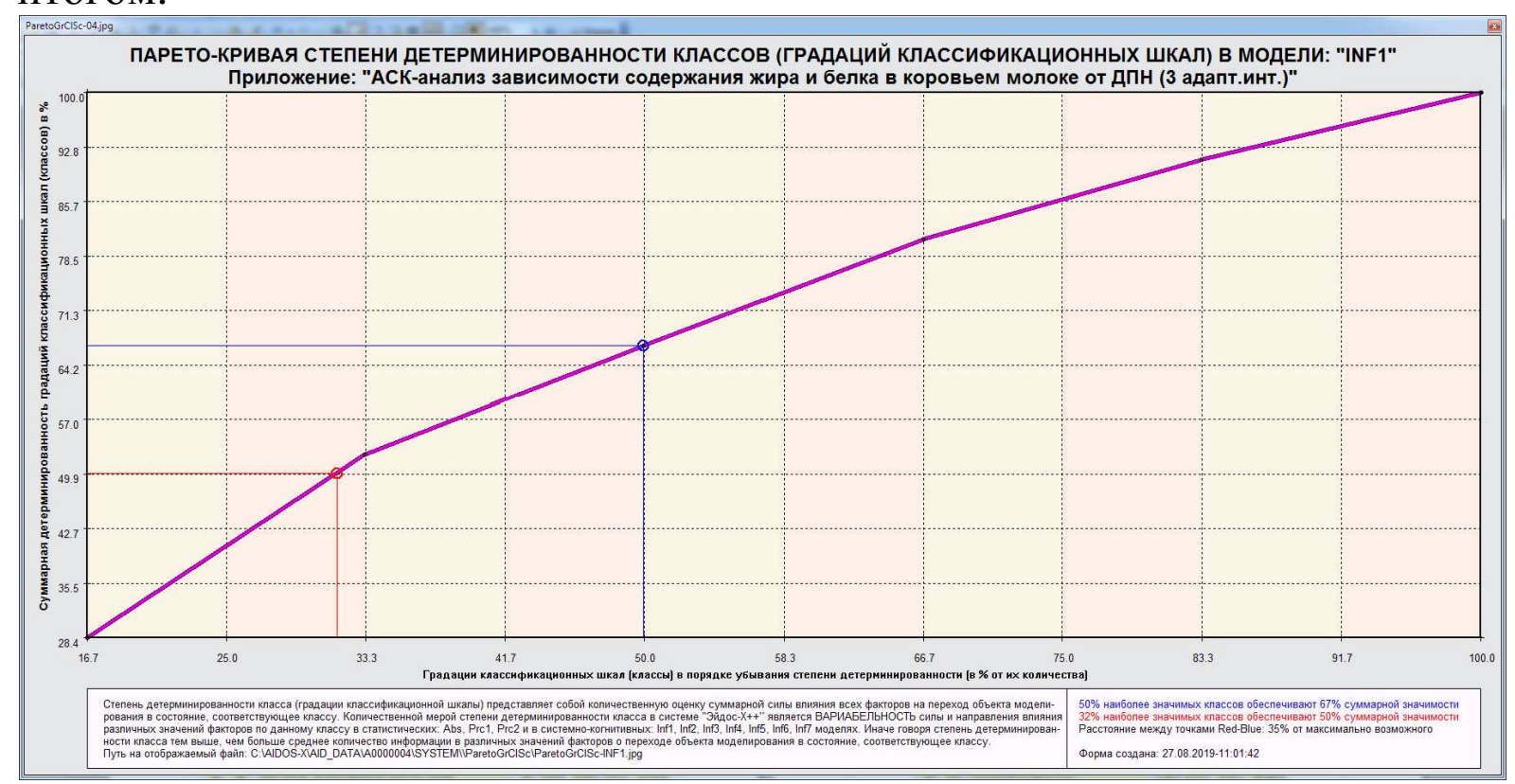

Рисунок 33. Парето-кривая степени детерминированности классов

Таблица 9 - Парето-таблица степеней детерминированности (обусловленности) классов (показателей качества коровьего молока)

в CК-модели INF1 с 3 адаптивными интервалами

\begin{tabular}{|c|c|c|c|c|c|}
\hline № & $\begin{array}{c}\text { Код } \\
\text { класса }\end{array}$ & Наименование класса & $\begin{array}{c}\text { Код } \\
\text { класс. } \\
\text { шкалы }\end{array}$ & $\begin{array}{c}\text { Степень } \\
\text { детермини- } \\
\text { рованности } \\
\text { класса (\%) }\end{array}$ & $\begin{array}{c}\text { Степень } \\
\text { детермини- } \\
\text { рованности } \\
\text { класса } \\
\text { нарастающим } \\
\text { итогом (\%) }\end{array}$ \\
\hline 1 & 3 & ЖИР, \%-3/3-\{4.3, 7.0\} & 1 & 28,357 & 28,357 \\
\hline 2 & 1 & ЖИР, \%-1/3-\{2.1, 3.7\} & 1 & 24,096 & 52,453 \\
\hline 3 & 4 & БЕЛОК, \%-1/3-\{2.8, 3.3\} & 2 & 14,285 & 66,738 \\
\hline 4 & 6 & БЕЛОК, \%-3/3-\{3.5, 4.5\} & 2 & 14,044 & 80,782 \\
\hline 5 & 2 & ЖИР, \%-2/3-\{3.7, 4.3\} & 1 & 10,429 & 91,212 \\
\hline 6 & 5 & БЕЛОК, \%-2/3-\{3.3, 3.5\} & 2 & 8,788 & 100,000 \\
\hline
\end{tabular}


Из таблицы 9 мы видим, что значения параметров ДПН наиболее сильно (жестко) детерминируют (обуславливают) высокое и низкое содержание жира в коровьем молоке. Высокое и низкое содержание белка детерминируется в два раза слабее, чем жира. А среднее и низкое содержание жира и белка детерминировано наиболее слабо.

При этом степень детерминированности наиболее и наименее детерминированных классов (максимальной жирности и среднего содержания белка) отличается примерно в три раза, что довольно существенно.

Чем выше степень детерминированности значения показателя качества коровьего молока значениями параметров ДПН, тем легче определить это качество по параметрам.

Степень детерминированности (обусловленности) всей классификационной шкалы является средним от степени детерминированности ее градаций, т.е. классов (таблица 10).

Таблица 10 - Классификационные шкалы, ранжированные по убыванию средней степени детерминированности их градаций в СК-модели INF1

\begin{tabular}{|c|c|l|c|c|}
\hline № & Код & Наименование показателя качества & 3начимость (\%) & $\begin{array}{c}\text { Значимость } \\
\text { нарастающим } \\
\text { итогом (\%) }\end{array}$ \\
\hline 1 & 1 & ЖИР, \% & 62,882 & 62,882 \\
\hline 2 & 2 & БЕЛОК, \% & 37,117 & 100,000 \\
\hline
\end{tabular}

Из таблицы 10 видно, что наиболее высокую степень детерминированности обуславливающими их факторами имеет содержание жира в коровьем молоке, а содержание белков детерминировано почти в 2 раза слабее.

Это значит, что жирность коровьего молока лучше определяется по параметрам ДПН, чем содержание в нем белка.

\subsubsection{0. Устойчивость содержания жира и белка В коровьем молоке от значений параметров ДПН}

Устойчивость зависимостей показателей качества коровьего молока от обуславливающих их значений параметров ДПН подразумевает непрерывность и монотонность этих зависимостей.

Непрерывность зависимостей показателей качества коровьего молока от обуславливающих их значений параметров ДПН означает, что малые изменения значений параметров ДПН детерминируют малые изменения показателей качества молока, а более значительные изменения значения параметров ДПН обуславливают и более существенные изменения показателей качества, т.е. степень изменения значений 
показателей качества молока соответствует степени изменения обуславливающчх их параметров ДПН.

Если непрерывность нарушается, то незначительное изменения значения параметров ДПН может привести как к малым, так и к значительным изменениям значений показателей качества коровьего молока, а большие изменения значений параметров ДПН могут оказать как сильное, так и незначительное влияние на изменение значений показателей качества.

Если в системе управления нарушается непрерывность управления, то это воспринимается как ее поломка, неисправность и непригодность для выполнения своей функции.

Hапример, если нарушается непрерывность зависимости тяги двигателя машины от степени нажатия педали газа, то при плавном увеличении газа машина будет не плавно разгоняться, а начнет дергаться и может вообще заглохнуть, как это бывает у новичков, которые еще не научились правильно трогаться с места.

Монотонность зависимостей показателей качества коровьего молока от значений параметров ДПН означает, что:

- если параметр ДПН способствует повышению качества коровьего молока, то увеличение значения параметра ДПН приводит к повышению показателя качества коровьего молока, т.е. между параметром ДПН и показателем качества молока наблюдается прямо-пропорциональная зависимость;

- если же параметр ДПН препятствуеm повышению качества коровьего молока, то увеличение значения параметра ДПН приводит к понижению показателя качества коровьего молока, т.е. между параметром ДПН и показателем качества молока наблюдается обратнопропорциональная зависимость.

Монотонность управления характерна для линейных систем управления и нарушается в нелинейных системах управления [21]. Система управления является линейной, если для нее выполняется принцип суперпозиции, т.е. результат совместного действия на нее совокупности факторов является суммой действий каждого из них по отдельности [21].

Если в системе управления нарушается монотонность управления, то это может приводить к тому, что при увеличении значения фактора результат может сначала увеличиваться практически пропорционально степени увеличения этого значения, затем скорость увеличения результата начинает уменьшаться и затем стабилизируется, а при дальнейшем увеличении значения фактора результат начинает уменьшаться вплоть до нуля или даже отрицательных значений (например, вместо прибыли получены убытки). Могут наблюдаться и другие нелинейные зависимости значения функции от значения аргумента. 
По сути, при нарушении монотонности управления меняется знак первой производной результата управления по значению фактора, нарушается знакоопределенность этой первой производной. Понятно, что немонотонные функции не являются непрерывными.

Принципиальный вид кривой влияния интенсивности фактора на результат в нелинейной системе при этом получается очень похожий у всех факторов (для примера на рисунке 34 показаны 3 из них):

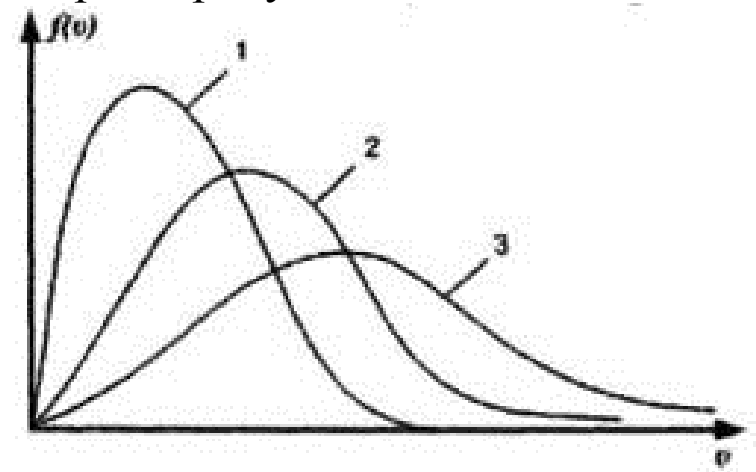

Рисунок 34. Принципиальный вид кривой влияния интенсивности фактора на нелинейный объект управления ${ }^{6}$.

Например, если по оси X показать интенсивность полива какой-либо конкретной культуры, а по Ү урожайность, то график на рисунке 31 можно интерпретировать таким образом, что при полном отсутствии полива урожайность будет минимальной, при его увеличении урожайность будет возрастать сначала быстро, потом все медленнее, затем достигнет максимума, а потом при дальнейшем увеличении полива она начнет уменьшаться пока опять не достигнет минимума (нуля, если культура не рис), когда все поле превратится в озеро.

Принципиально важно, что один $u$ тот же полив будет действовать по-разному при условии одновременного действия других факторов, причем при этом смещается точка оптимума, т.е. при действии других факторов оптимальный полив становится другой, в чем и проявляется нелинейность системь и взаимодействие факторов, нарушение для них приничип суперпозиции (кривые 1, 2, 3 на рисунке 34).

Нарушение монотонности управления может приводить к различным видам зависимостей результатов от значений управляющих факторов: это могут быть зависимости, типа показанных на рисунке 34; периодические зависимости (ярким примером является таблица Д.И.Менделеева, в которой свойства химических элементов изменяются

\footnotetext{
5 Это вызывает ассоциации с классическими понятием устойчивости управления по Ляпунову.

6 Источник рисунка: http://san-of-war2.narod.ru/fiziks/fiziks_image481.jpg На самом деле на рисунке показано распределение Максвелла молекул газа по скоростям при разных температурах. Удивительно, но подобный вид имеет влияние интенсивности различных факторов на различные нелинейные объекты управления
} 
периодически при линейном увеличении заряда ядра), а также сложные зависимости, в которых трудно найти какую-либо закономерность (напоминающие случайные).

Таким образом, у нас есть все основания разделить все значения параметров ДПН коровьего молока, действующие на содержание жира и белка в молоке, относящиеся к одной классификационной шкале, на три основные группы (рисунок 31):

1. Способствующие получению более высоких результатов.

2. Препятствующие получению более высоких результатов.

3. Действующие сложным и неоднозначным образом.

\section{7. Выводы}

Как показывает анализ результатов численного эксперимента предложенное и реализованное в системе «Эйдос» решение поставленных задач является вполне эффективным, что позволяет обоснованно утверждать, что цель работы достигнута, поставленная проблема решена.

В результате проделанной работы, с помощью системы «Эйдос» были созданы 3 статистические и 7 системно-когнитивных моделей, в которых непосредственно на основе эмпирических данных сформированы обобщенные образы классов по различным значениям показателей качества коровьего молока (содержанию в нем жира и белка), изучено влияние значений различных параметров ДПН на эти показатели качества, и, на основе этого, решены задачи квалиметрии, классификации и исследования моделируемой предметной области путем исследования ее модели.

Bсе это, по мнению авторов, является примером успешного применения когнитивных и информационных технологий для решения задач ветеринарии и может быть основанием для предложения нового научного направления: «Когнитивная ветеринария».

Со всеми моделями, созданными в данной статье, можно ознакомиться установив облачное Эйдос-приложение №154 в режиме 1.3 системы «Эйдос».

Автор благодарен доктору биологических наук профессору Андрею Георгиевичу Комаеву https://kubsau.ru/university/rectoratel 3 з предоставленную возможность опубликования данной статьи.

\section{Литература}

1. Милаёва И.В., Зайцев С.Ю., Довженко Н.А., Царьков Д.В., Царькова М.С. Регрессионная модель в анализе связи динамического поверхностного натяжения с содержанием жира и белка в молоке коров //Ветеринария, зоотехния и биотехнология. 2015. - №. 3. - С. 67-76. Источник: https://elibrary.ru/item.asp?id=23205136

2. Царьков Дмитрий Викторович, Воронина Оксана Александровна, Милаёва Ирина Валерьевна, Довженко Нина Александровна, Зайцев Сергей Юрьевич, Царькова Марина Сергеевна, Изобретение РФ № 0002600820: «Способ определения жира и белка 
в молоке по результатам динамического поверхностного натяжения» / Источник: https://edrid.ru/en/rid/217.015.7d23.html

3. Казаков В. Н. Межфазная тензиометрия и реометрия биологических жидкостей в терапевтической практике. Донецк: Мед. Университет, 2000. - 296 с.

4. Милаева И. В., Зарудная Е. Н., Зайцев С. Ю. и др. Межфазная тензиометрия в ветеринарии. М.: ФГОУ ВПО МГАВ-МиБ, 2010. - 110 с.

5. Зайцев С. Ю., Конопатов Ю. В.Биохимия животных. СПб.: Лань, 2005. - 384 с.

6. Zaitsev S. Yu., Milaeva I. V., Zarud-naya E. N., Maksimov V. I. (2011) Investigation of dynamic surface tension of biological liquids for animal blood diagnostics. Colloids and Surfaces A: Physicochem. Eng. Aspects, 383, 109-113.

7. Луценко Е.В. Синтез адаптивных интеллектуальных измерительных систем с применением АСК-анализа и системы «Эйдос» и системная идентификация в эконометрике, биометрии, экологии, педагогике, психологии и медицине / Е.В. Луценко // Политематический сетевой электронный научный журнал Кубанского государственного аграрного университета (Научный журнал КубГАУ) [Электронный pесурс]. - Краснодар: КубГАУ, 2016. - №02(116). С. 1 - 60. - IDA [article ID]: 1161602001. - Режим доступа: http://ej.kubagro.ru/2016/02/pdf/01.pdf, 3,75 у.п.л.

8. Луценко Е.В. Автоматизированный системно-когнитивный анализ в управлении активными объектами (системная теория информации и ее применение в исследовании экономических, социально-психологических, технологических и организационно-технических систем): Монография (научное издание). - Краснодар: КубГАУ. 2002. - 605 c. http://elibrary.ru/item.asp?id=18632909

9. Луценко Е.В. Метризация измерительных шкал различных типов и совместная сопоставимая количественная обработка разнородных факторов в системнокогнитивном анализе и системе «Эйдос» / Е.В. Луценко // Политематический сетевой электронный научный журнал Кубанского государственного аграрного университета (Научный журнал КубГАУ) [Электронный ресурс]. - Краснодар: КубГАУ, 2013. №08(092). С. 859 - 883. - IDA [article ID]: 0921308058. - Режим доступа: http://ej.kubagro.ru/2013/08/pdf/58.pdf, 1,562 у.п.л.

10. Луценко Е.В. Инвариантное относительно объемов данных нечеткое мультиклассовое обобщение F-меры достоверности моделей Ван Ризбергена в АСКанализе и системе «Эйдос» / Е.В. Луценко // Политематический сетевой электронный научный журнал Кубанского государственного аграрного университета (Научный журнал КубГАУ) [Электронный ресурс]. - Краснодар: КубГАУ, 2017. - №02(126). С. 1 - 32. - IDA [article ID]: 1261702001. - Режим доступа: http://ej.kubagro.ru/2017/02/pdf/01.pdf, 2 у.п.л.

11. Луценко Е.В. Количественный автоматизированный SWOT- и PEST-анализ средствами АСК-анализа и интеллектуальной системы «Эйдос-Х++» / Е.В. Луценко // Политематический сетевой электронный научный журнал Кубанского государственного аграрного университета (Научный журнал КубГАУ) [Электронный peсурс]. - Краснодар: КубГАУ, 2014. - №07(101). С. 1367 - 1409. - IDA [article ID]: 1011407090. - Режим доступа: http://ej.kubagro.ru/2014/07/pdf/90.pdf, 2,688 у.п.л.

12. Луценко Е.В. Метод когнитивной кластеризации или кластеризация на основе знаний (кластеризация в системно-когнитивном анализе и интеллектуальной системе «Эйдос») / Е.В. Луценко, В.Е. Коржаков // Политематический сетевой электронный научный журнал Кубанского государственного аграрного университета (Научный журнал КубГАУ) [Электронный ресурс]. - Краснодар: КубГАУ, 2011. - №07(071). С. 528 - 576. - Шифр Информрегистра: 042110001210253, IDA [article ID]: 0711107040. Режим доступа: http://ej.kubagro.ru/2011/07/pdf/40.pdf, 3,062 у.П.л. 
13. Луценко Е.В. Системная теория информации и нелокальные интерпретируемые нейронные сети прямого счета / Е.В. Луценко // Политематический сетевой электронный научный журнал Кубанского государственного аграрного университета (Научный журнал КубГАУ) [Электронный ресурс]. - Краснодар: КубГАУ, 2003. - №01(001). С. 79 - 91. - IDA [article ID]: 0010301011. - Режим доступа: http://ej.kubagro.ru/2003/01/pdf/11.pdf, 0,812 у.п.л.

14. Орлов А.И., Луценко Е.В. Системная нечеткая интервальная математика. Монография (научное издание). - Краснодар, КубГАУ. 2014. - 600 с. ISBN 978-594672-757-0. http://elibrary.ru/item.asp?id=21358220

15. Луценко Е.В., Открытая масштабируемая интерактивная интеллектуальная online среда «Эйдос» («Эйдоc-online»). Свид. РосПатента РФ на программу для ЭВМ, Заявка № 2017618053 от 07.08.2017, Гос.рег.№ 2017661153, зарегистр. 04.10.2017. Режим доступа: http://lc.kubagro.ru/aidos/2017661153.jpg, 2 у.п.л.

16. Луценко Е.В. Открытая масштабируемая интерактивная интеллектуальная online среда для обучения и научных исследований на базе АСК-анализа и системы «Эйдос» / Е.В. Луценко // Политематический сетевой электронный научный журнал Кубанского государственного аграрного университета (Научный журнал КубГАУ) [Электронный ресурс]. - Краснодар: КубГАУ, 2017. - №66(130). С. 1 - 55. - IDA [article ID]: 1301706001. - Режим доступа: http://ej.kubagro.ru/2017/06/pdf/01.pdf, 3,438 у.п.л. http://lc.kubagro.ru/aidos/Presentation_Aidos-online.pdf

17. Луценко Е.В. Проблемы и перспективы теории и методологии научного познания и автоматизированный системно-когнитивный анализ как автоматизированный метод научного познания, обеспечивающий содержательное феноменологическое моделирование / Е.В. Луценко // Политематический сетевой электронный научный журнал Кубанского государственного аграрного университета (Научный журнал КубГАУ) [Электронный ресурс]. - Краснодар: КубГАУ, 2017. №03(127). С. 1 - 60. - IDA [article ID]: 1271703001. - Режим доступа: http://ej.kubagro.ru/2017/03/pdf/01.pdf, 3,75 у.п.л.

18. Луценко Е.В. Универсальная автоматизированная система распознавания образов "Эйдос" (версия 4.1).-Краснодар: КЮИ МВД РФ, 1995.- 76с. http://elibrary.ru/item.asp?id=18630282

19. Луценко Е.В. Универсальная когнитивная аналитическая система «Эйдос". Монография (научное издание). - Краснодар, КубГАУ. 2014. - 600 с. ISBN 978-594672-830-0. http://elibrary.ru/item.asp?id=22401787

20. Луценко Е. В., Лойко В. И., Лаптев В. Н. Системы представления и приобретения знаний : учеб. пособие / Е. В. Луценко, В. И. Лойко, В. Н. Лаптев. Краснодар : Экоинвест, 2018. - 513 с. ISBN 978-5-94215-415-8. https://elibrary.ru/item.asp?id=35641755

21. Луценко Е.В. Моделирование сложных многофакторных нелинейных объектов управления на основе фрагментированных зашумленных эмпирических данных большой размерности в системно-когнитивном анализе и интеллектуальной системе «Эйдос-Х++» / Е.В. Луценко, В.Е. Коржаков // Политематический сетевой электронный научный журнал Кубанского государственного аграрного университета (Научный журнал КубГАУ) [Электронный ресурс]. - Краснодар: КубГАУ, 2013. - №07(091). С. $164-188 . \quad-\quad$ IDA [article ID]: 0911307012. доступа: http://ej.kubagro.ru/2013/07/pdf/12.pdf, 1,562 у.п.л.

\section{Literatura}

1. Milayova I.V., Zajcev S.Yu., Dovzhenko N.A., Czar`kov D.V., Czar`kova M.S. Regressionnaya model` $\mathrm{v}$ analize svyazi dinamicheskogo poverxnostnogo natyazheniya 
s soderzhaniem zhira i belka $\mathrm{v}$ moloke korov //Veterinariya, zootexniya i biotexnologiya. 2015. - №. 3. - S. 67-76. Istochnik: https://elibrary.ru/item.asp?id=23205136

2. Czarkov Dmitrij Viktorovich, Voronina Oksana Aleksandrovna, Milayova Irina Valer`evna, Dovzhenko Nina Aleksandrovna, Zajcev Sergej Yur`evich, Czar`kova Marina Sergeevna, Izobretenie RF № 0002600820: «Sposob opredeleniya zhira i belka v moloke po rezul tatam dinamicheskogo poverxnostnogo natyazheniya» / Istochnik: https://edrid.ru/en/rid/217.015.7d23.html

3. Kazakov V. N. Mezhfaznaya tenziometriya i reometriya biologicheskix zhidkostej v terapevticheskoj praktike. Doneczk: Med. Universitet, 2000. - 296 s.

4. Milaeva I. V., Zarudnaya E. N., Zajcev S. Yu. i dr. Mezhfaznaya tenziometriya v veterinarii. M.: FGOU VPO MGAV-MiB, 2010. - $110 \mathrm{s.}$

5. Zajcev S. Yu., Konopatov Yu. V.Bioximiya zhivotny`x. SPb.: Lan`, 2005. $384 \mathrm{~s}$.

6. Zaitsev S. Yu., Milaeva I. V., Zarud-naya E. N., Maksimov V. I. (2011) Investigation of dynamic surface tension of biological liquids for animal blood diagnostics. Colloids and Surfaces A: Physicochem. Eng. Aspects, 383, 109-113.

7. Lucenko E.V. Sintez adaptivny`x intellektual`ny`x izmeritel`ny`x sistem s primeneniem ASK-analiza i sistemy` «E`jdos» i sistemnaya identifikaciya v e`konometrike, biometrii, e`kologii, pedagogike, psixologii i medicine / E.V. Lucenko // Politematicheskij setevoj e`lektronny`j nauchny`j zhurnal Kubanskogo gosudarstvennogo agrarnogo universiteta (Nauchny j zhurnal KubGAU) [E`lektronny`j resurs]. - Krasnodar: KubGAU, 2016. - №02(116). S. 1 - 60. - IDA [article ID]: 1161602001. - Rezhim dostupa: http://ej.kubagro.ru/2016/02/pdf/01.pdf, 3,75 u.p.l.

8. Lucenko E.V. Avtomatizirovanny`j sistemno-kognitivny`j analiz v upravlenii aktivny`mi ob“ektami (sistemnaya teoriya informacii $\mathrm{i}$ ee primenenie $\mathrm{v}$ issledovanii e`konomicheskix, social no-psixologicheskix, texnologicheskix i organizacionnotexnicheskix sistem): Monografiya (nauchnoe izdanie). - Krasnodar: KubGAU. 2002. - 605 s. http://elibrary.ru/item.asp?id=18632909

9. Lucenko E.V. Metrizaciya izmeritel`ny`x shkal razlichny`x tipov i sovmestnaya sopostavimaya kolichestvennaya obrabotka raznorodny`x faktorov $\mathrm{v}$ sistemnokognitivnom analize i sisteme «E’jdos» / E.V. Lucenko // Politematicheskij setevoj e`lektronny`j nauchny`j zhurnal Kubanskogo gosudarstvennogo agrarnogo universiteta (Nauchny`j zhurnal KubGAU) [E`lektronny`j resurs]. - Krasnodar: KubGAU, 2013. №08(092). S. 859 - 883. - IDA [article ID]: 0921308058. - Rezhim dostupa: http://ej.kubagro.ru/2013/08/pdf/58.pdf, 1,562 u.p.l.

10. Lucenko E.V. Invariantnoe otnositel`no ob“emov danny`x nechetkoe mul tiklassovoe obobshhenie F-mery` dostovernosti modelej Van Rizbergena v ASK-analize i sisteme «E`jdos» / E.V. Lucenko // Politematicheskij setevoj e`lektronny`j nauchny`j zhurnal Kubanskogo gosudarstvennogo agrarnogo universiteta (Nauchny j zhurnal KubGAU) [E`lektronny`j resurs]. - Krasnodar: KubGAU, 2017. - №02(126). S. 1 - 32. - IDA [article ID]: 1261702001. - Rezhim dostupa: http://ej.kubagro.ru/2017/02/pdf/01.pdf, 2 u.p.1.

11. Lucenko E.V. Kolichestvenny’j avtomatizirovanny’j SWOT- i PEST-analiz sredstvami ASK-analiza i intellektual`noj sistemy` «E`jdos-X++» / E.V. Lucenko // Politematicheskij setevoj e`lektronny`j nauchny`j zhurnal Kubanskogo gosudarstvennogo agrarnogo universiteta (Nauchny`j zhurnal KubGAU) [E`lektronny`j resurs]. - Krasnodar: KubGAU, 2014. - №07(101). S. 1367 - 1409. - IDA [article ID]: 1011407090. - Rezhim dostupa: http://ej.kubagro.ru/2014/07/pdf/90.pdf, 2,688 u.p.1.

12. Lucenko E.V. Metod kognitivnoj klasterizacii ili klasterizaciya na osnove znanij (klasterizaciya v sistemno-kognitivnom analize i intellektual noj sisteme «E`jdos») / E.V. Lucenko, V.E. Korzhakov // Politematicheskij setevoj e`lektronny`j nauchny`j zhurnal 
Kubanskogo gosudarstvennogo agrarnogo universiteta (Nauchny`j zhurnal KubGAU) [E`lektronny`j resurs]. - Krasnodar: KubGAU, 2011. - №07(071). S. 528 - 576. - Shifr Informregistra: 0421100012 \0253, IDA [article ID]: 0711107040. - Rezhim dostupa: http://ej.kubagro.ru/2011/07/pdf/40.pdf, 3,062 u.p.1.

13. Lucenko E.V. Sistemnaya teoriya informacii i nelokal`ny`e interpretiruemy`e nejronny`e seti pryamogo scheta / E.V. Lucenko // Politematicheskij setevoj e`lektronny`j nauchny j zhurnal Kubanskogo gosudarstvennogo agrarnogo universiteta (Nauchny j zhurnal KubGAU) [E`lektronny`j resurs]. - Krasnodar: KubGAU, 2003. - №01(001). S. 79 - 91. IDA [article ID]: 0010301011. - Rezhim dostupa: http://ej.kubagro.ru/2003/01/pdf/11.pdf, 0,812 u.p.l.

14. Orlov A.I., Lucenko E.V. Sistemnaya nechetkaya interval 'naya matematika. Monografiya (nauchnoe izdanie). - Krasnodar, KubGAU. 2014. - 600 s. ISBN 978-5-94672757-0. http://elibrary.ru/item.asp?id=21358220

15. Lucenko E.V., Otkry` taya masshtabiruemaya interaktivnaya intellektual `naya on-line sreda «E`jdos» («E`jdos-online»). Svid. RosPatenta RF na programmu dlya E`VM, Zayavka № 2017618053 ot 07.08.2017, Gos.reg.№ 2017661153, zaregistr. 04.10.2017. Rezhim dostupa: http://lc.kubagro.ru/aidos/2017661153.jpg, 2 u.p.l.

16. Lucenko E.V. Otkry taya masshtabiruemaya interaktivnaya intellektual naya on-line sreda dlya obucheniya i nauchny`x issledovanij na baze ASK-analiza i sistemy` «E`jdos» / E.V. Lucenko // Politematicheskij setevoj e`lektronny`j nauchny`j zhurnal Kubanskogo gosudarstvennogo agrarnogo universiteta (Nauchny`j zhurnal KubGAU) [E`lektronny`j resurs]. - Krasnodar: KubGAU, 2017. - №66(130). S. 1 - 55. - IDA [article ID]: 1301706001. - Rezhim dostupa: http://ej.kubagro.ru/2017/06/pdf/01.pdf, 3,438 u.p.l. http://lc.kubagro.ru/aidos/Presentation_Aidos-online.pdf

17. Lucenko E.V. Problemy`i perspektivy` teorii i metodologii nauchnogo poznaniya i avtomatizirovanny`j sistemno-kognitivny`j analiz kak avtomatizirovanny`j metod nauchnogo poznaniya, obespechivayushhij soderzhatel'noe fenomenologicheskoe modelirovanie / E.V. Lucenko // Politematicheskij setevoj e`lektronny`j nauchny`j zhurnal Kubanskogo gosudarstvennogo agrarnogo universiteta (Nauchny`j zhurnal KubGAU) [E`lektronny`j resurs]. - Krasnodar: KubGAU, 2017. - №03(127). S. 1 - 60. - IDA [article ID]: 1271703001. - Rezhim dostupa: http://ej.kubagro.ru/2017/03/pdf/01.pdf, 3,75 u.p.1.

18. Lucenko E.V. Universal naya avtomatizirovannaya sistema raspoznavaniya obrazov "E`jdos" (versiya 4.1).-Krasnodar: KYuI MVD RF, 1995.- 76s. http://elibrary.ru/item.asp?id=18630282

19. Lucenko E.V. Universal naya kognitivnaya analiticheskaya sistema «E`jdos". Monografiya (nauchnoe izdanie). - Krasnodar, KubGAU. 2014. - 600 s. ISBN 978-5-94672830-0. http://elibrary.ru/item.asp?id=22401787

20. Lucenko E. V., Lojko V. I., Laptev V. N. Sistemy' predstavleniya i priobreteniya znanij : ucheb. posobie / E. V. Lucenko, V. I. Lojko, V. N. Laptev. - Krasnodar : E`koinvest, 2018. $\quad$ - $\quad 513 \quad$ s. $\quad$ ISBN $978-5-94215-415-8$. https://elibrary.ru/item.asp?id=35641755

21. Lucenko E.V. Modelirovanie slozhny`x mnogofaktorny`x nelinejny`x ob“ektov upravleniya na osnove fragmentirovanny`x zashumlenny`x e`mpiricheskix danny`x bol `shoj razmernosti v sistemno-kognitivnom analize i intellektual `noj sisteme «E`jdos-X++» / E.V. Lucenko, V.E. Korzhakov // Politematicheskij setevoj e`lektronny`j nauchny`j zhurnal Kubanskogo gosudarstvennogo agrarnogo universiteta (Nauchny`j zhurnal KubGAU) [E`lektronny`j resurs]. - Krasnodar: KubGAU, 2013. - №07(091). S. 164 - 188. - IDA [article ID]: 0911307012. - Rezhim dostupa: http://ej.kubagro.ru/2013/07/pdf/12.pdf, 1,562 u.p.l. 